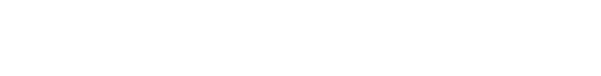

\section{فيزعبالهناح ألوعمـ"}

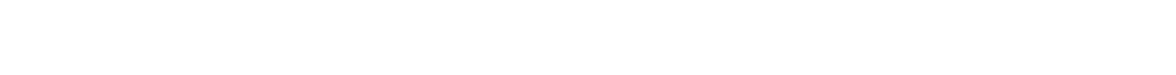

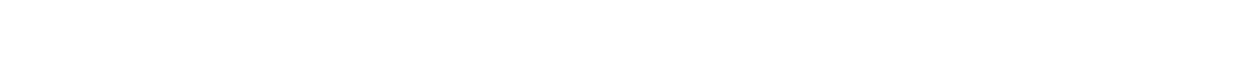

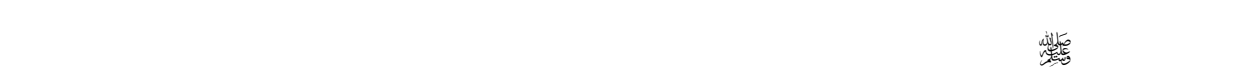

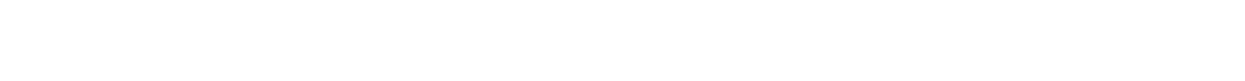

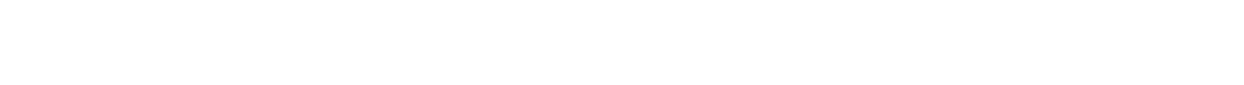

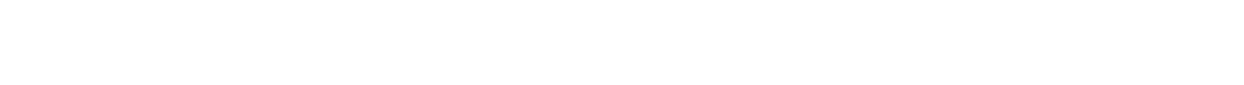

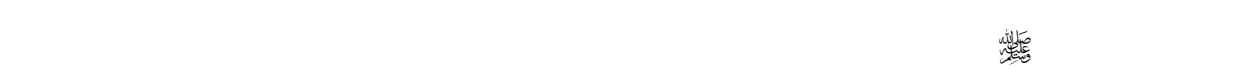

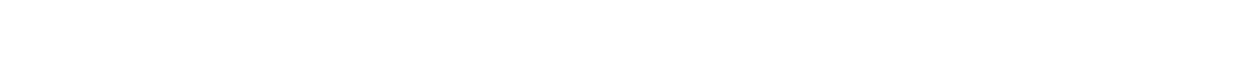

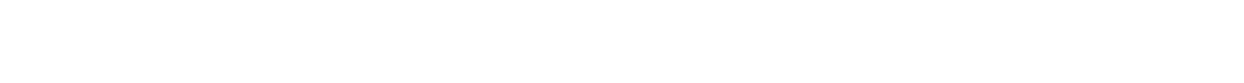

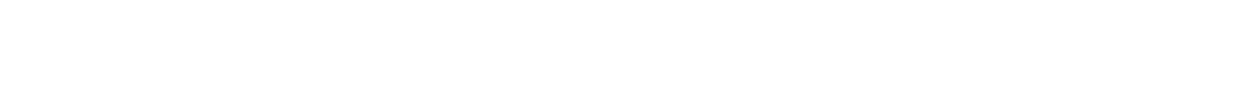

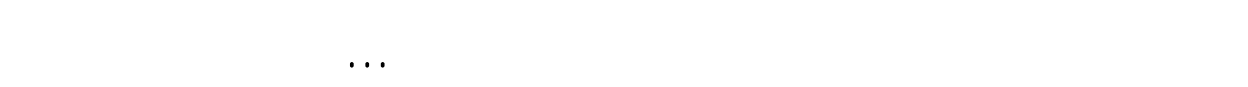

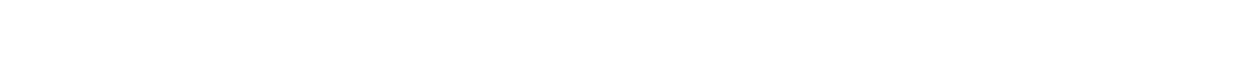

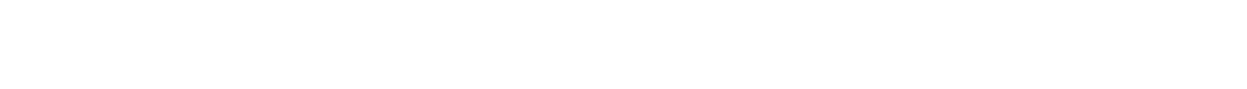

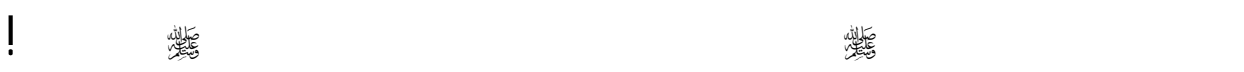

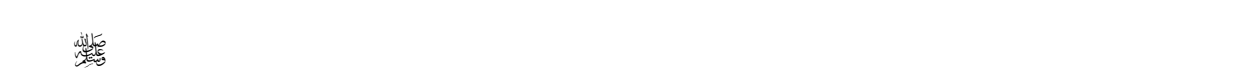

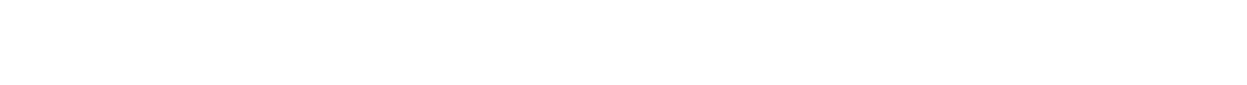




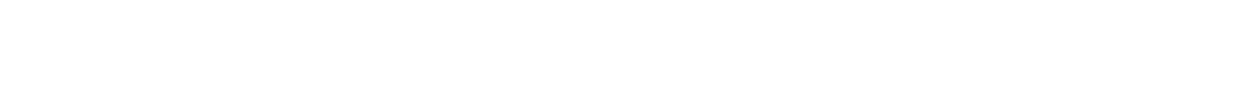

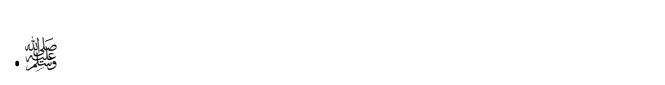

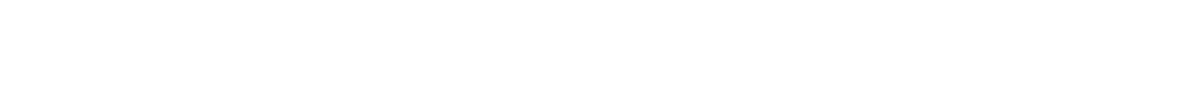

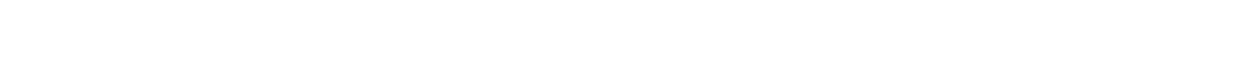

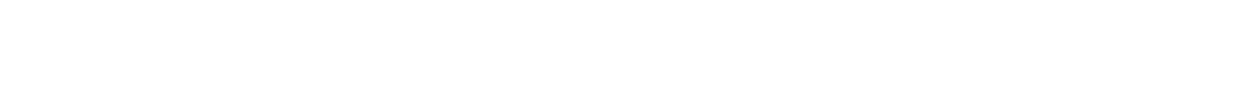

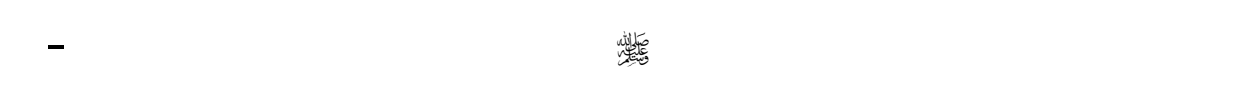

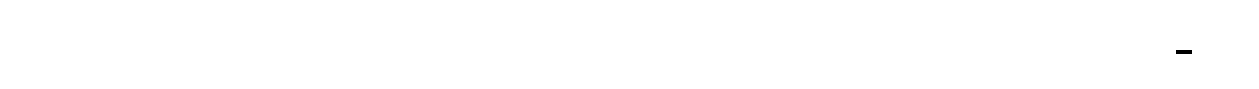

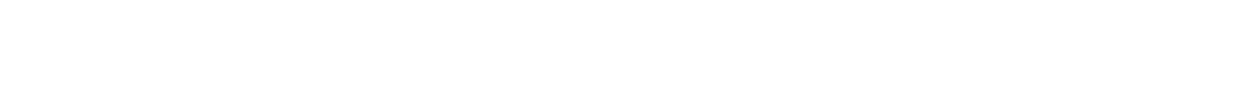

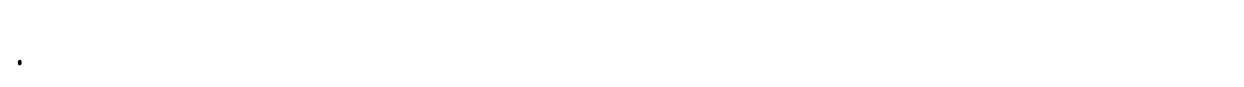

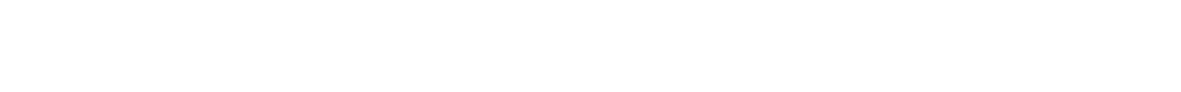

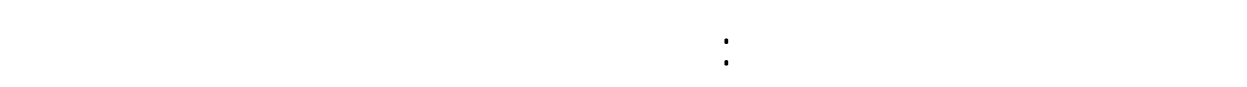

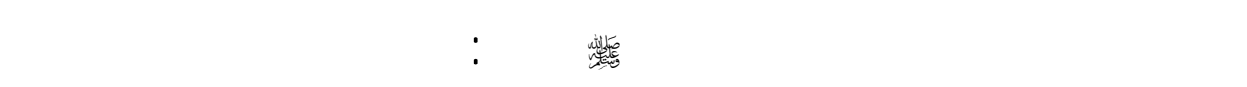

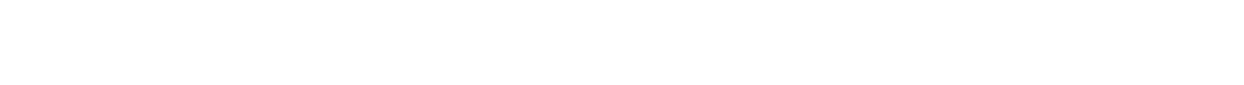

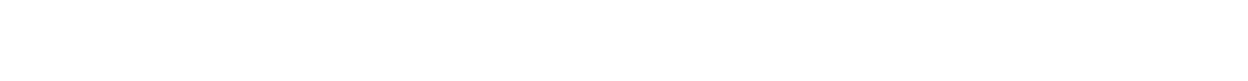

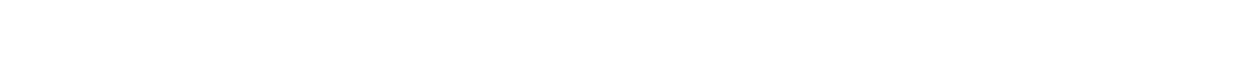

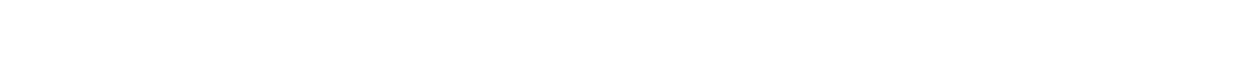

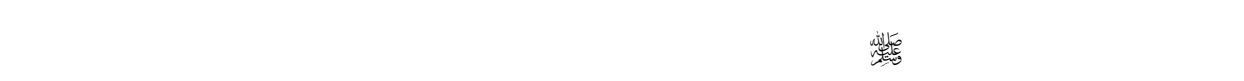

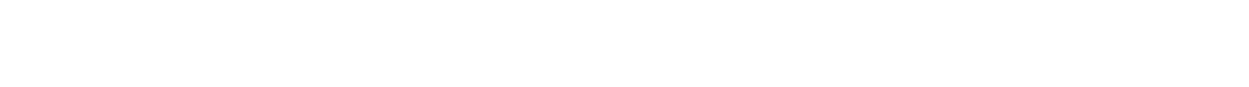
الكتلب والمة.

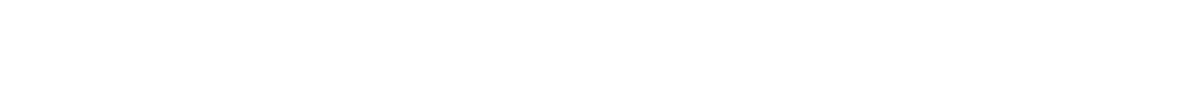

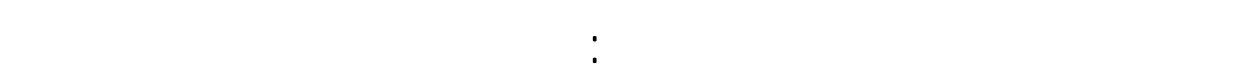

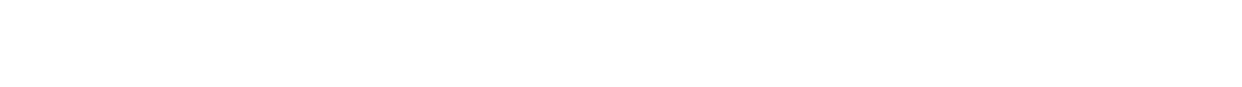

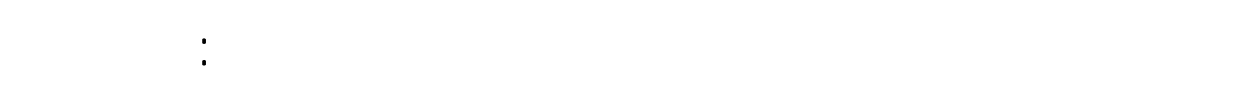

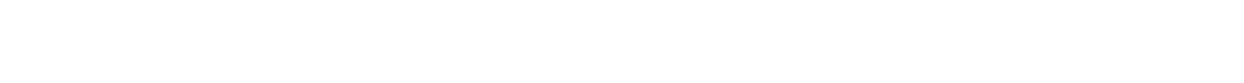




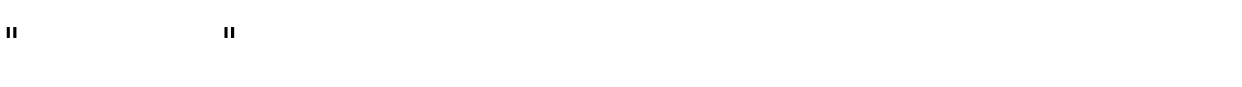

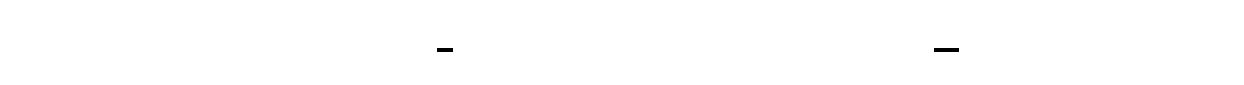

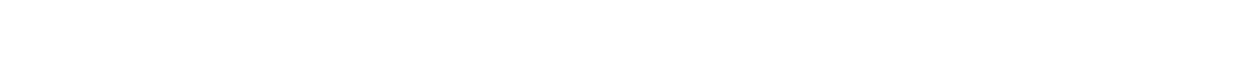

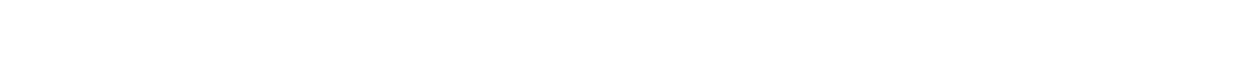

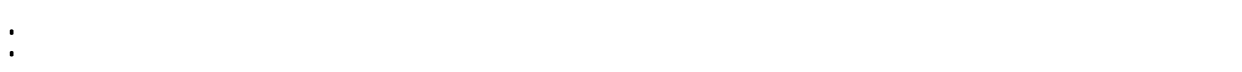

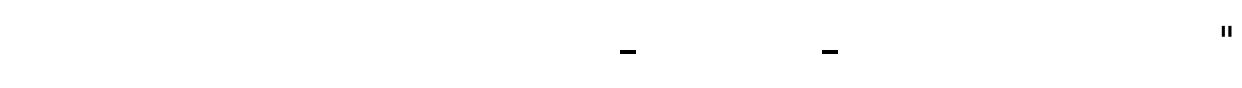

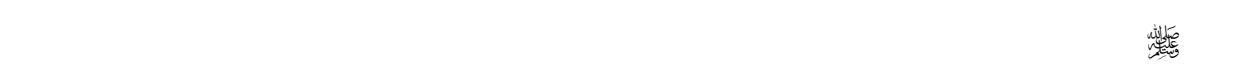

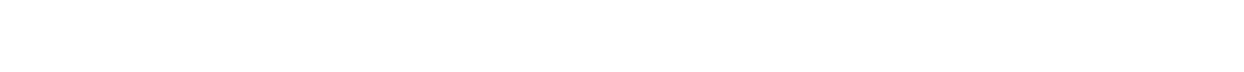

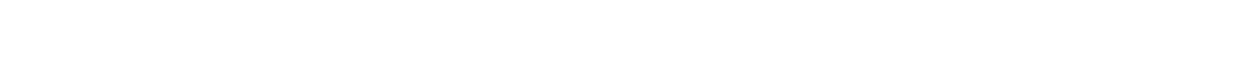

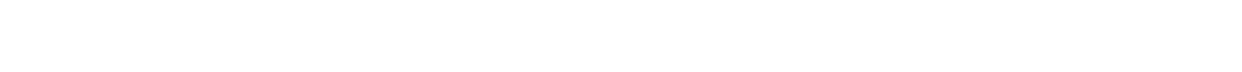

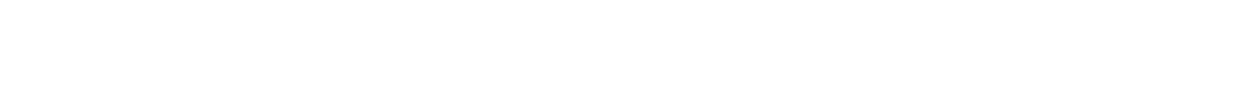

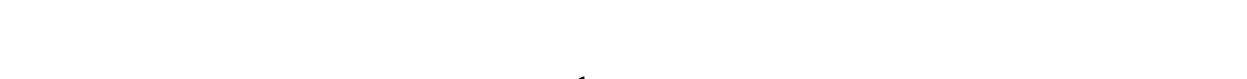

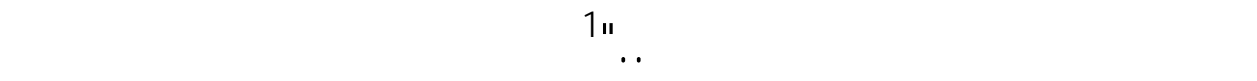

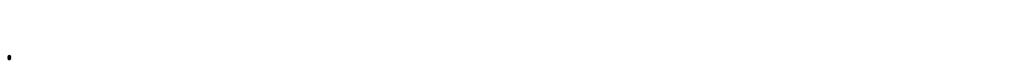

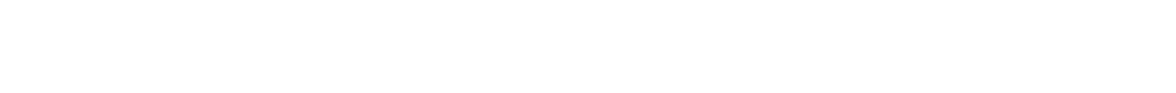

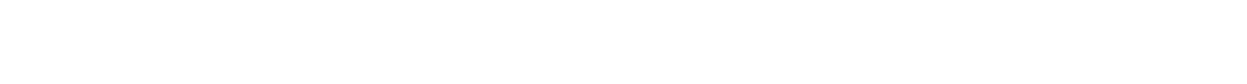

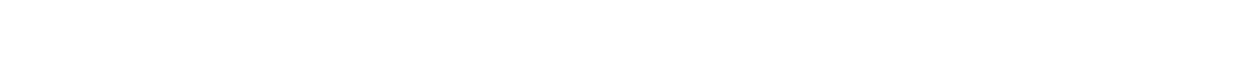

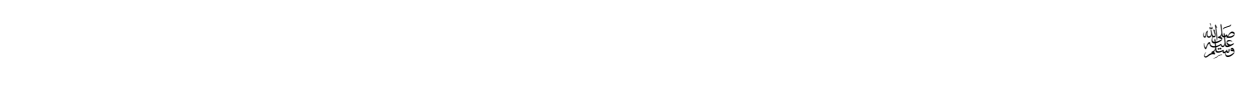

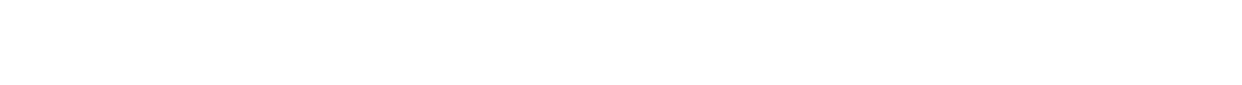

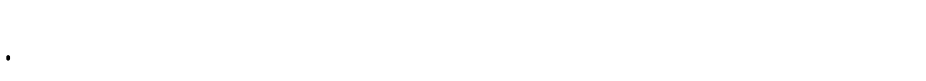

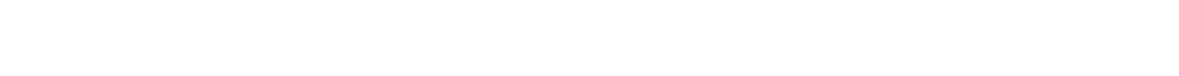

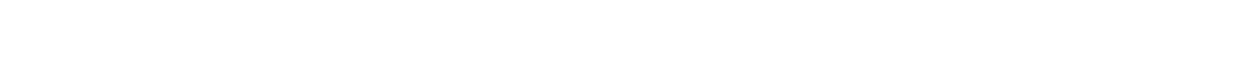

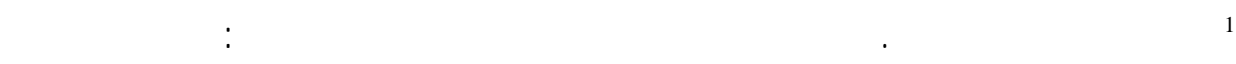
990م،ط2.ص.56. 


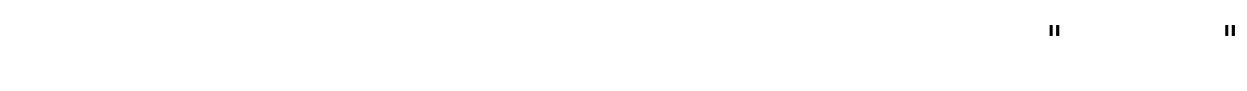

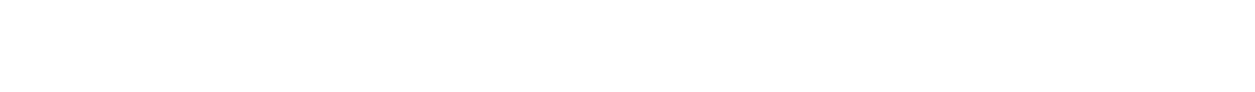

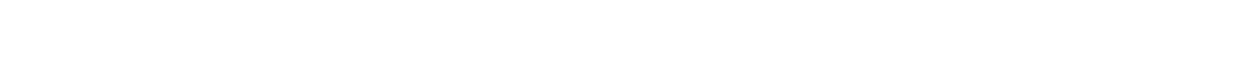

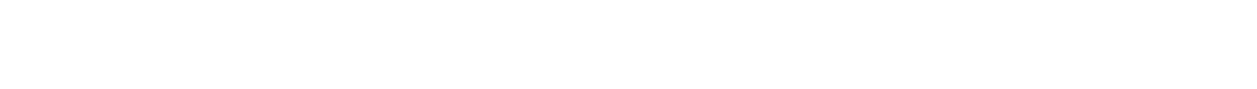

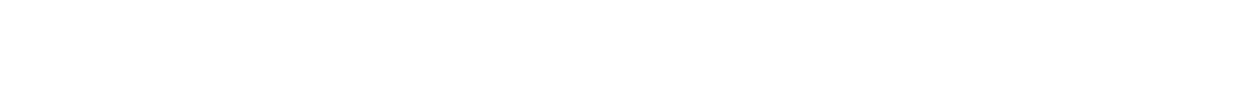

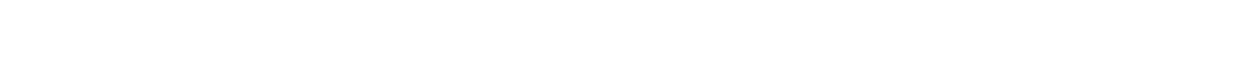

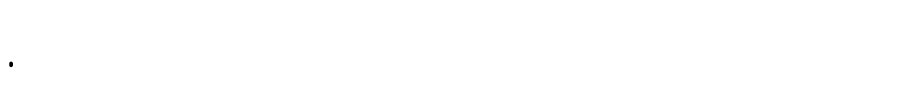

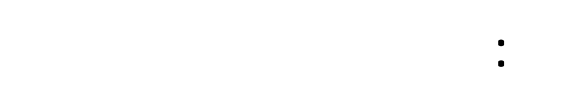

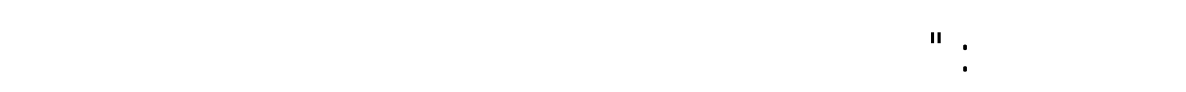

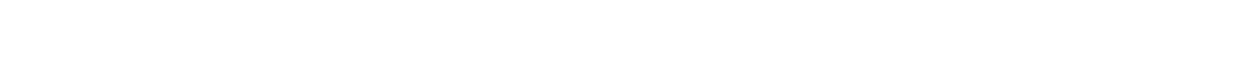

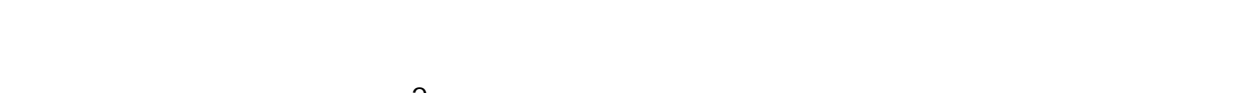

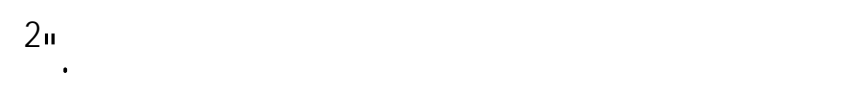

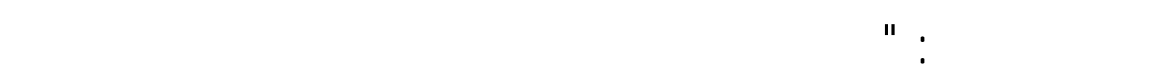

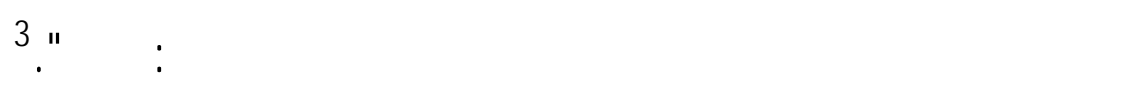

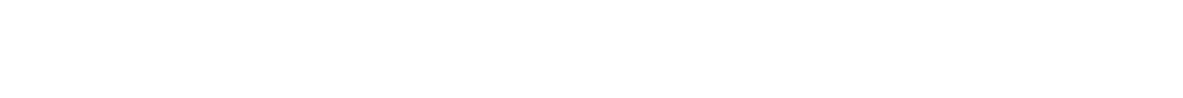

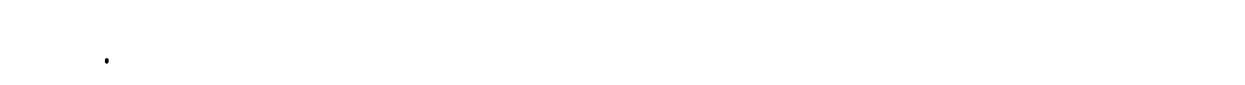

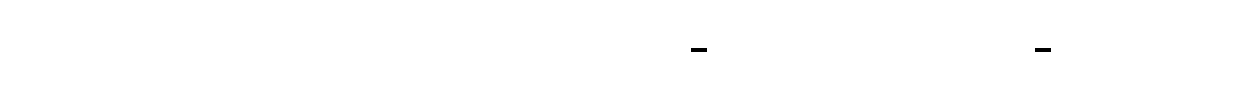

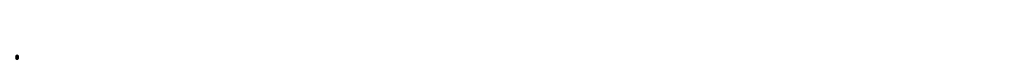

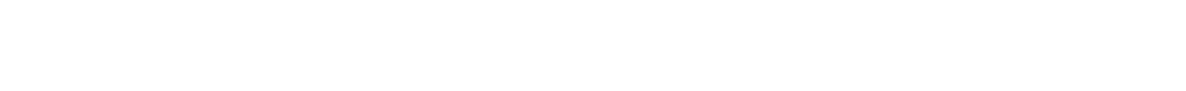

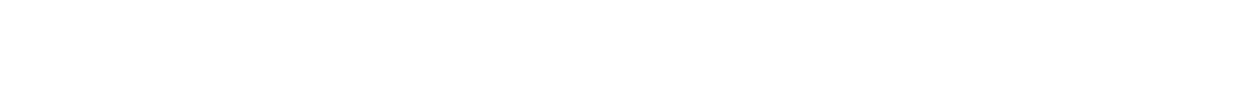

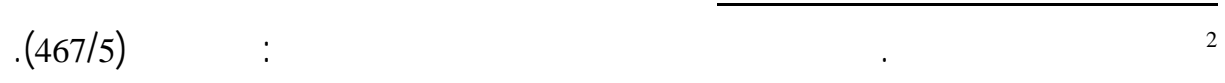

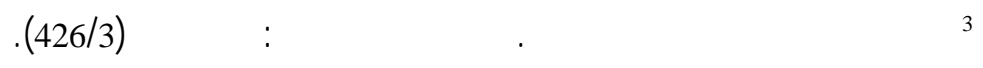




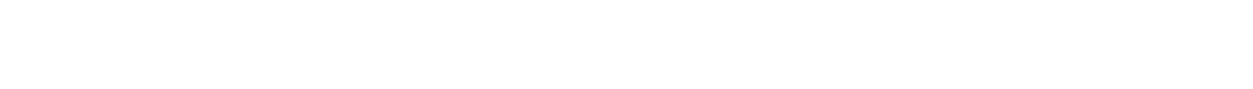

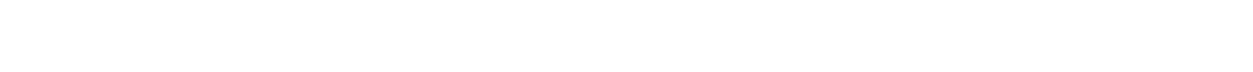

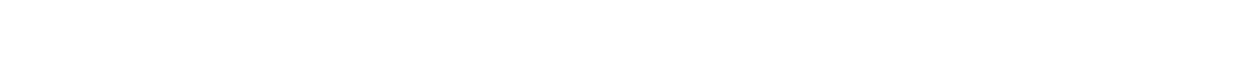

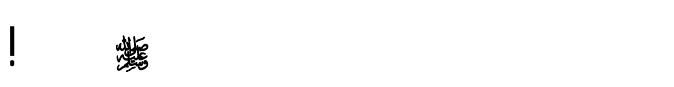

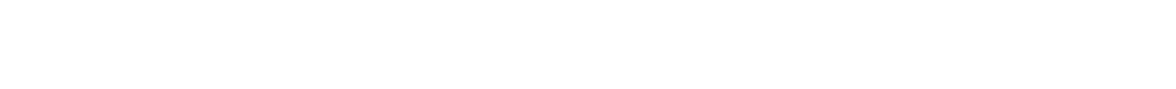

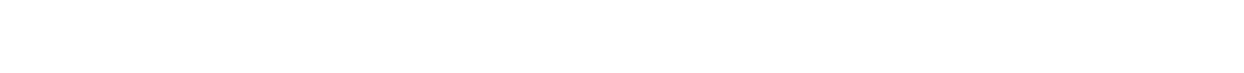

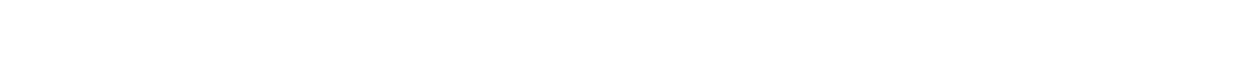

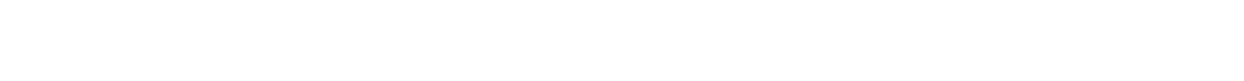
إلـاسطل ال

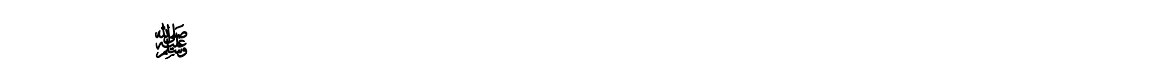

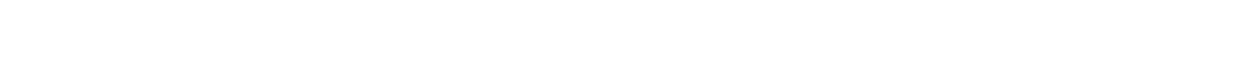

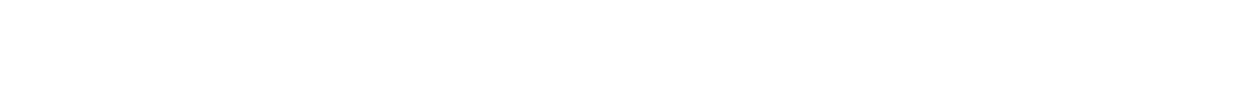

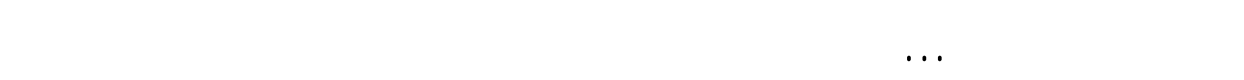

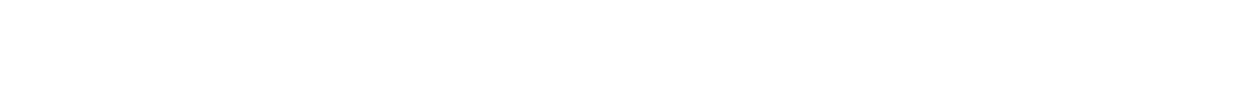

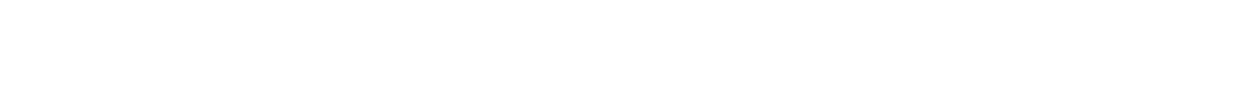
.

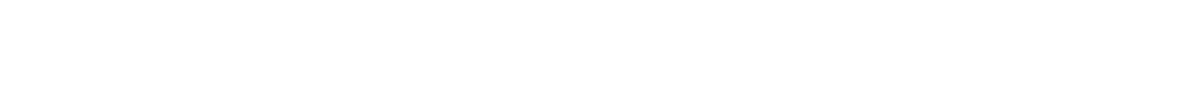

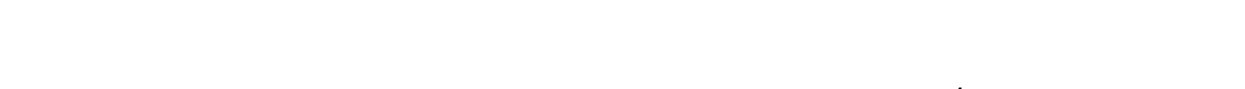

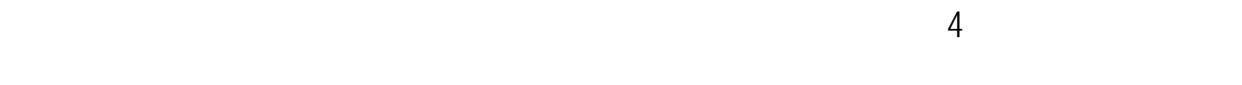

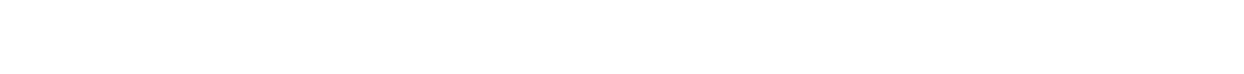
على يدي لني الأكفال، حينماقل : "علم رلية الهيث علم ينعرف مه أنواع الرولية

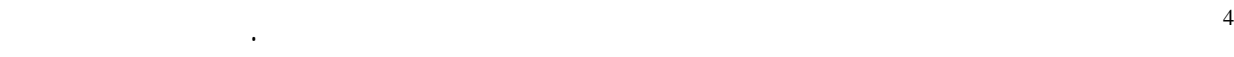

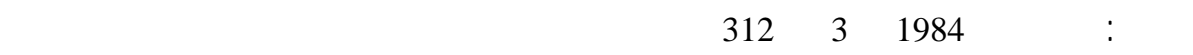

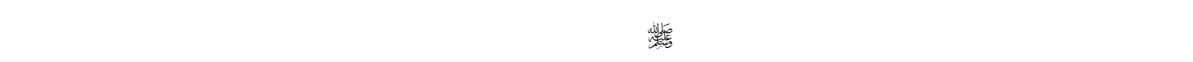

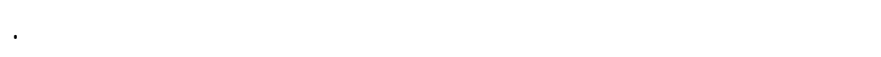


وأحكلمها، وشروط الرواة، وأسنف المرويت، ولستخراج معانيها، وطتاج إلـ ما

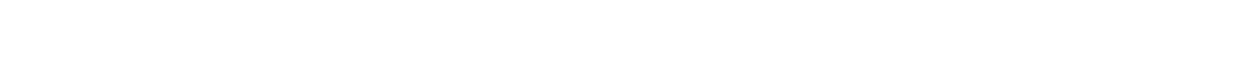

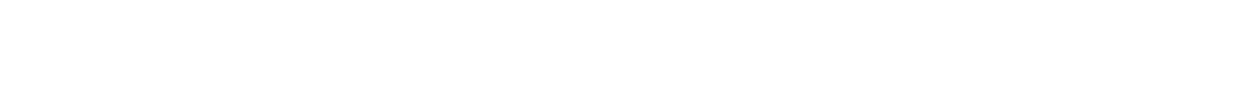

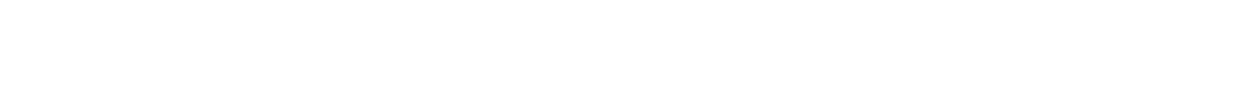

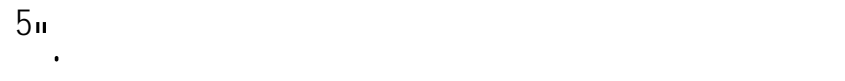

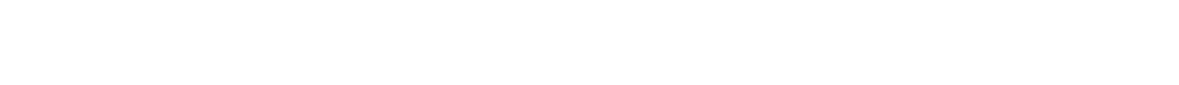

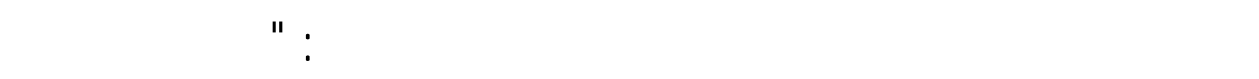
رولة."

قول الشبخ تقي الدن: "ألا الهله بالدراية فيهرف عه حقية الرولية وثروطها

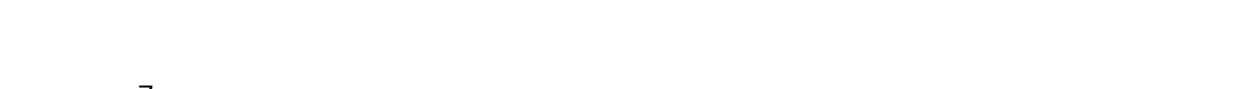

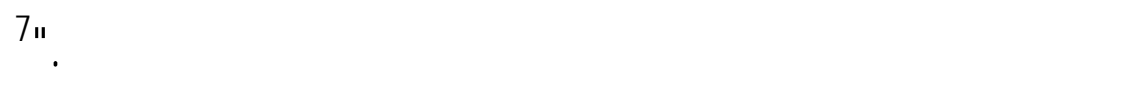

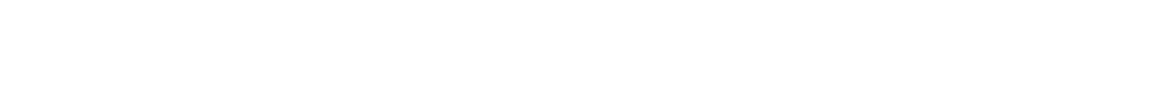

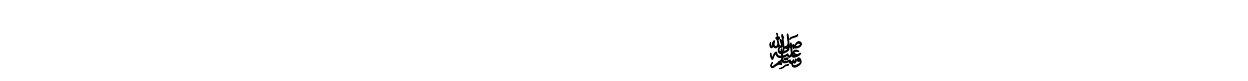

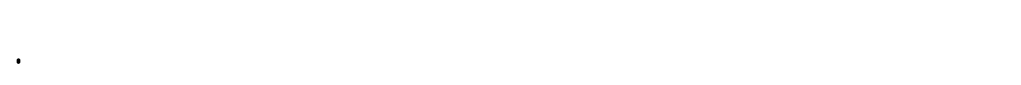

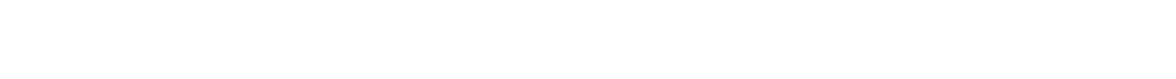

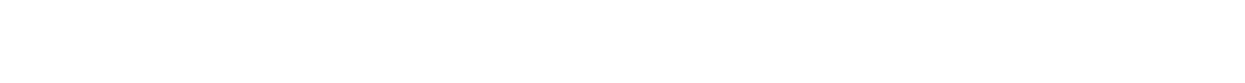

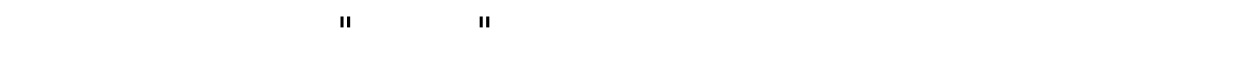

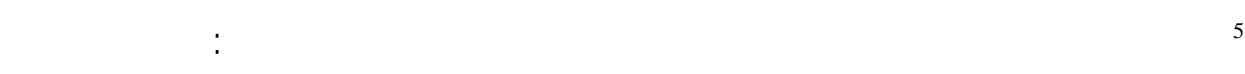

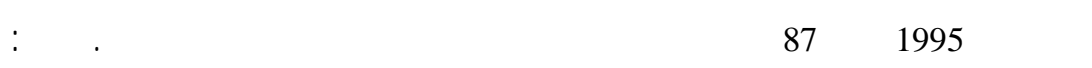

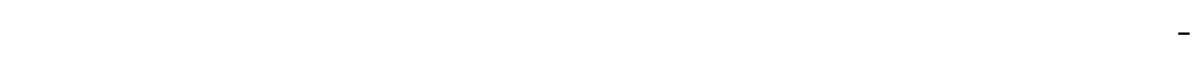

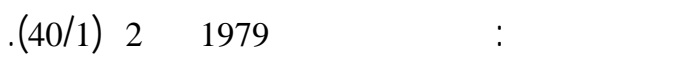

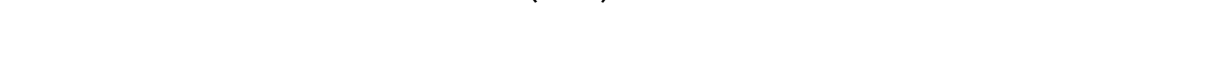
إلمنوة: آلكنبة السلفية، 1947هم، (6/1). النبهاله، تقي الدن، الثهصية الإبلامية، 991 م،ط3، (285/1). 


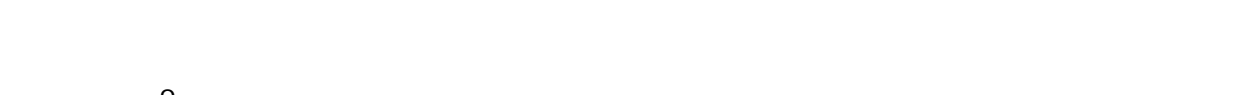

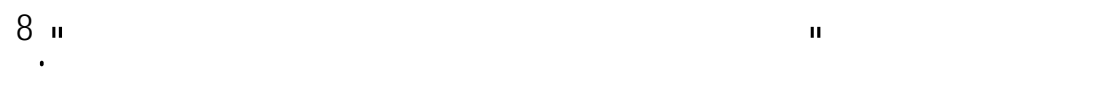

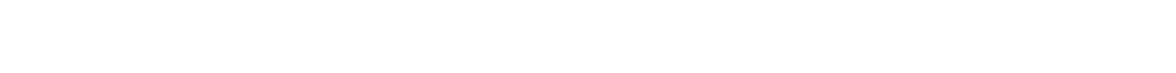

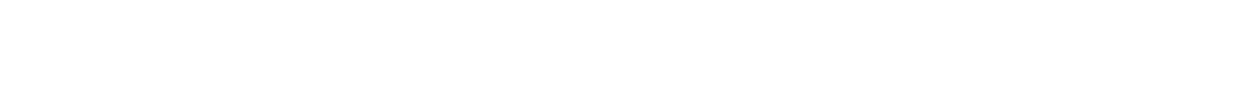

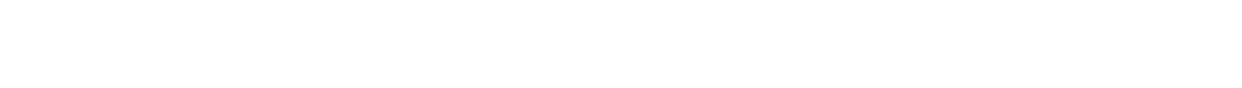

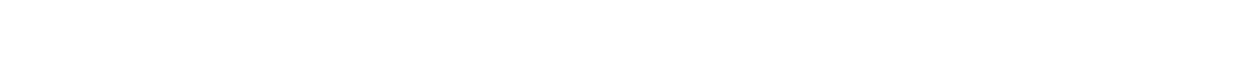

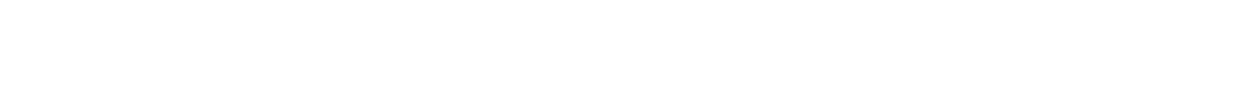

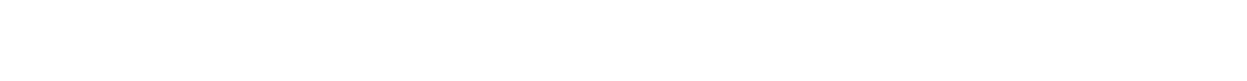

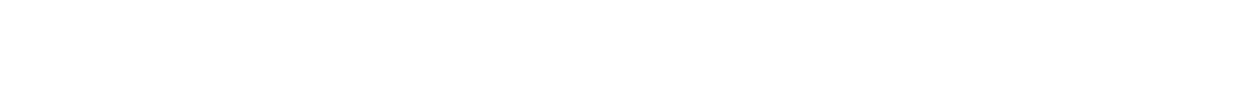

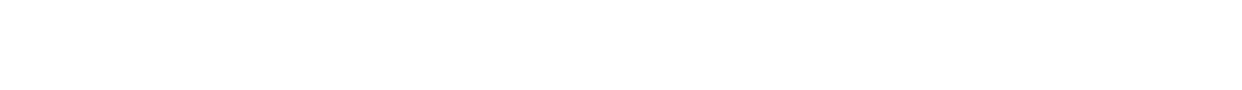
البض لُمضق، وسواء أفم البض وأحجم آخرون.

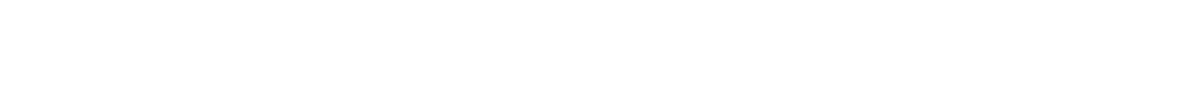

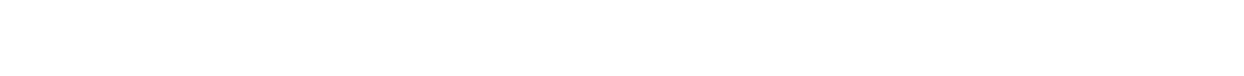

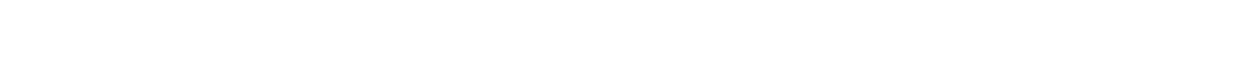

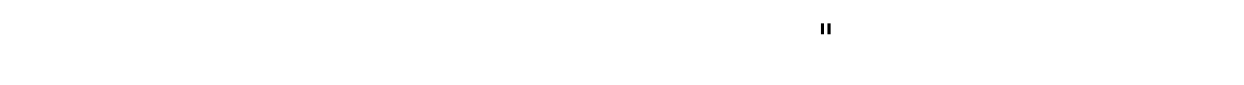

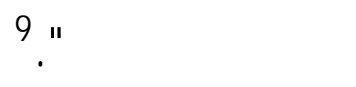

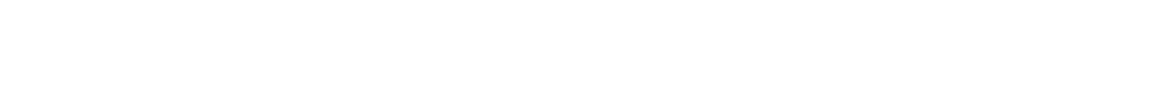

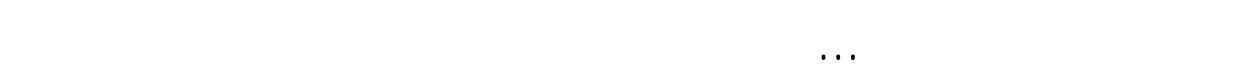

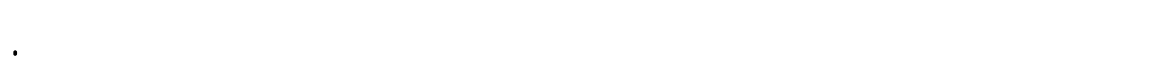

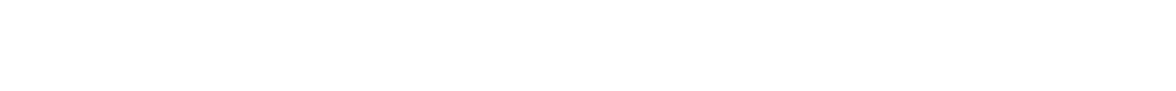

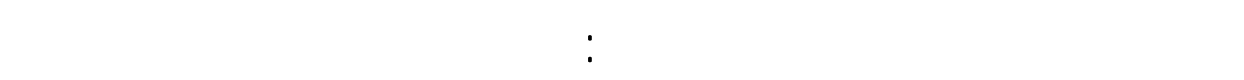

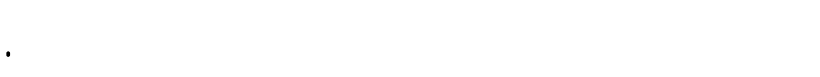

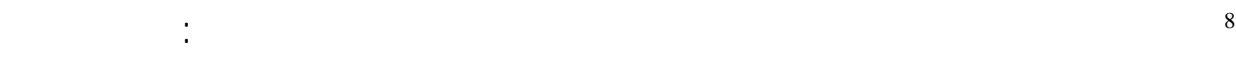
81 8981

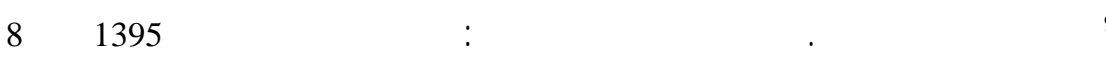




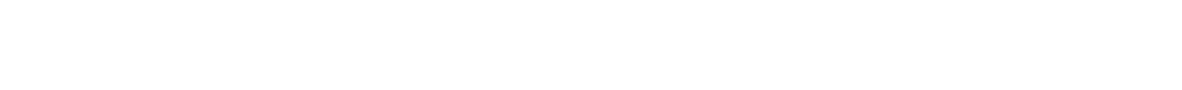

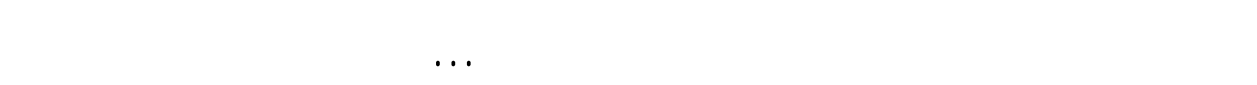

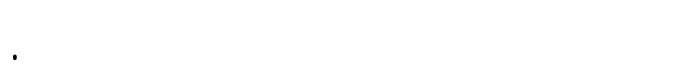

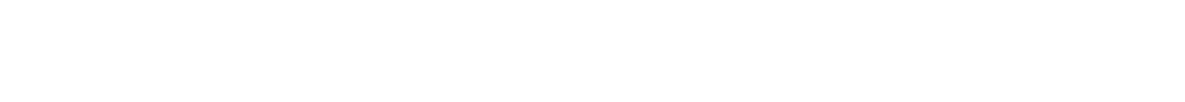

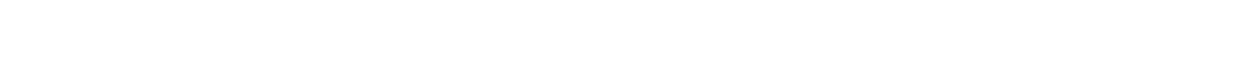
وجوهآلهارضة للقبطل.

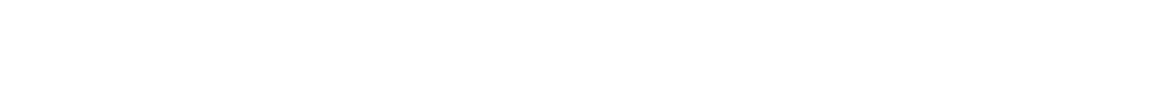

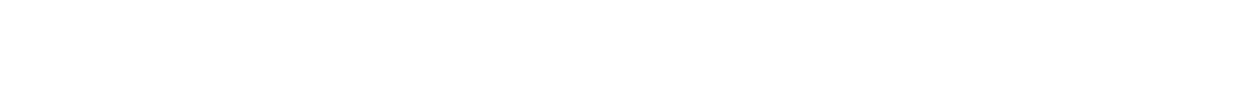

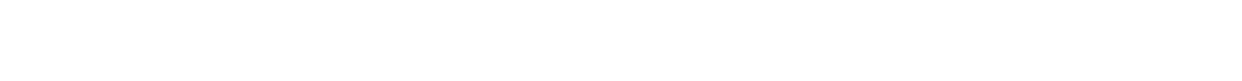
ودرلة تلك الأفول بهناية وتؤهه.

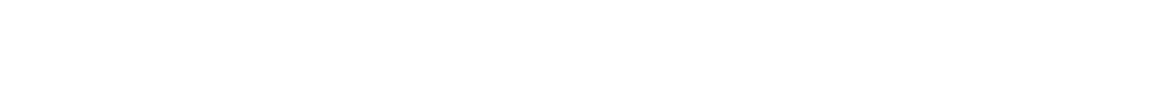

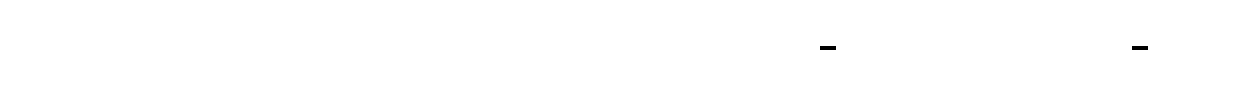

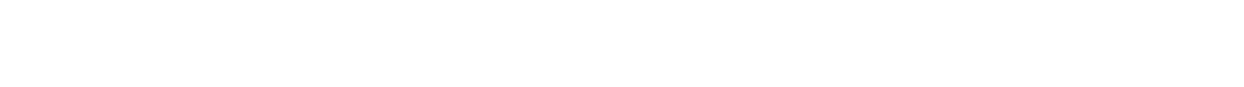

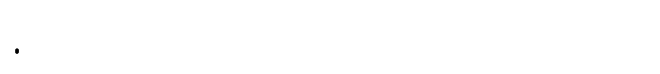

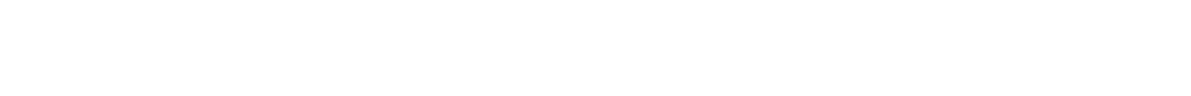

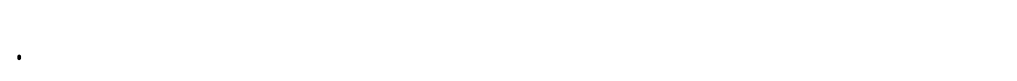

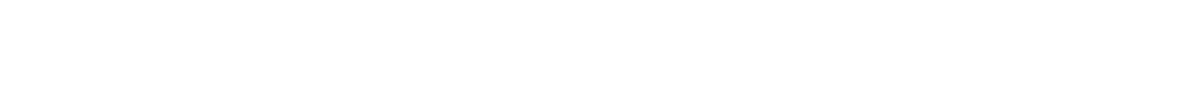

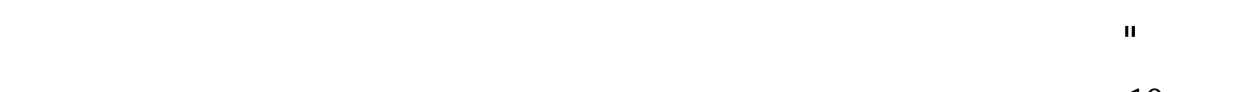

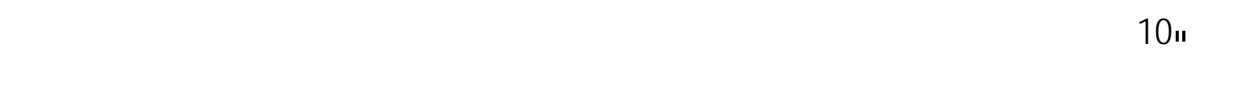

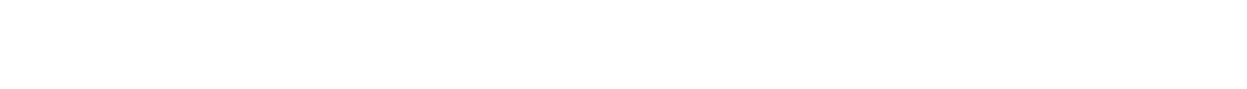

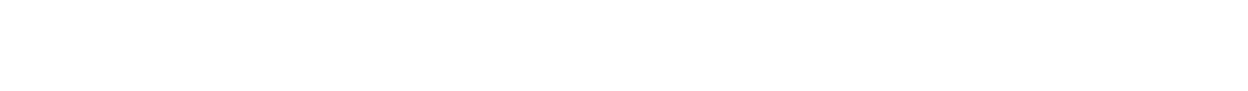

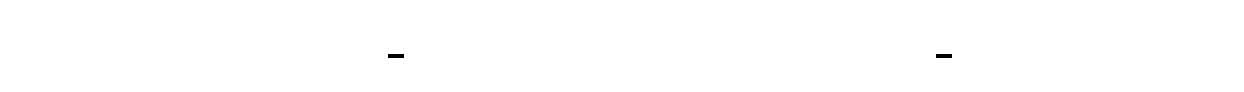




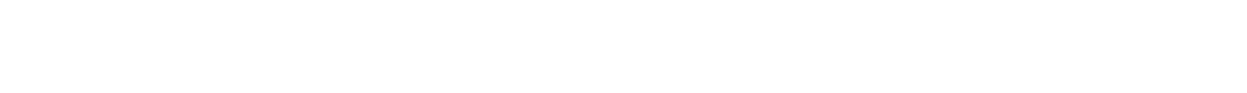

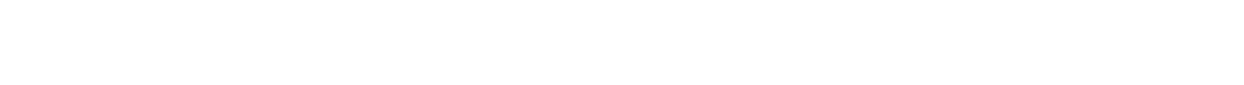

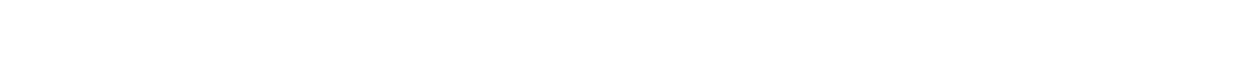

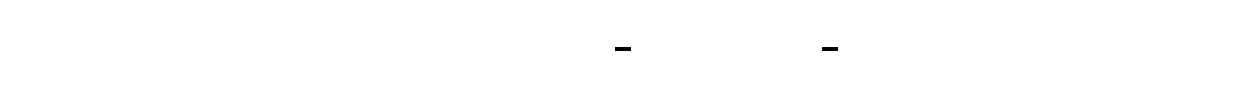
مسألة ققدآتنون.

\section{ثالياًا: لَٔسبلب القد}

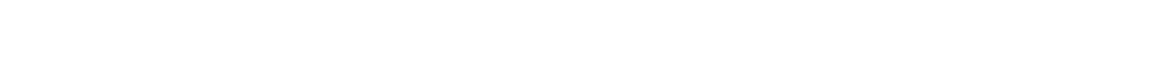

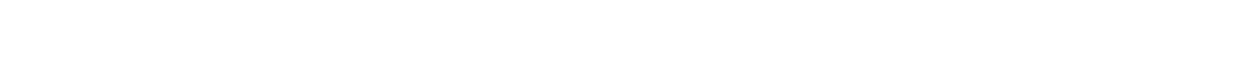

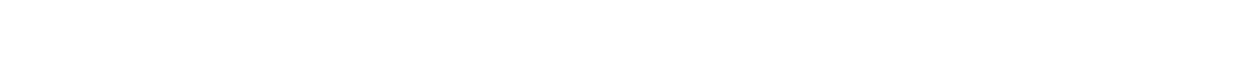

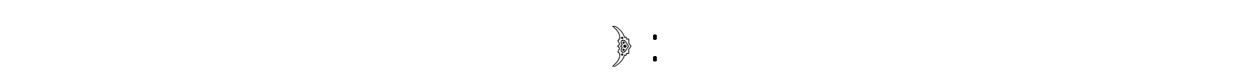

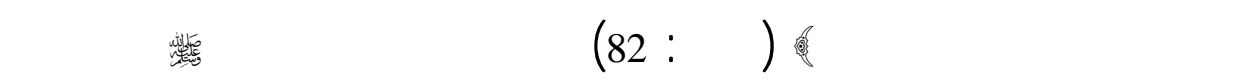

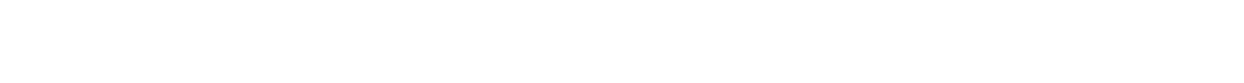

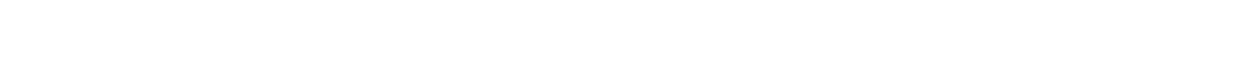

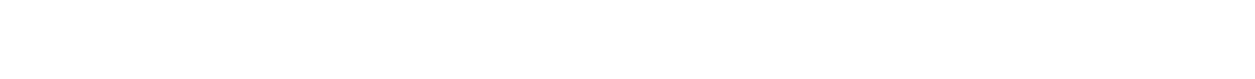
الفهم، والقراكة التئية، وهذا بيلن موجز لـذهة الأسبب.

\section{1}

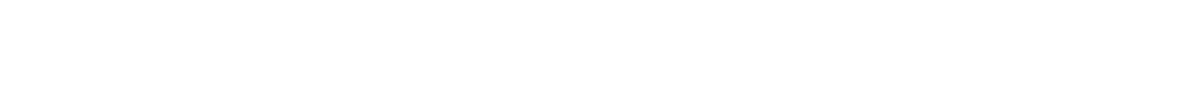

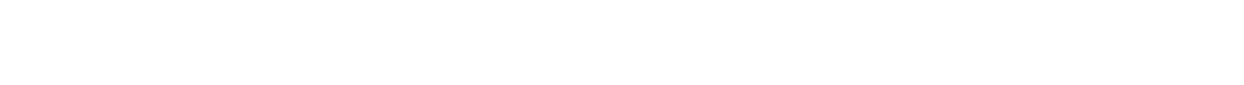

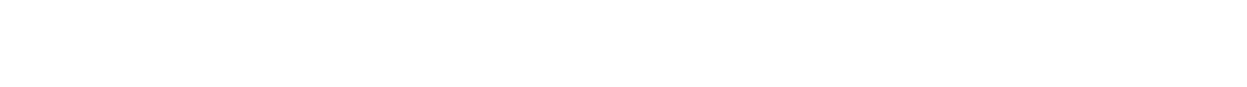

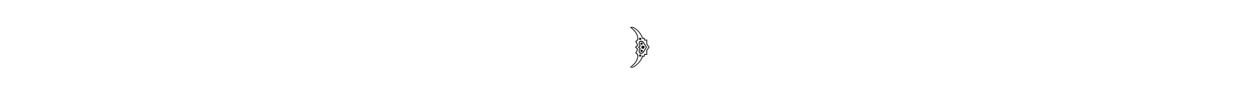

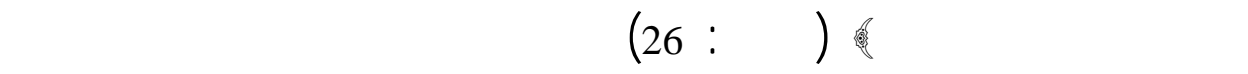
شاكلتهر الطعن والس كلماسنهت لهم الفرصة، لكن هيهت؛ فقد قلم علماء 


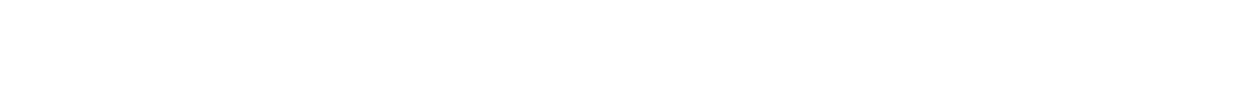

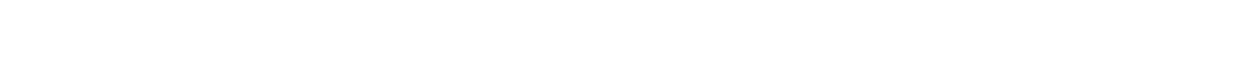

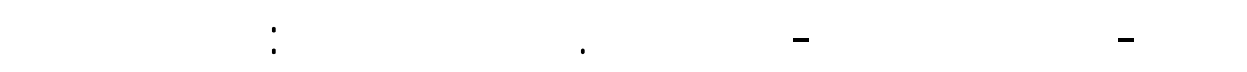

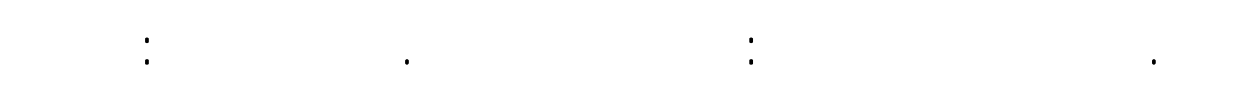

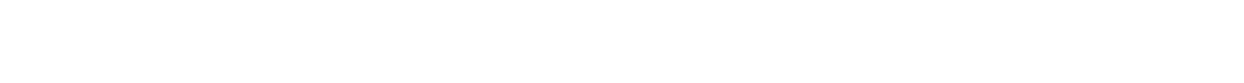

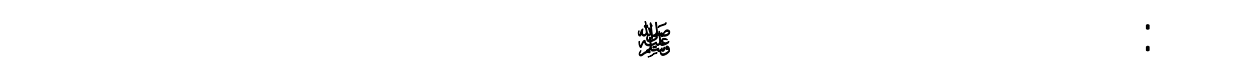

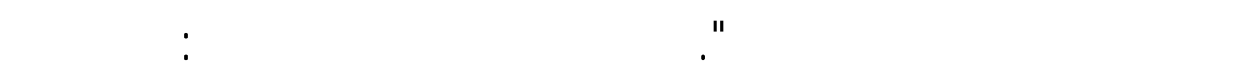

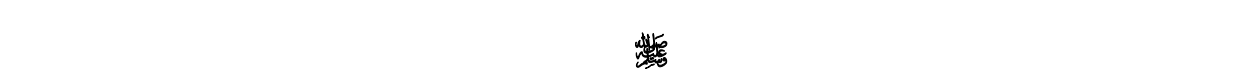

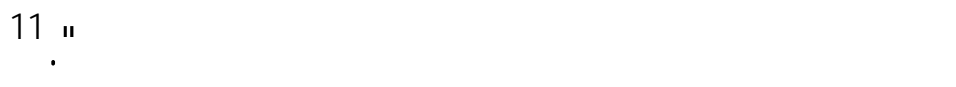

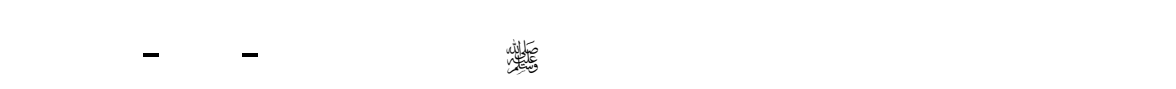

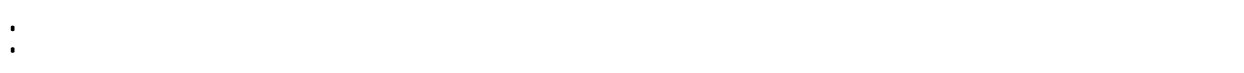

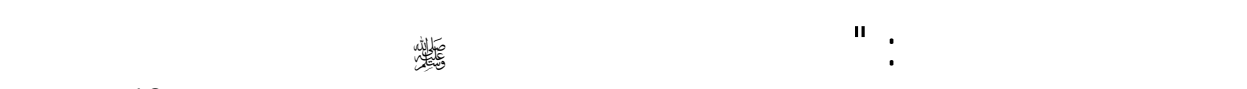

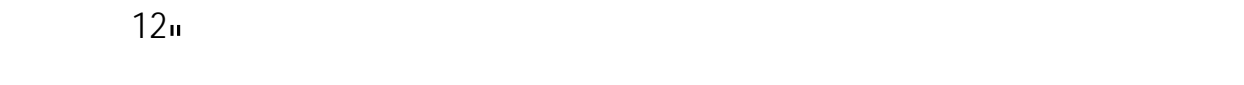

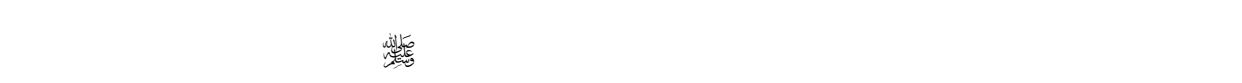
وهذا واضنح جلي معلوم لدى لألبة العلم.

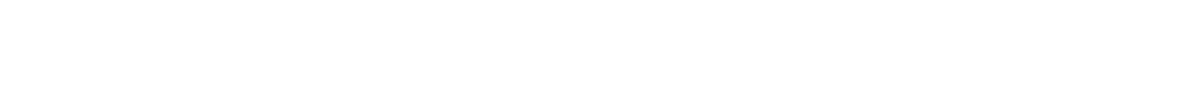

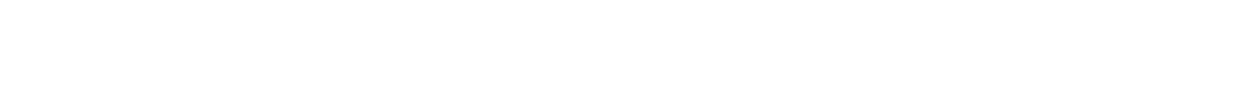

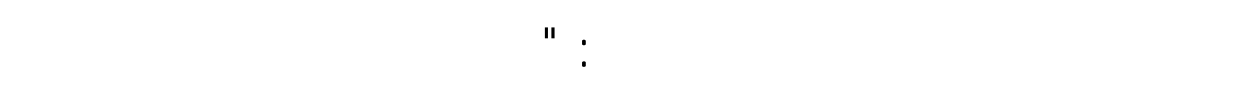

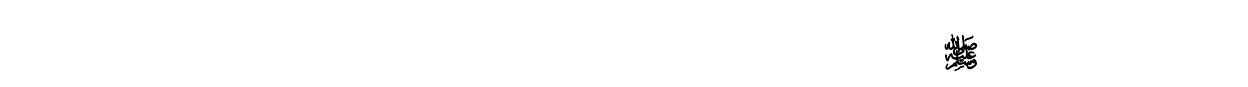

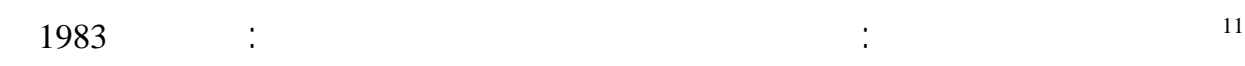

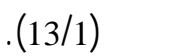

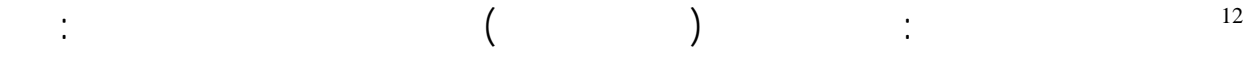

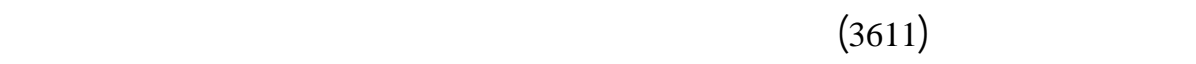

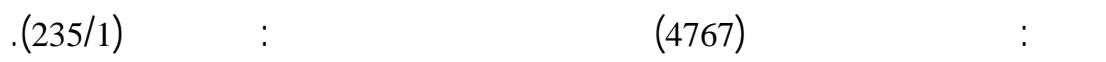




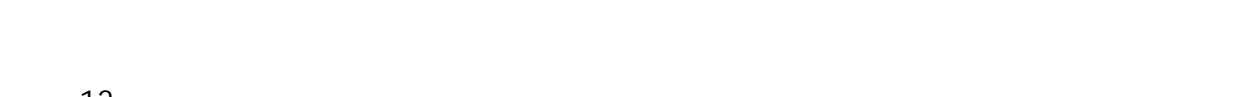

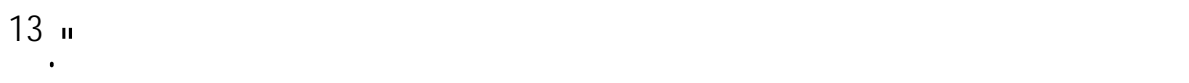

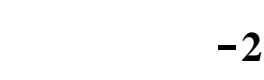

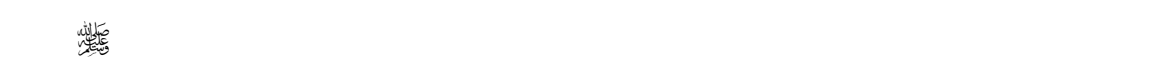

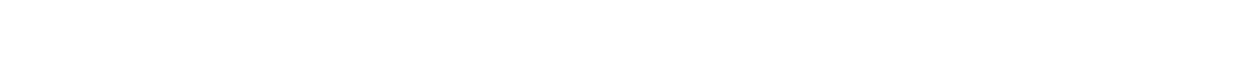

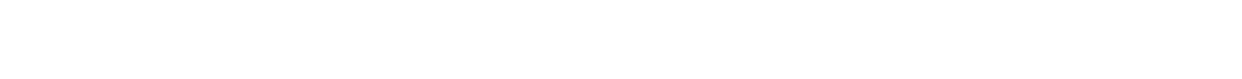

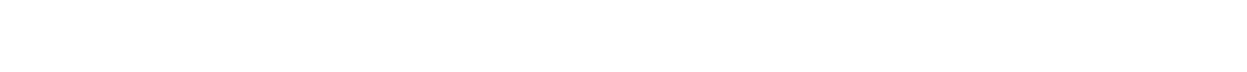

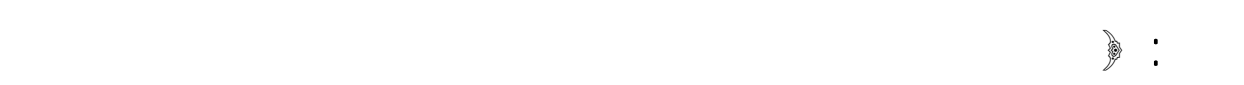

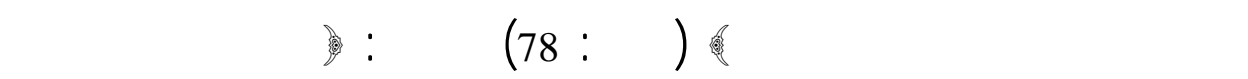

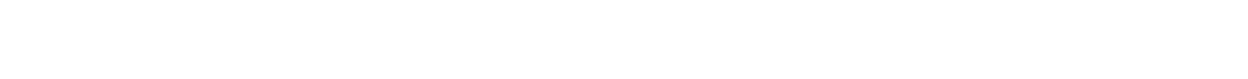

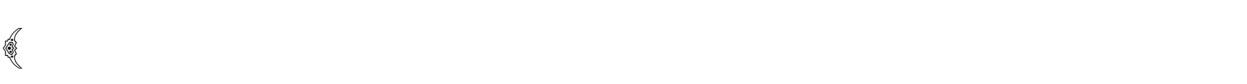
(الأحقف: 26).

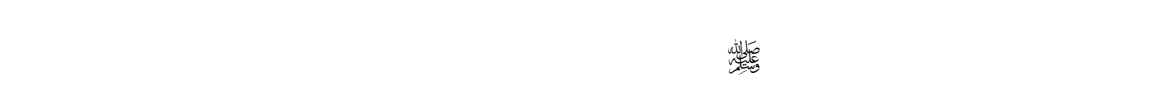

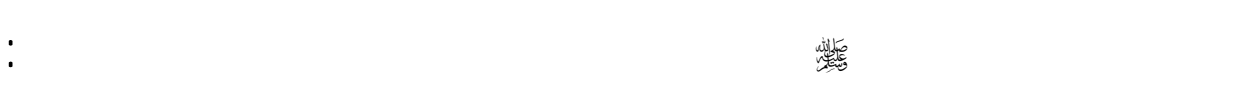

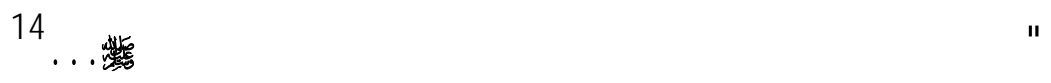

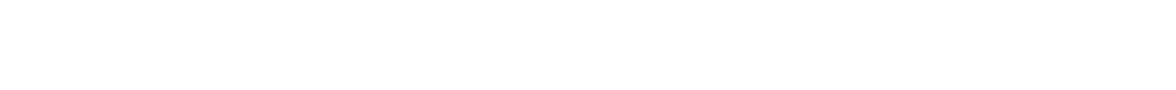

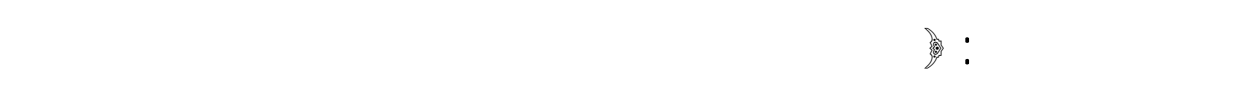

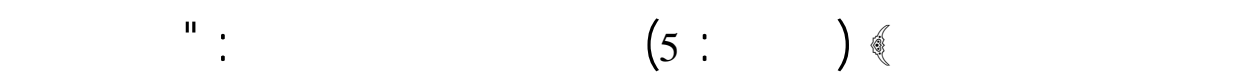

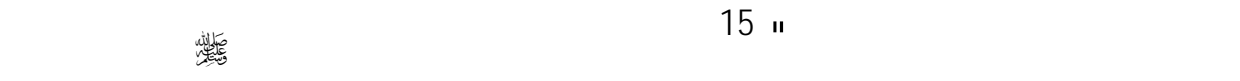

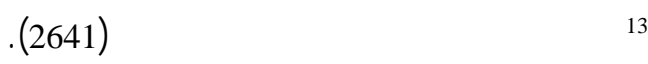

(14 ${ }^{14}$

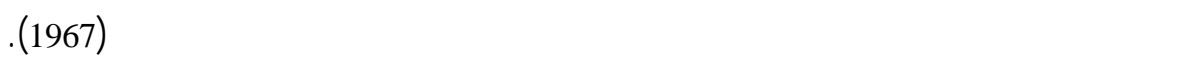

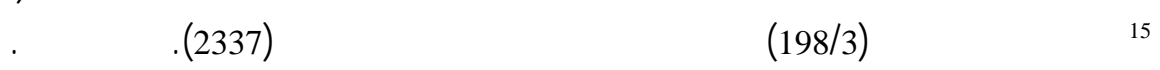


فايزعبد الفتاح أبوعمّا

158 لبلامية إلهرفة، السة النلنهة، العدد 39،شتاك 1426هـ/2005م.

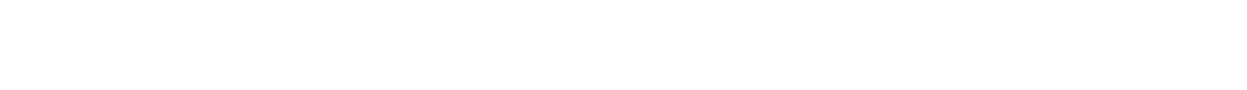
هذه الأنطاء.

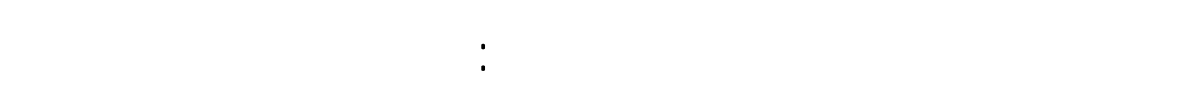

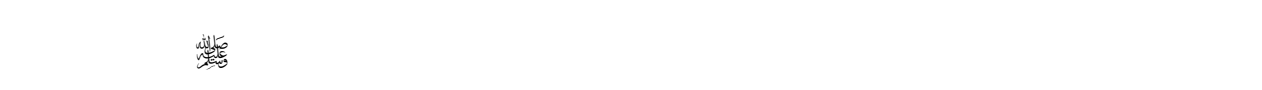

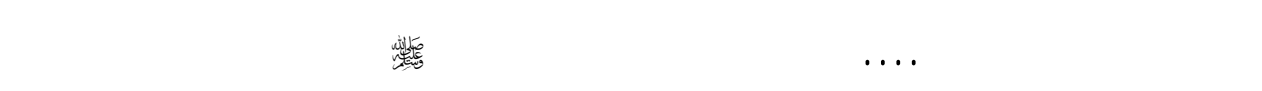

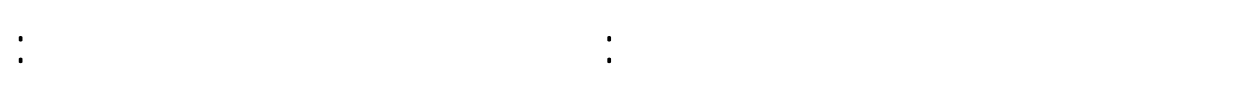

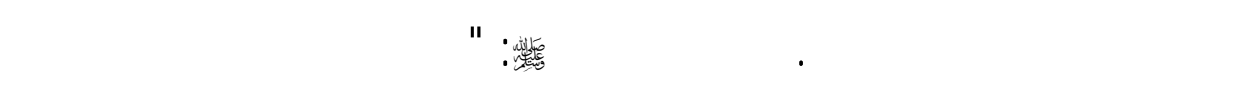

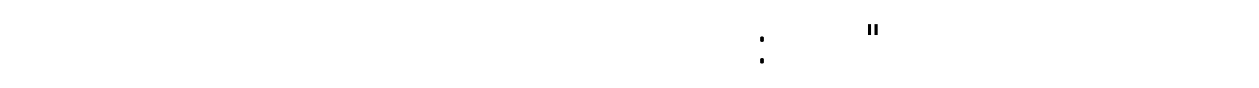

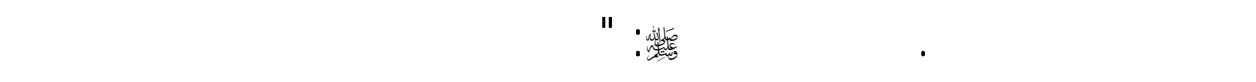

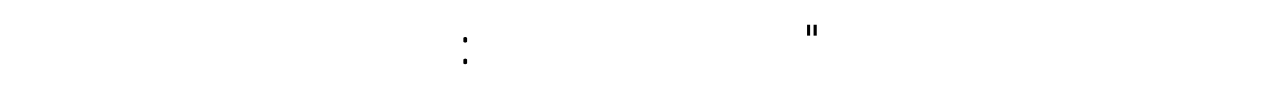

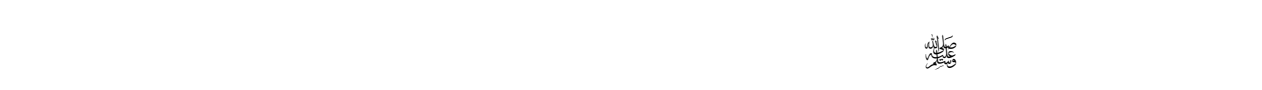

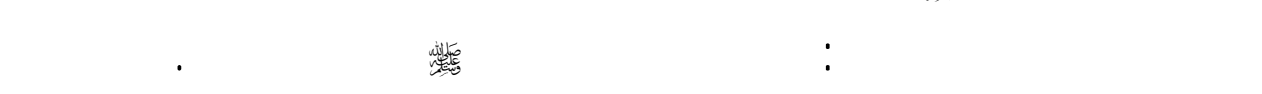

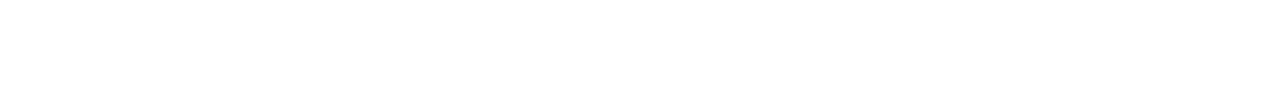

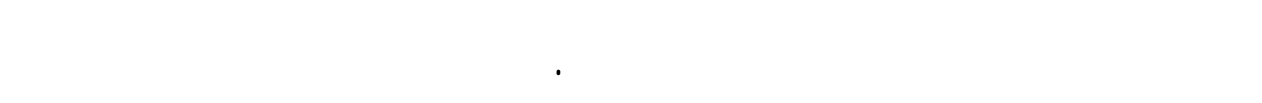

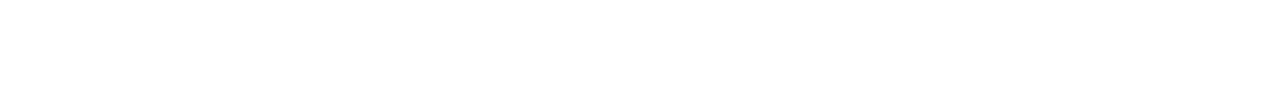

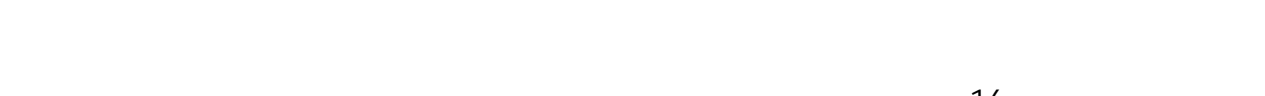
حدثيه ألط مرة. 16

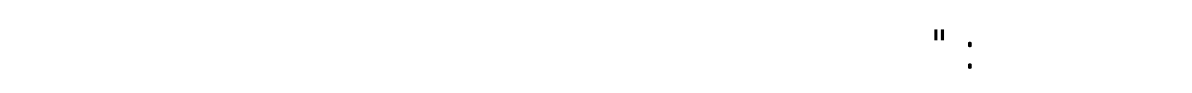

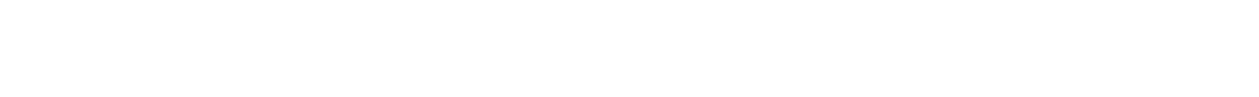

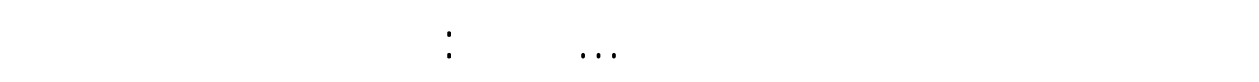

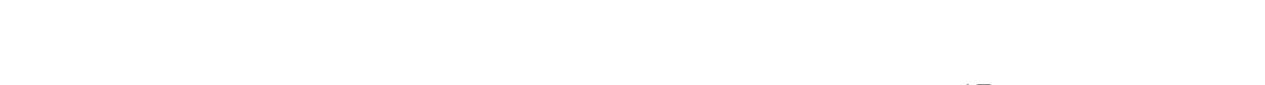

العلم وظّ ذلك". 17

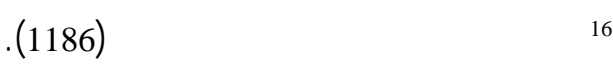

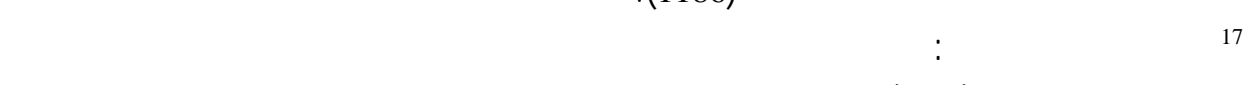
بـوت: دالهيهة، (62/3). 


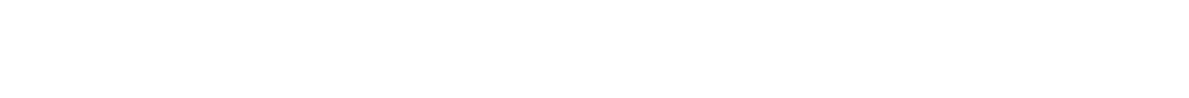

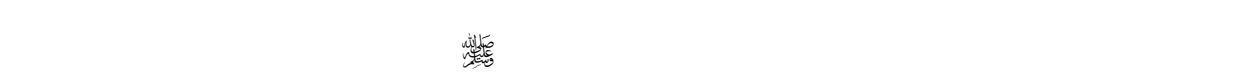

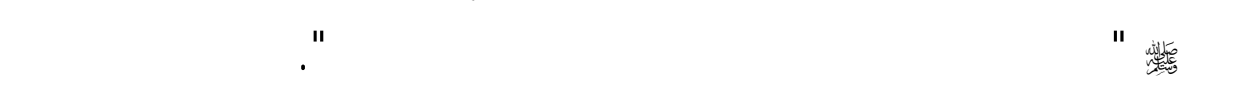
هـلب جالسافقد كذب فقد وإ]صليت معه أكزرمن ألفي صلة" 18

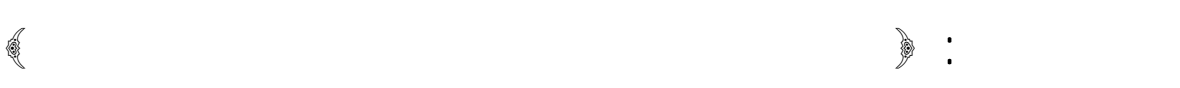

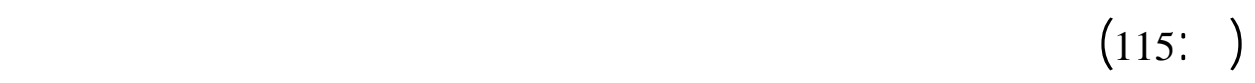

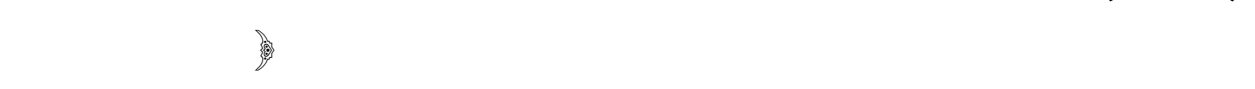

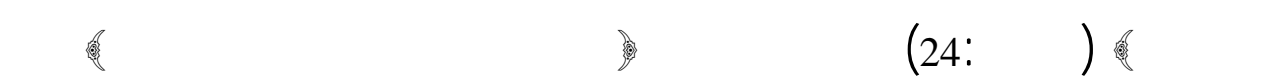

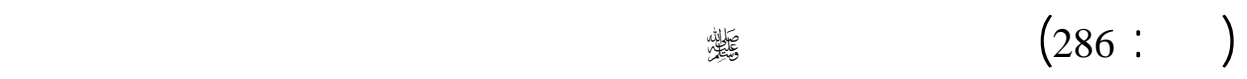

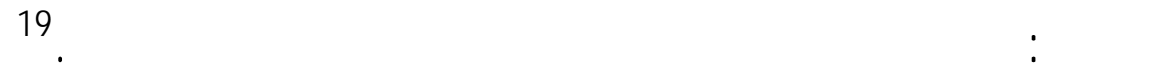

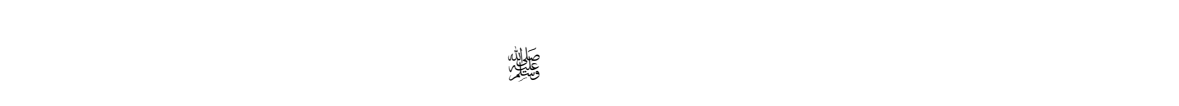

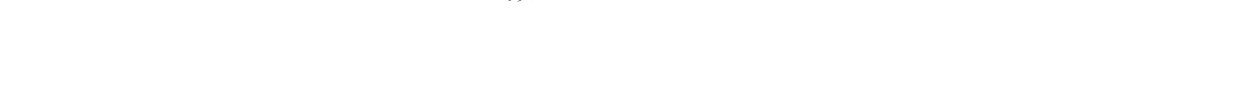

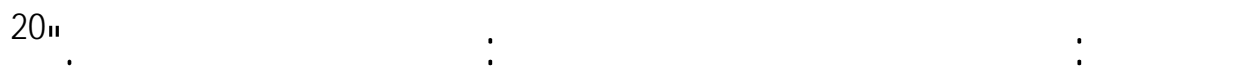

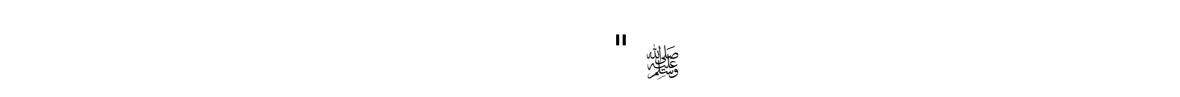

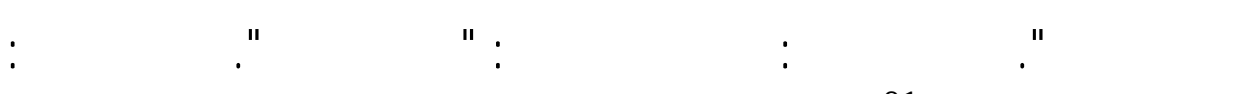

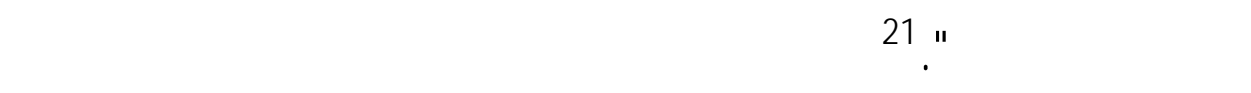

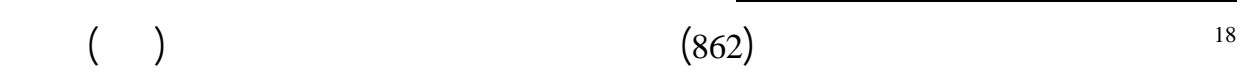

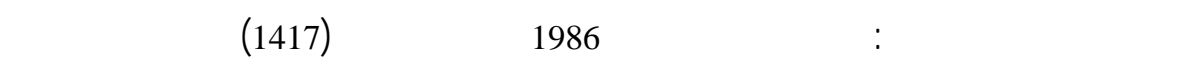

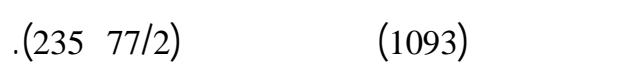

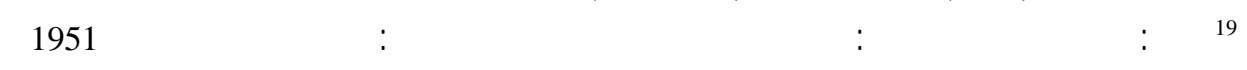

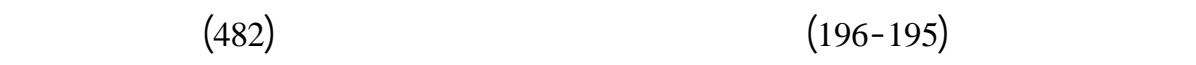

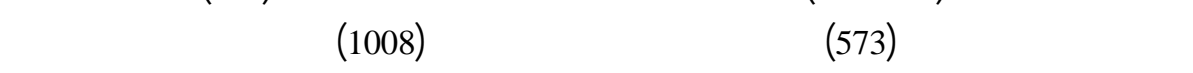

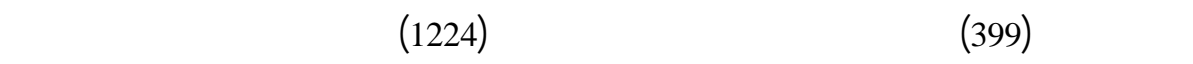

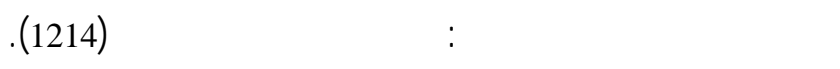

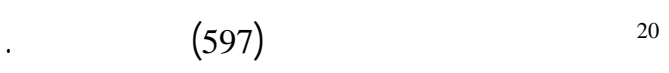

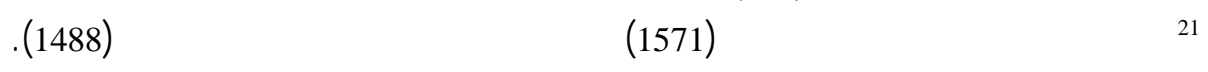




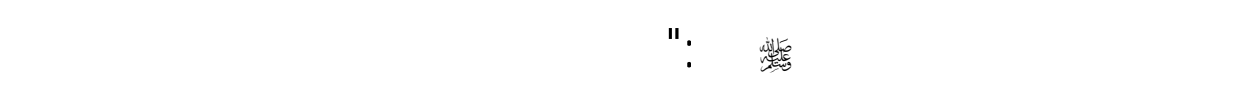
22. C

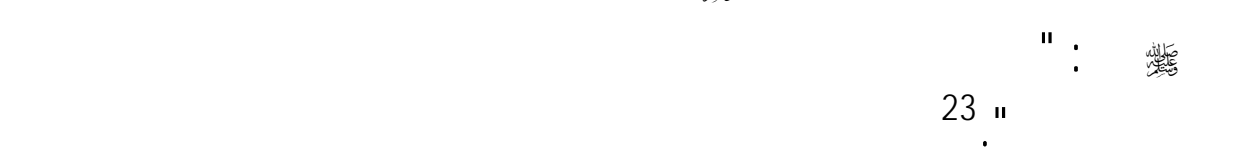

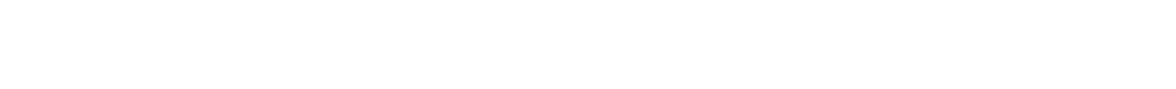

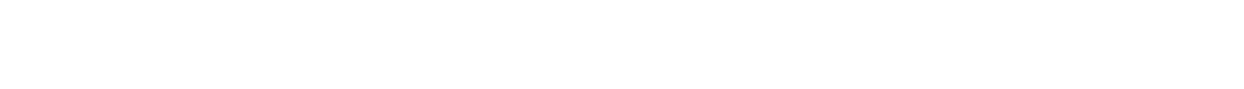

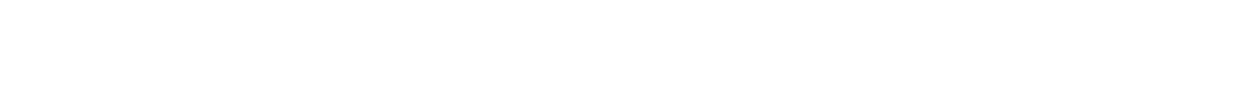

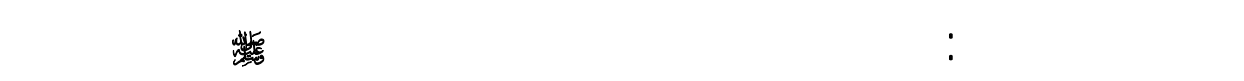

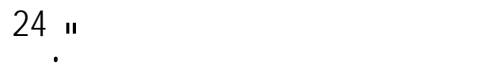

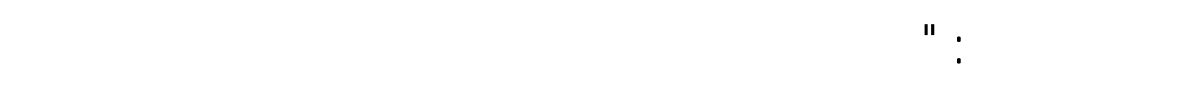

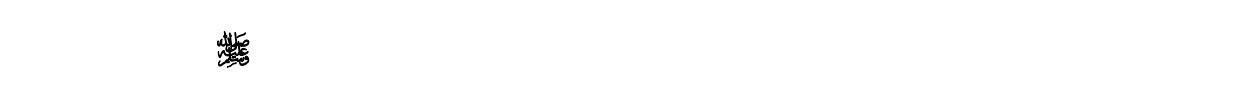

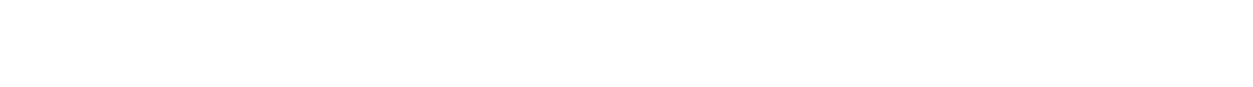
تقيتها من كلةقشولئب الأغطاك،سواء كلن ذلك بالنسيل لم بالنعمد". 25

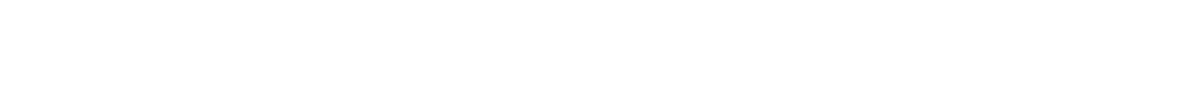

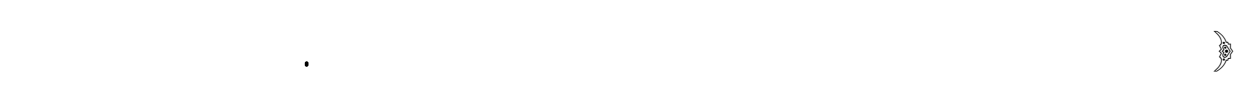

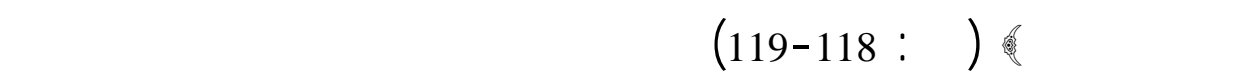

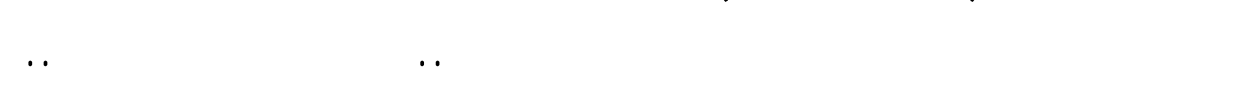

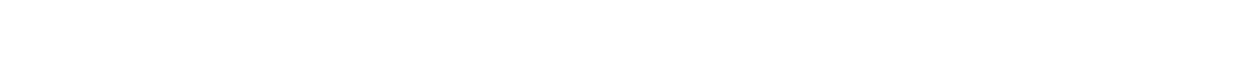

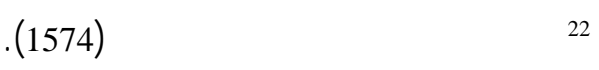

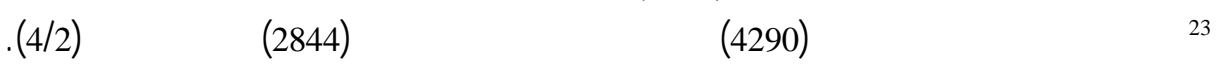

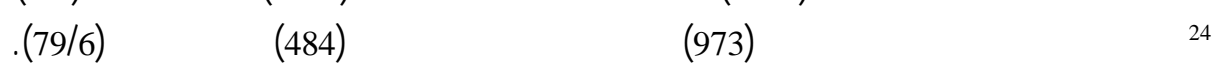
25 الأغظمي،ققدة كنلب التمييز، مرجعسلقص كلبر (7). 


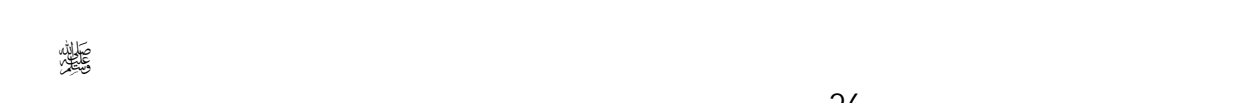

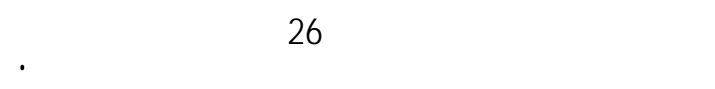

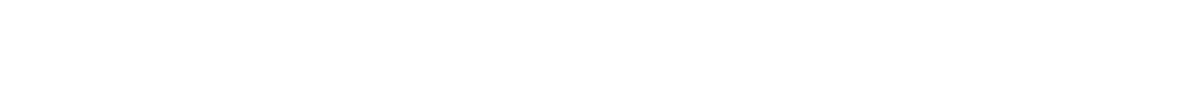

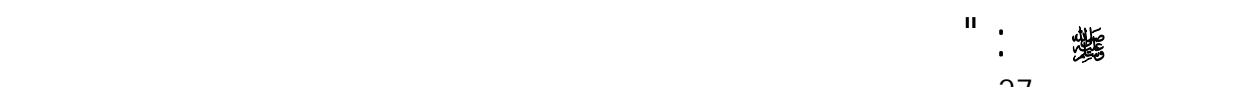

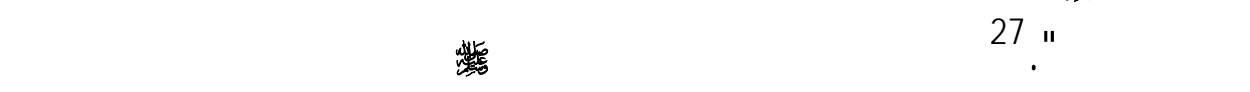

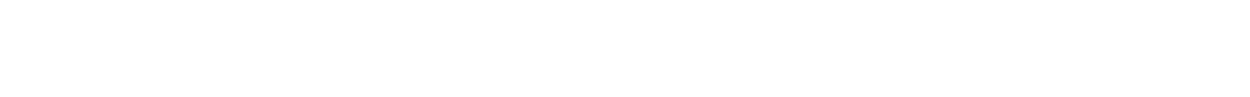

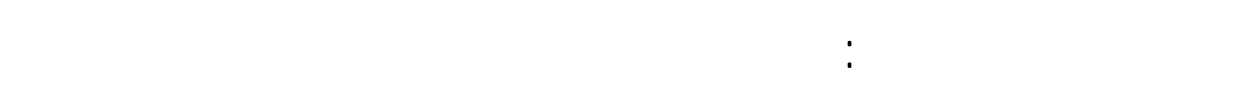
هن الصحية".

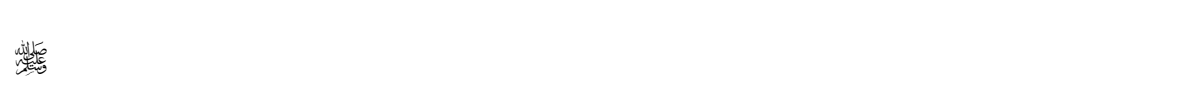

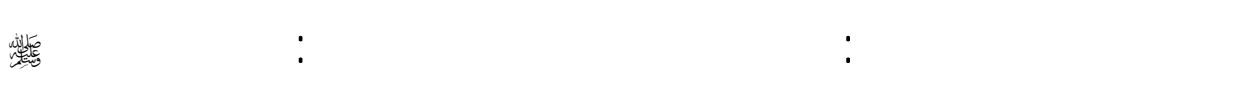

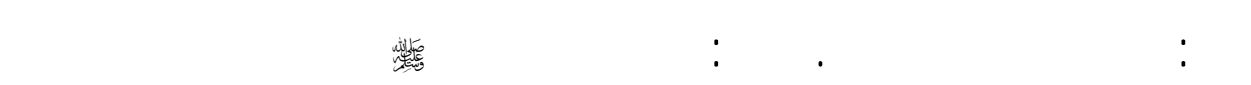

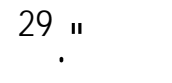

\section{4. الفرأة الزئة}

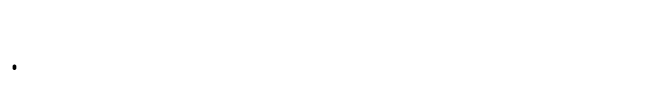

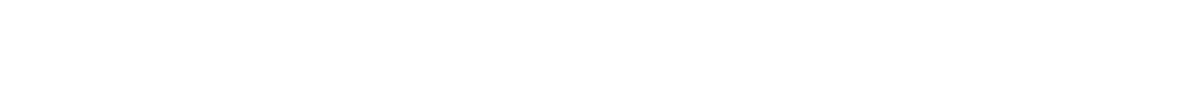

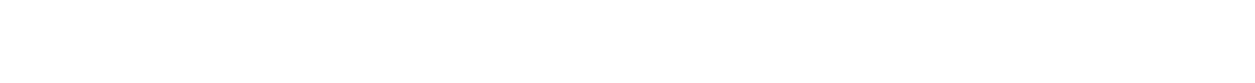

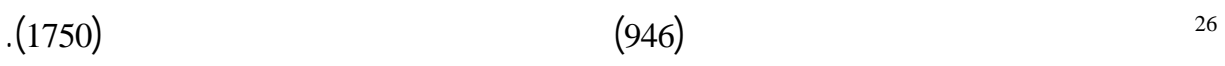

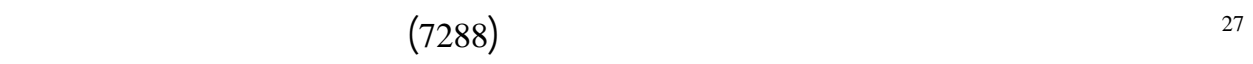

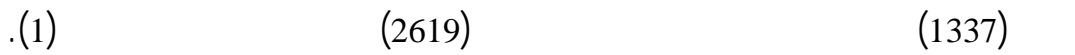

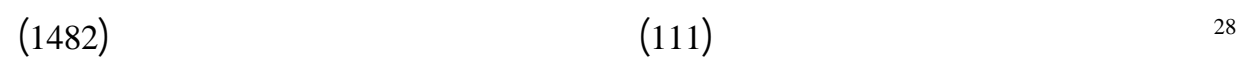
والنسئي، السنن، كنب القنالة (4744).

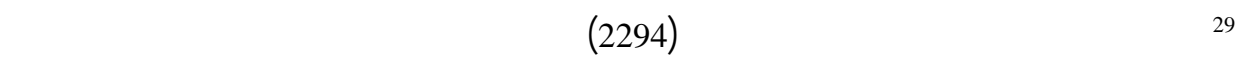

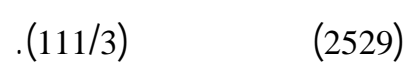




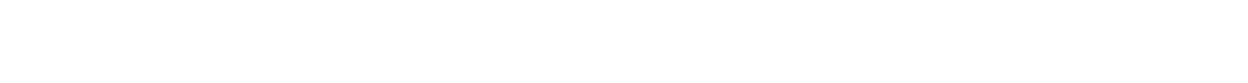

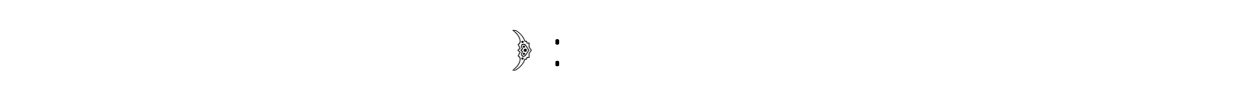
: الأنعل

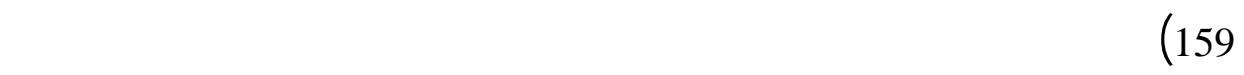

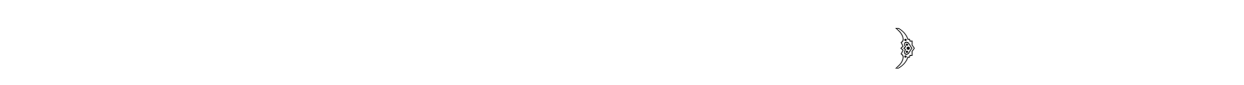

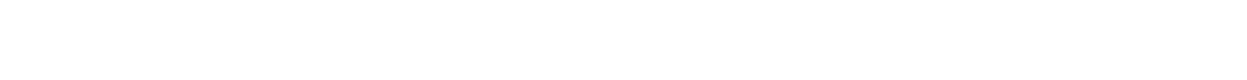

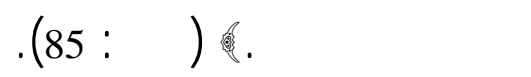

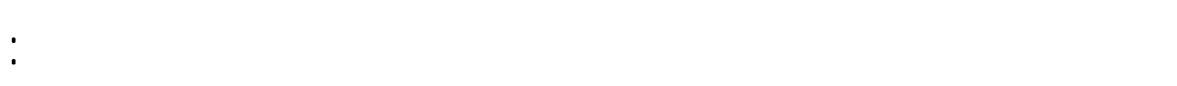

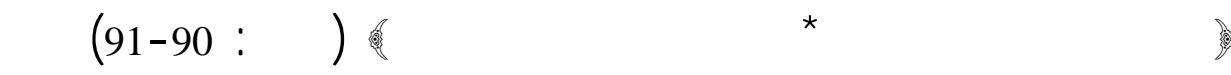

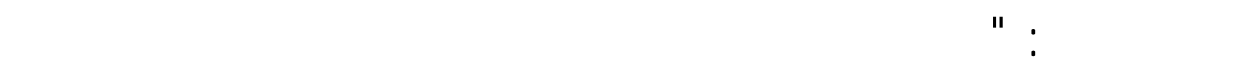

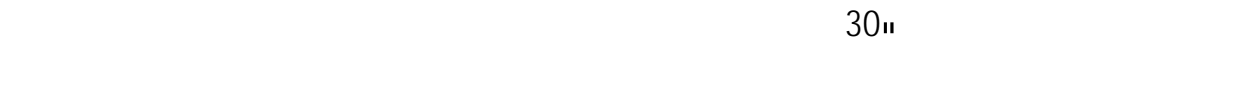

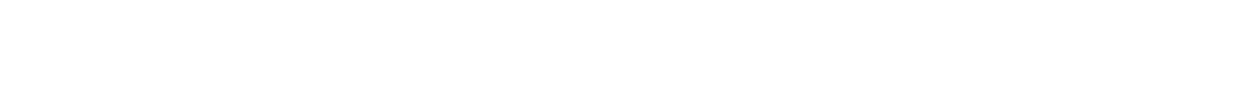

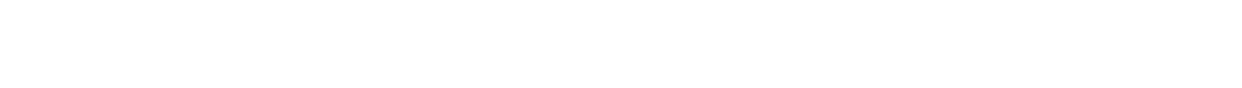

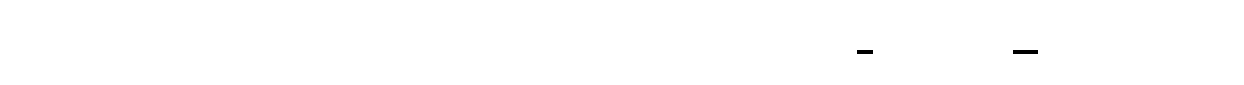

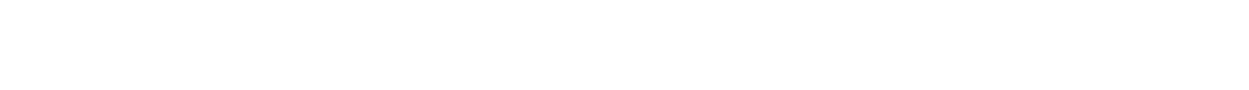

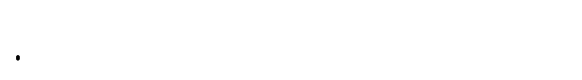

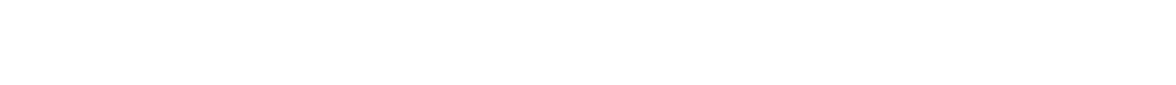

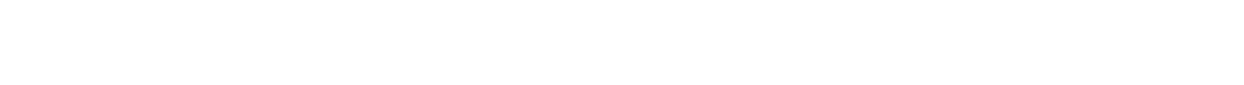

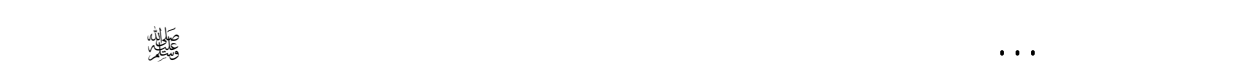

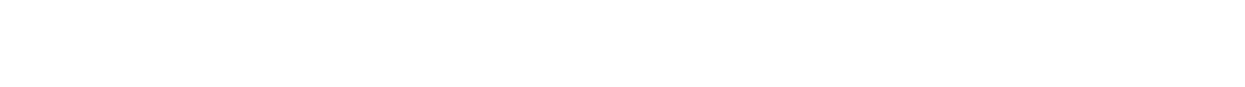

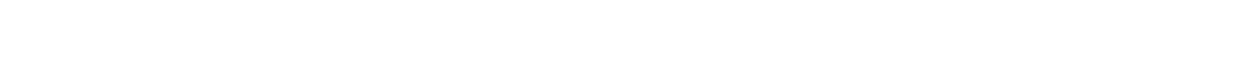

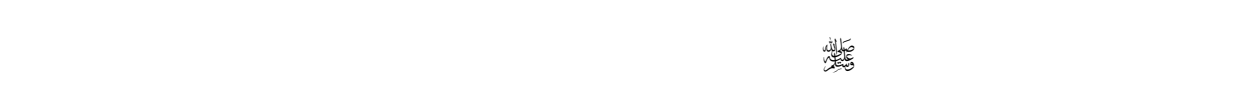

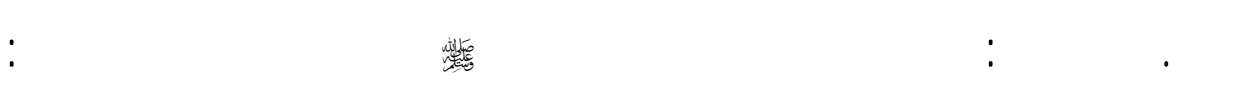




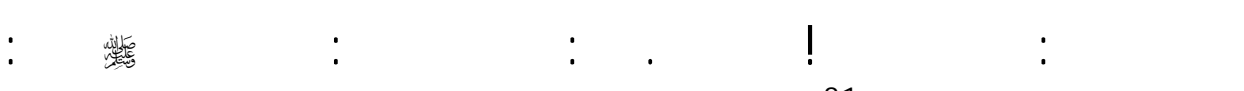
31 ".

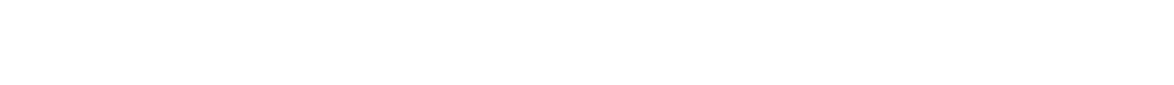

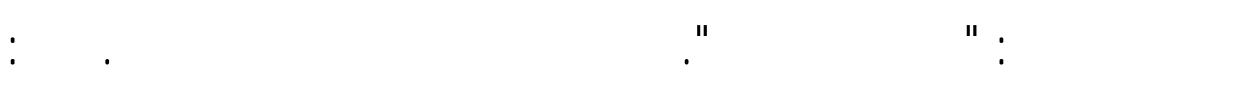

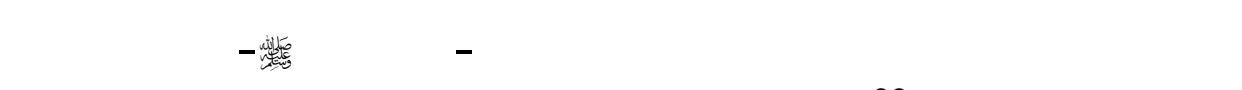

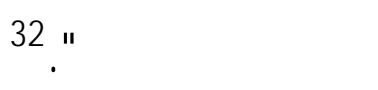

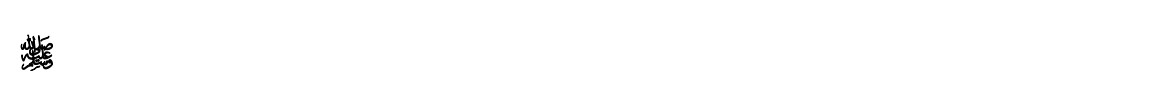

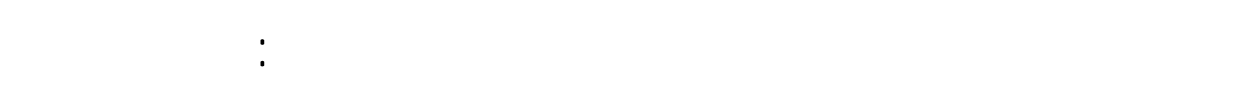

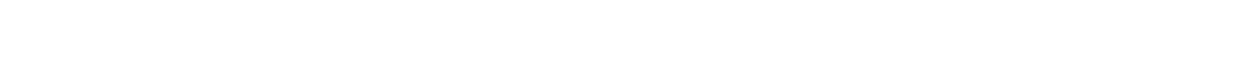

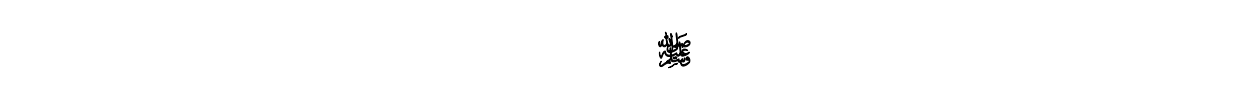

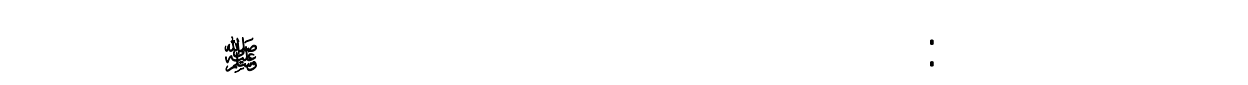

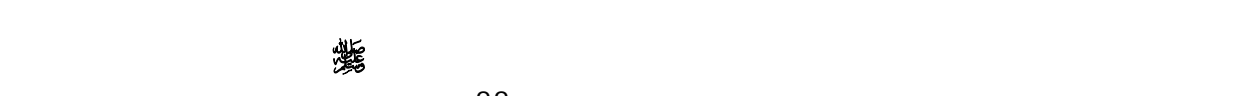

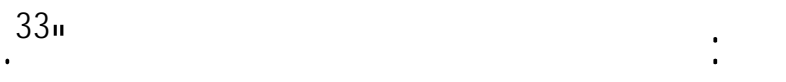

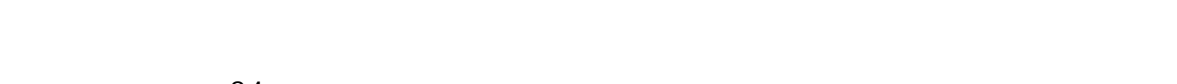

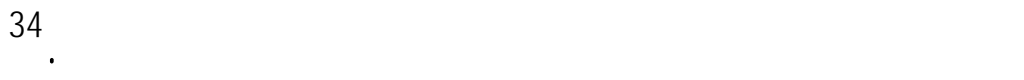

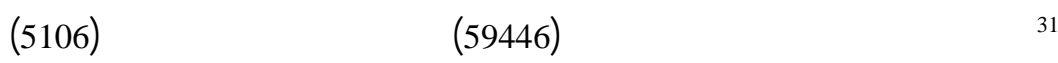

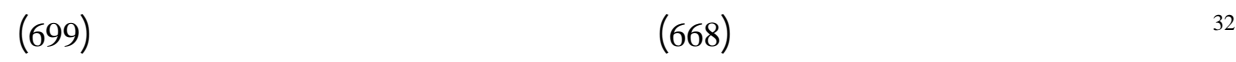

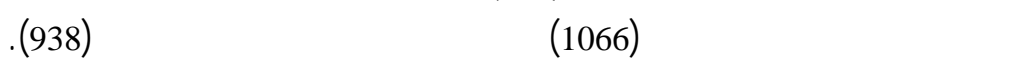

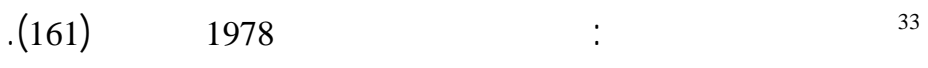

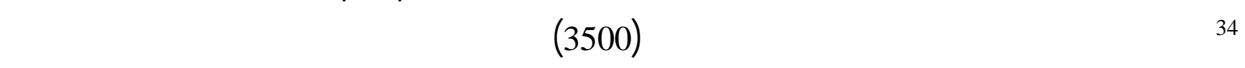

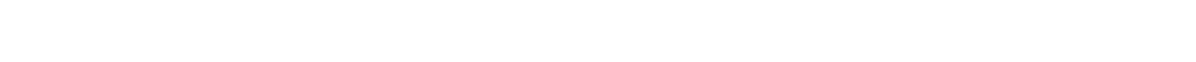

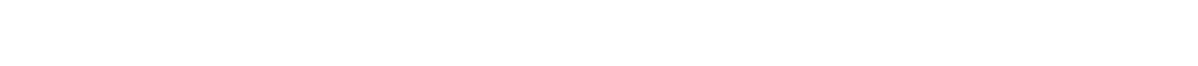

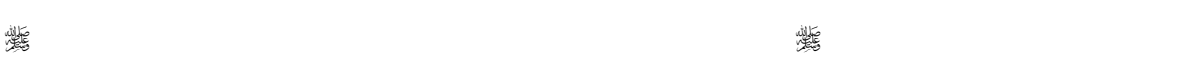

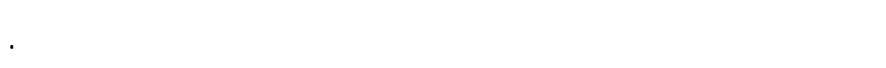




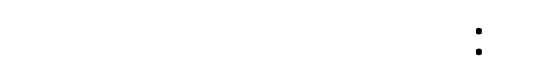

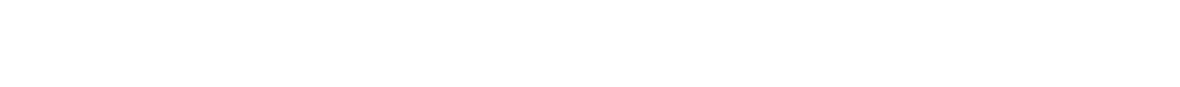

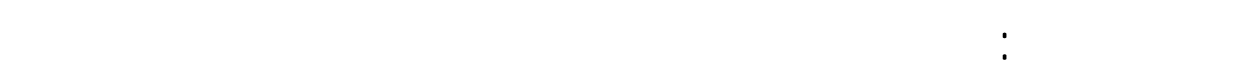

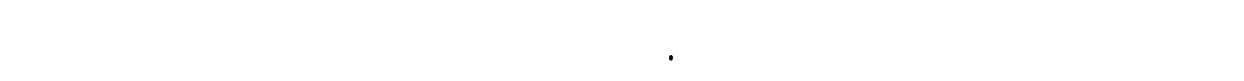

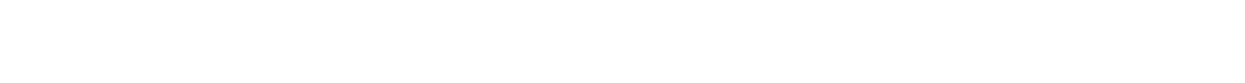

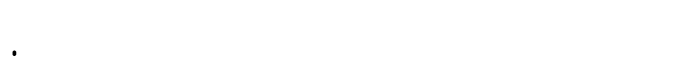

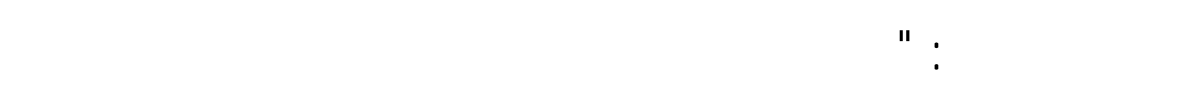

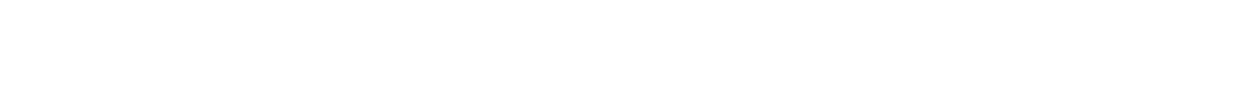

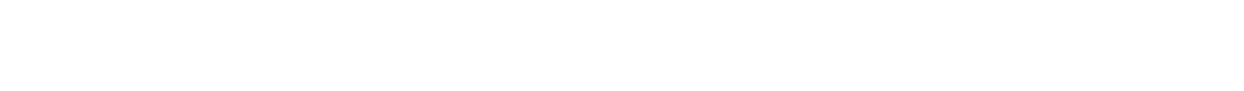

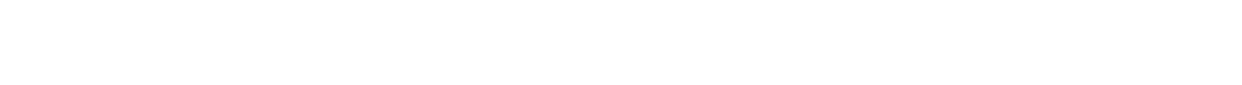

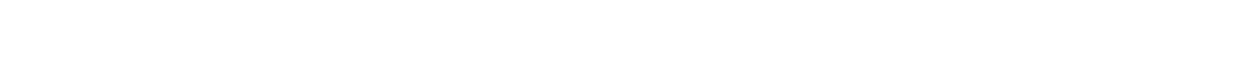
موضوع أومقلوب أومهلس، وهذا لُٔشكلى الأمور". 35

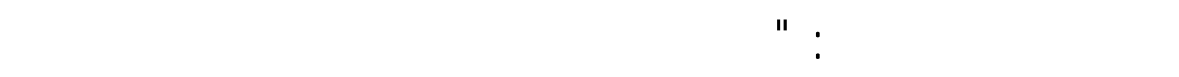

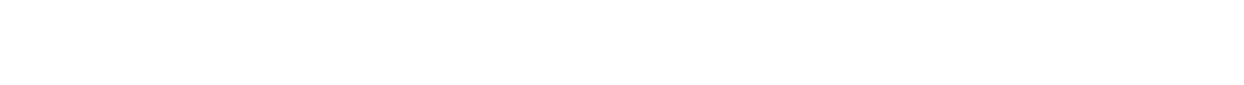
مقطوع به". 36

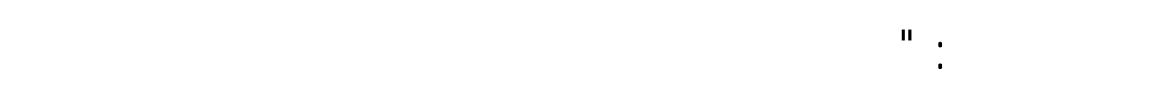

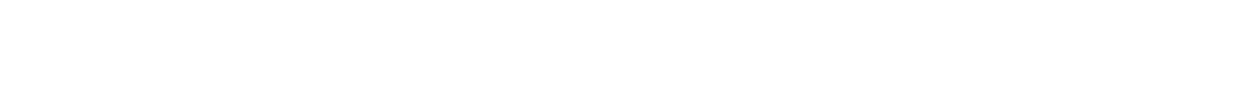

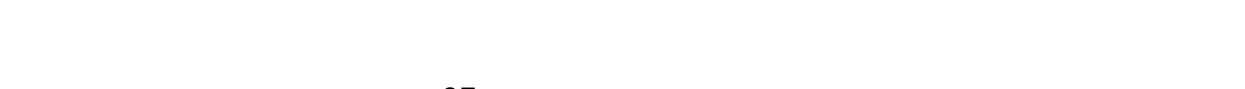

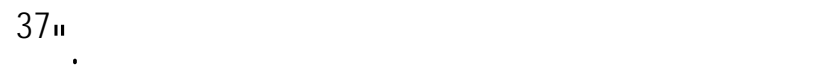

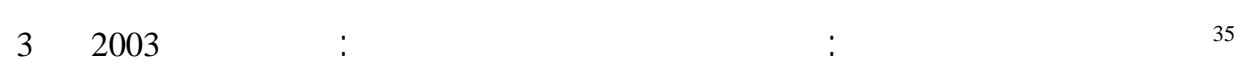
(122/2)

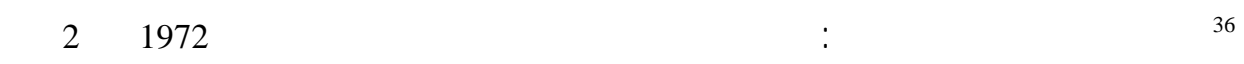
606، واظظر: السيولي، تمرب الرإئ مرجعسلق (276/2).

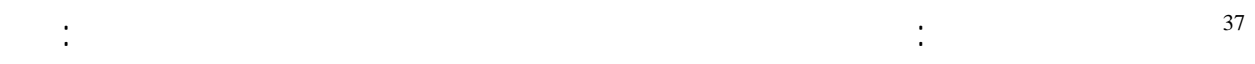

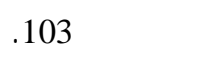




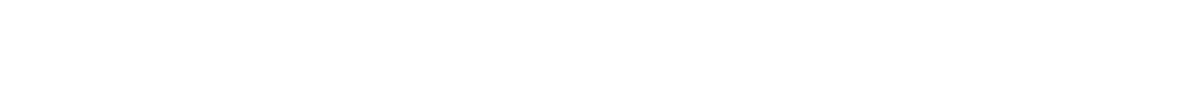

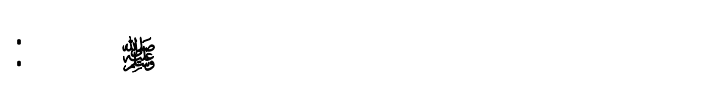

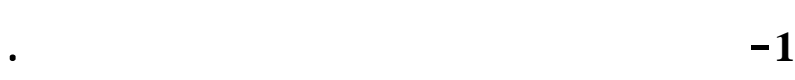

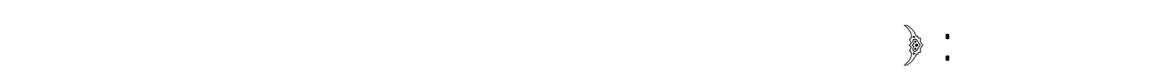

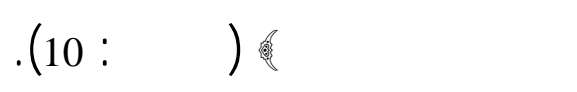

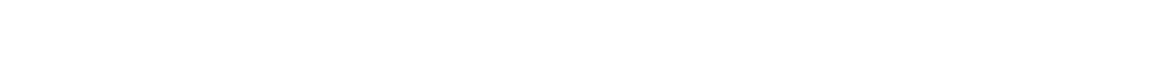

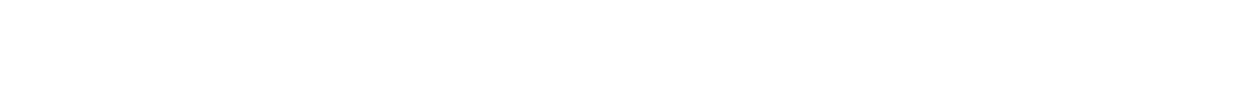

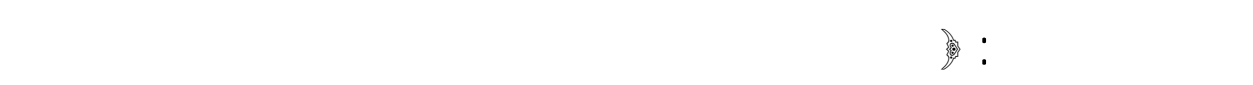

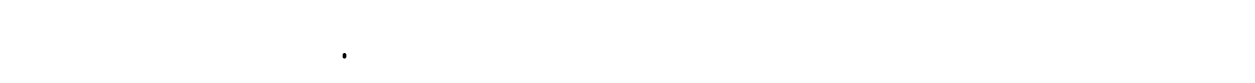

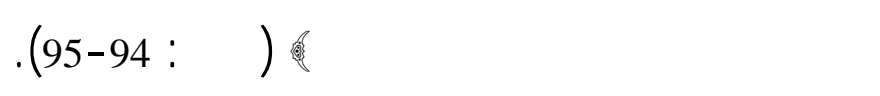

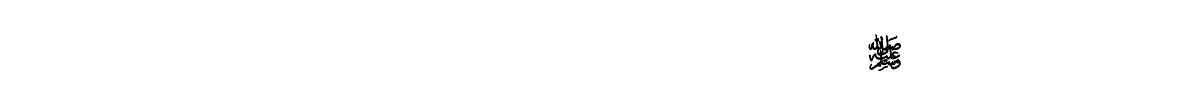

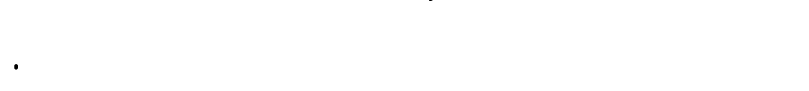

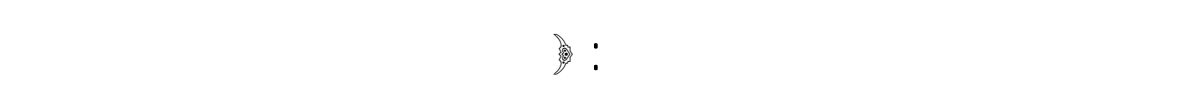

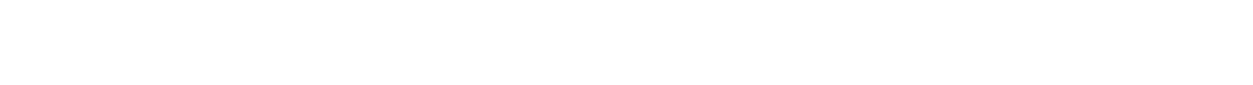

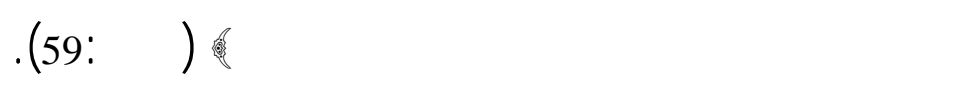

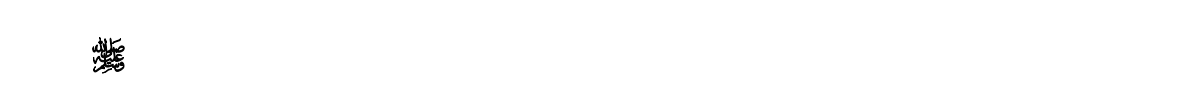

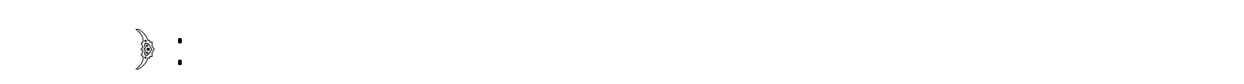

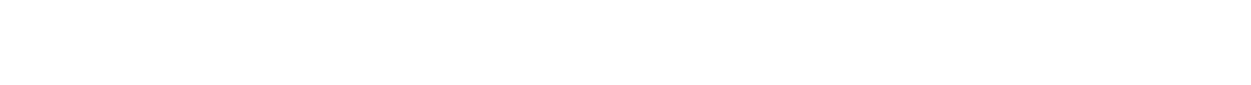

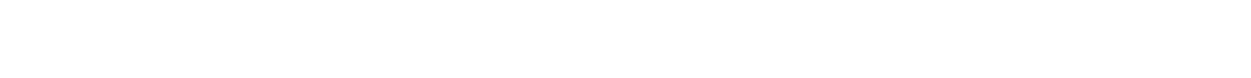

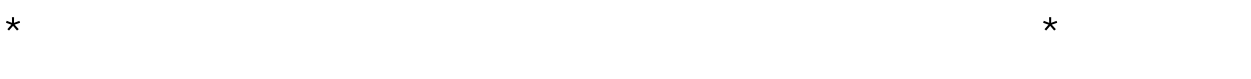

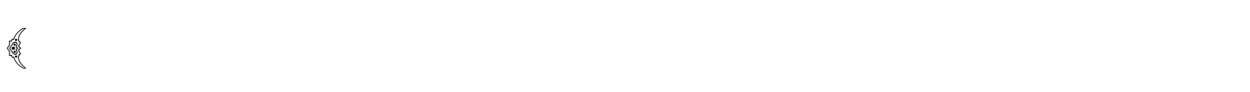
(4سأ: 43 -45). 
فايزعبد الفتاح أبوعمَّا

166 لبلامية إلهرفة، السة النالنعة، العدد 39،شتاك 1426هـ/2005م

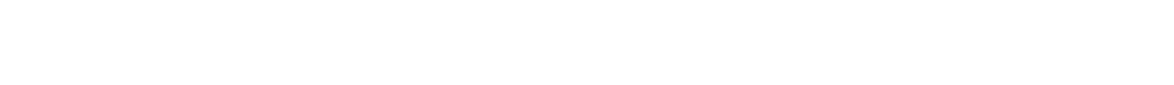

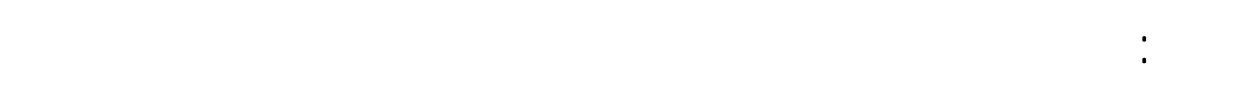

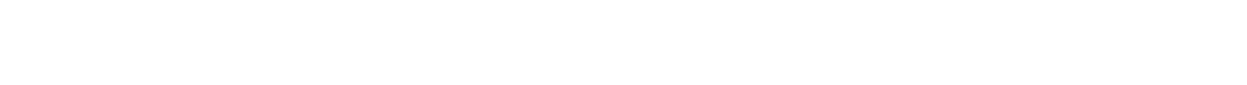

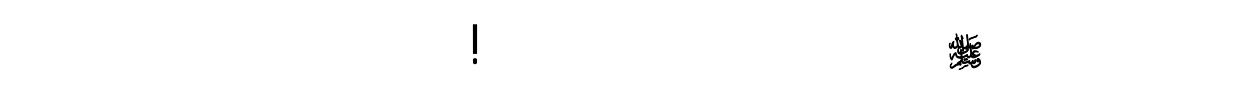

أفنسهم.

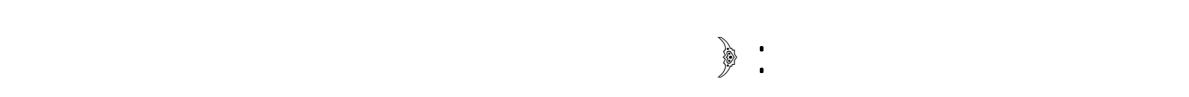

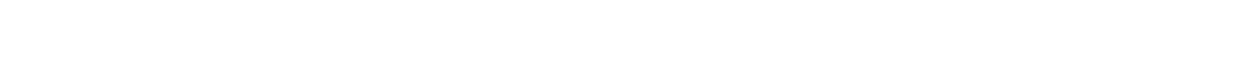
然

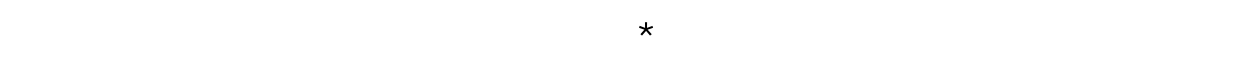

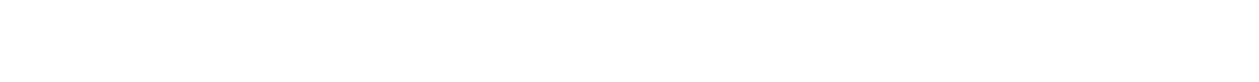

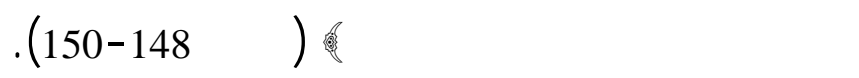

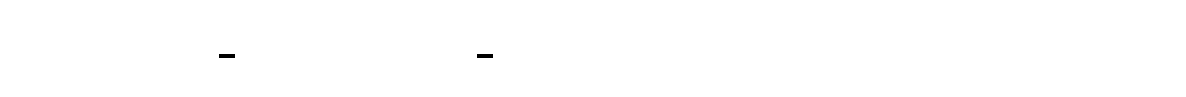

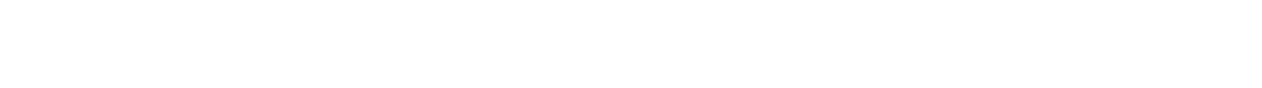

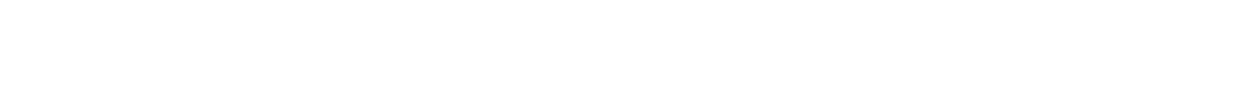

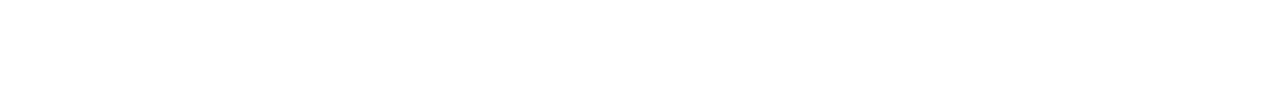

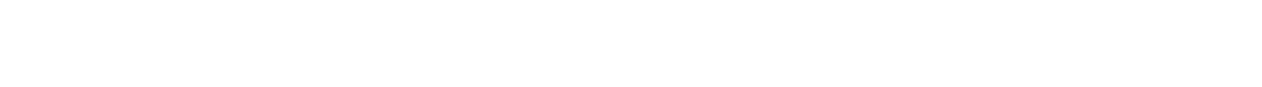

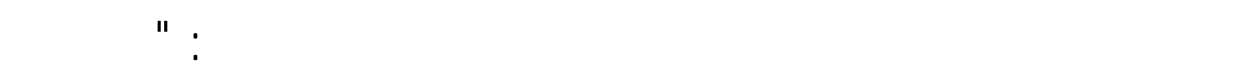

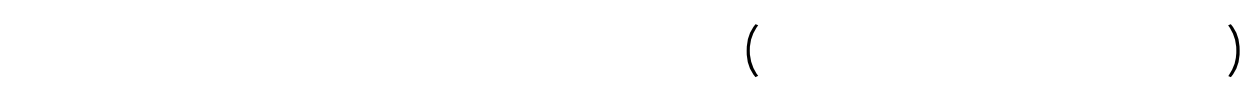

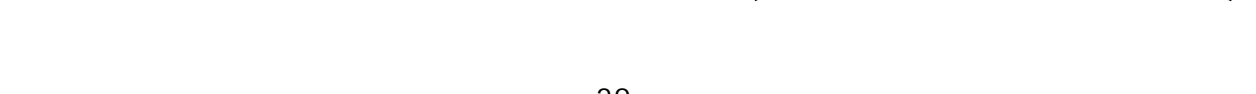
لأن كلى ما كل حقا كل القطل به علمأ. 38

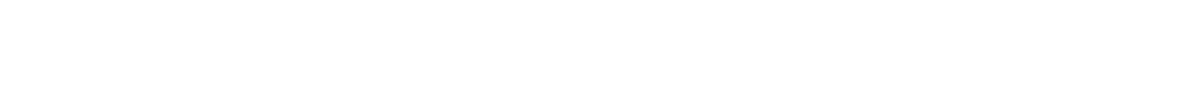

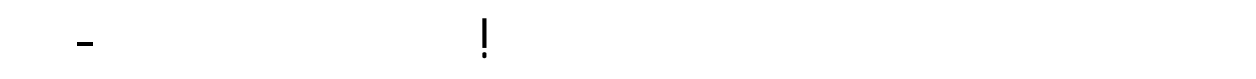

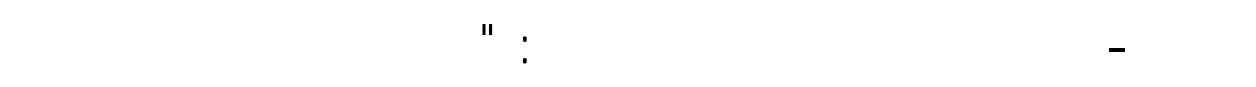

38 الرازي، الفسلـ الكبل، مرجسلق (173/5). 


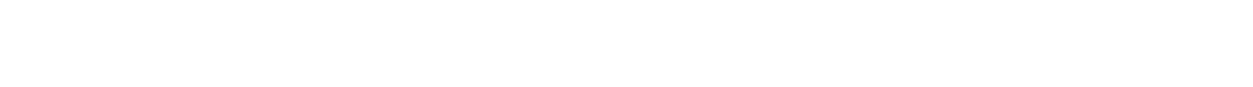

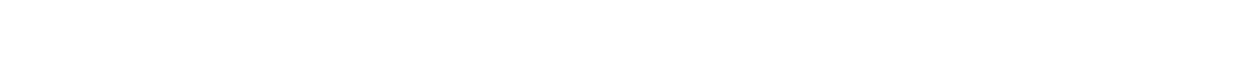
والمكرات، وهنه القدرة طالكة معلومة الثبوت بالضرورة، وزول الموانع والعولق

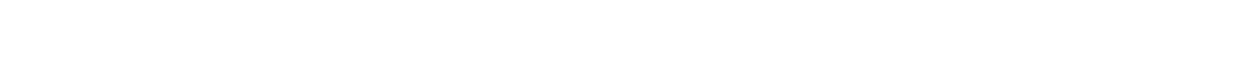

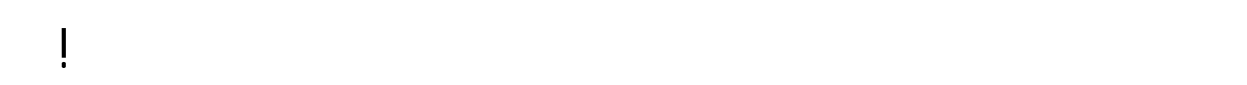
口المة البالهة عليكم".

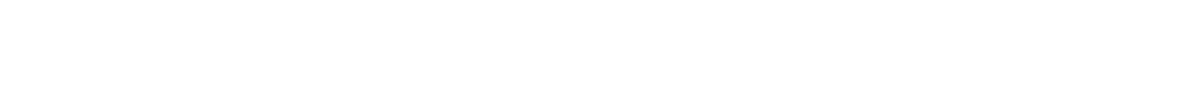

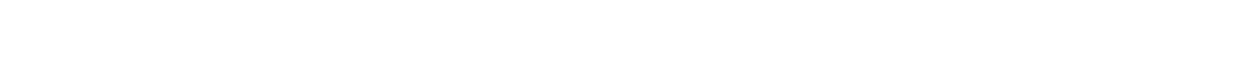
ومتبهون لأهوائهم، وني هذه صفة فلا تقلشهانة.

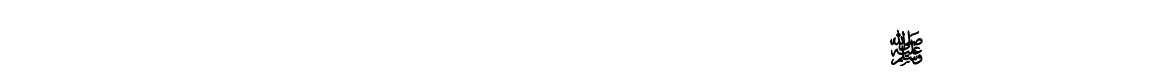

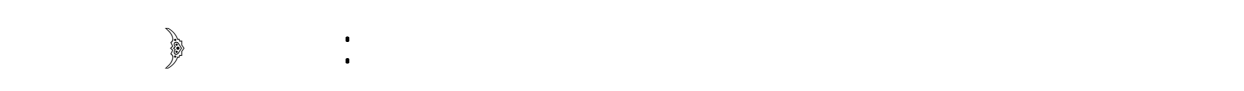

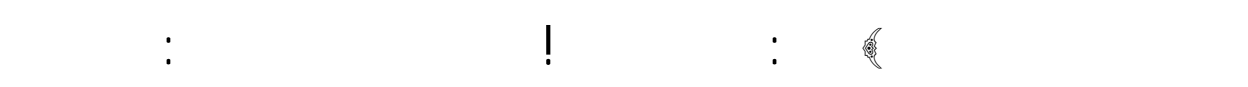
国 40."

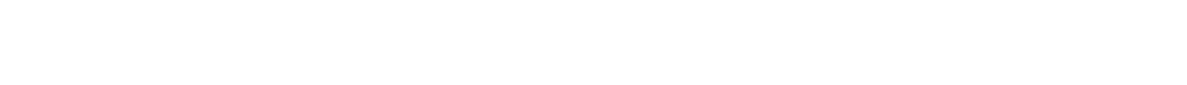

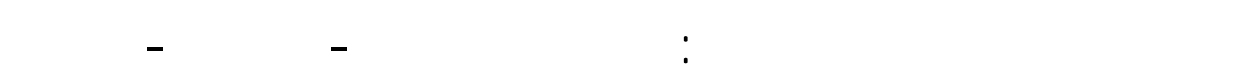

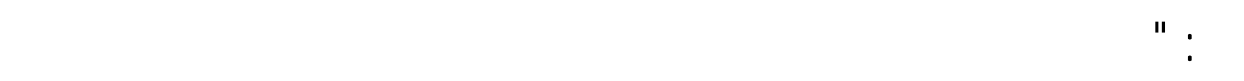

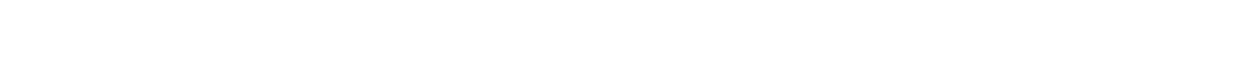

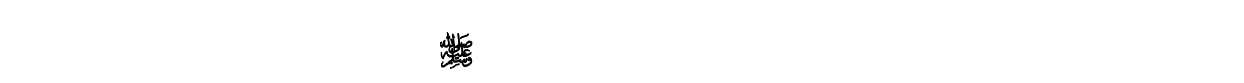

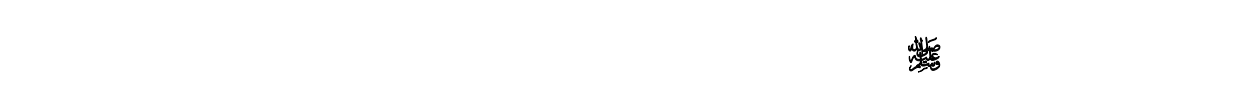

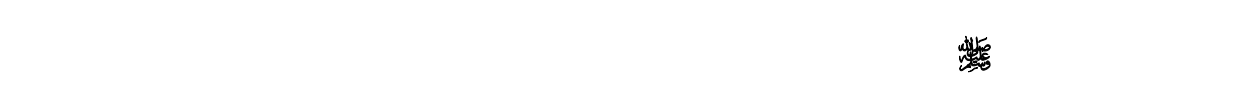

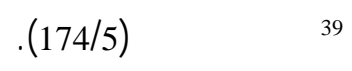

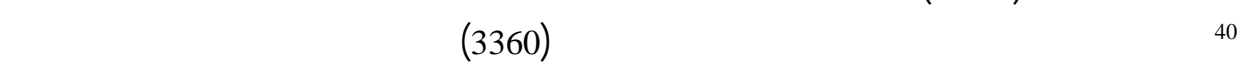

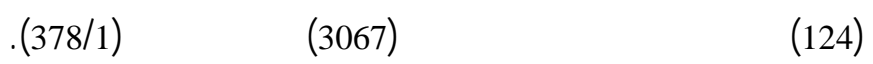




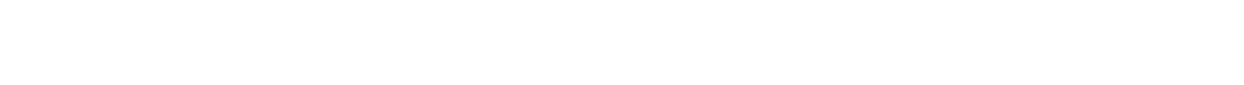
لا يريك".

\section{2 - الرد إلمالسة:}

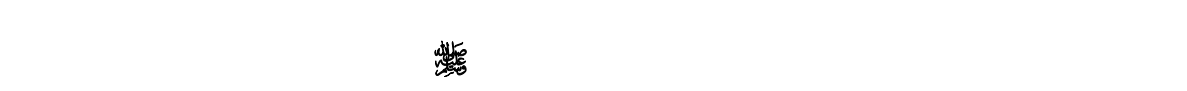

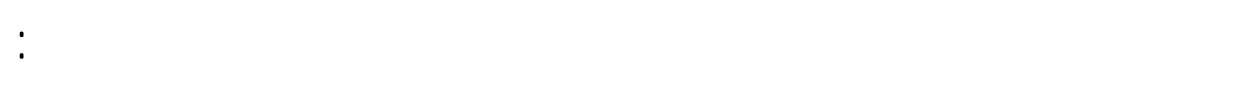

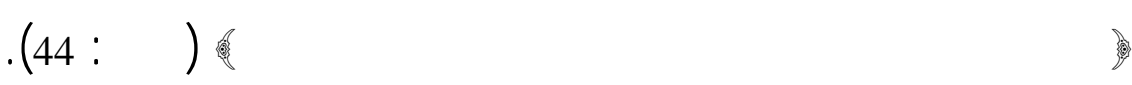

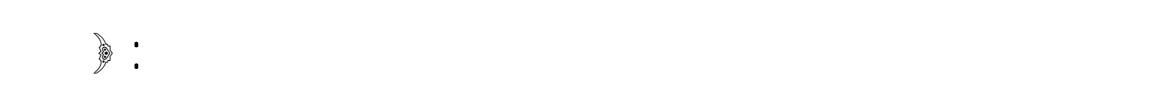

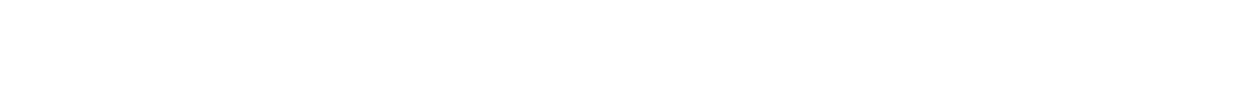
"المل البه (النساء: 59).

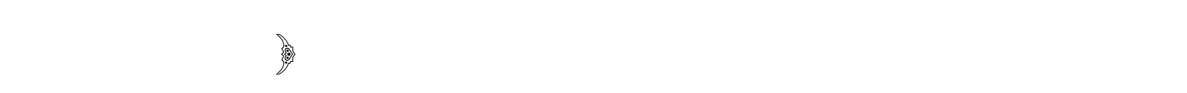

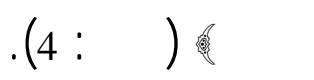

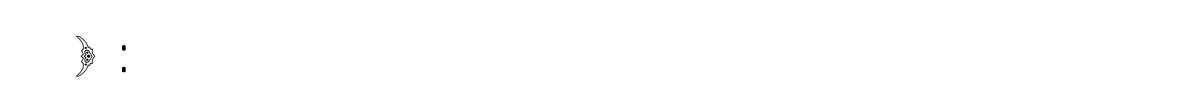

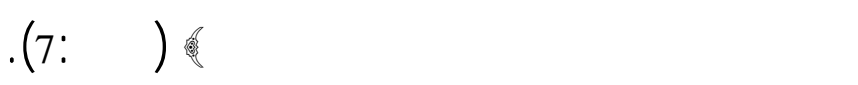

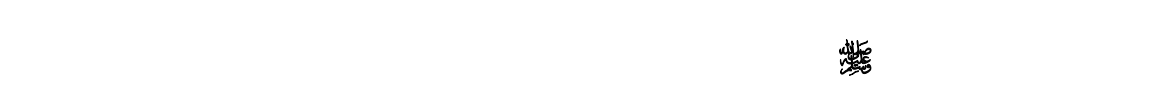

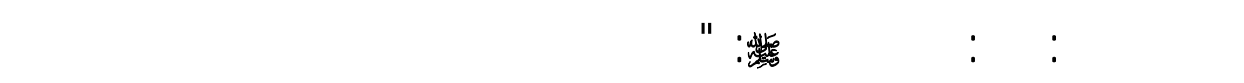

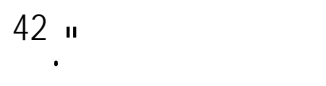

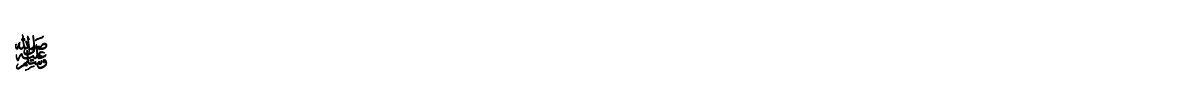

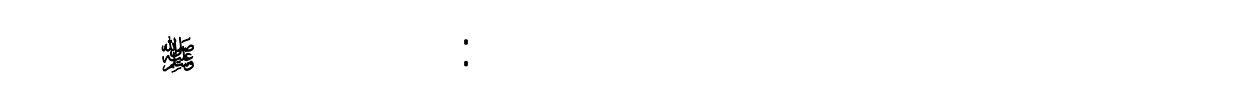

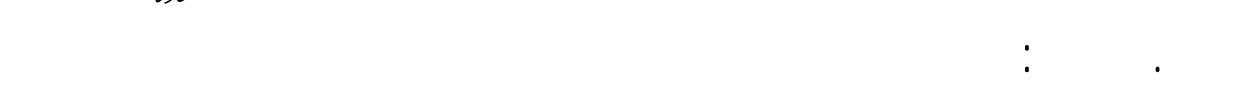

41 أخرجه النسائي، السن لمغرى، كنا آداب القضالة (5379)، قل النسائي: هذا حيث جيد، جيد.

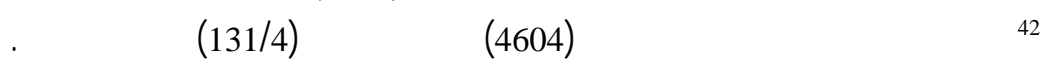


J

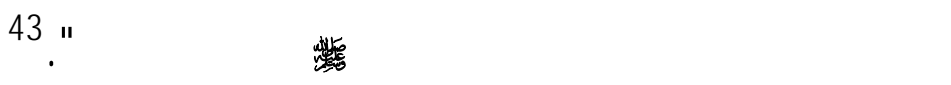

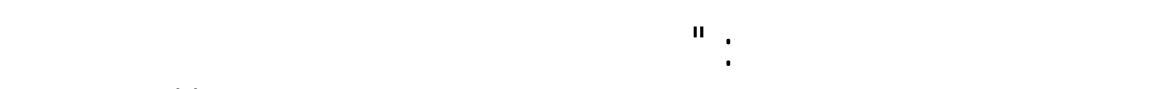

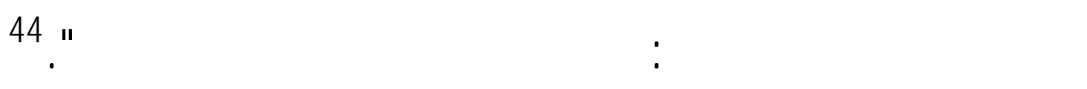

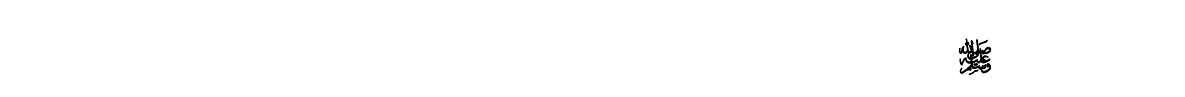

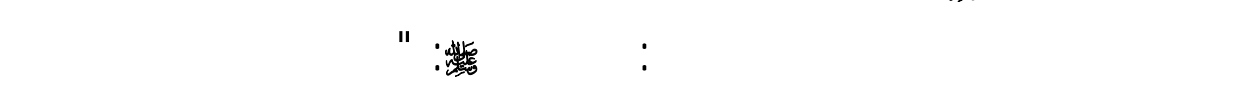

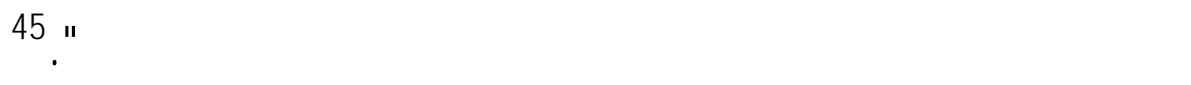

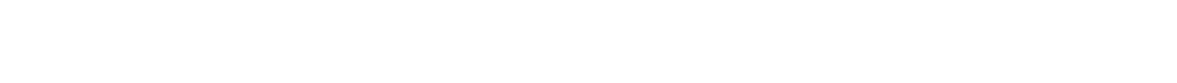

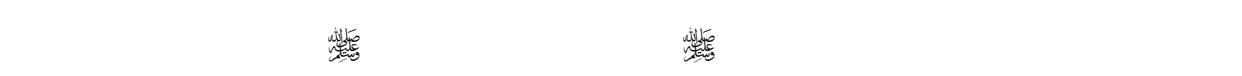

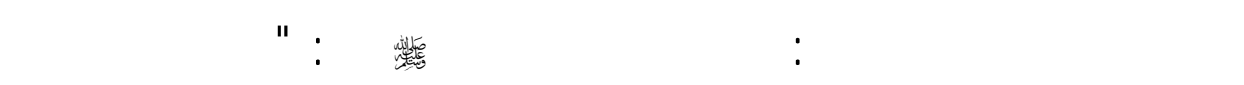

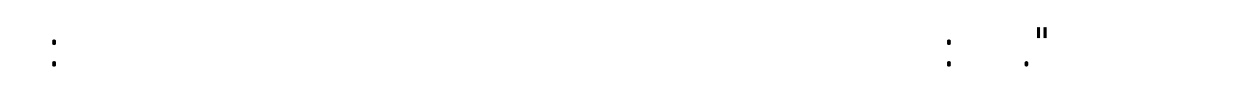

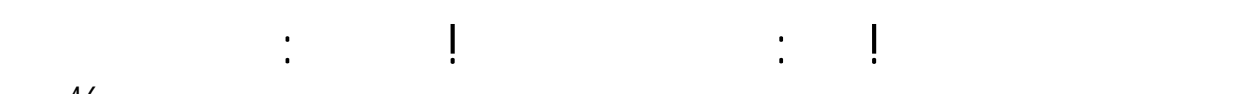
"46.

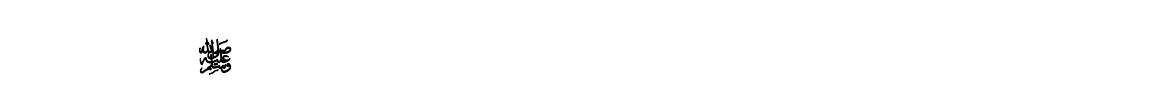

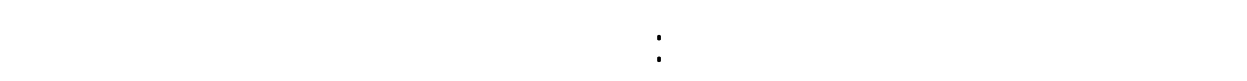

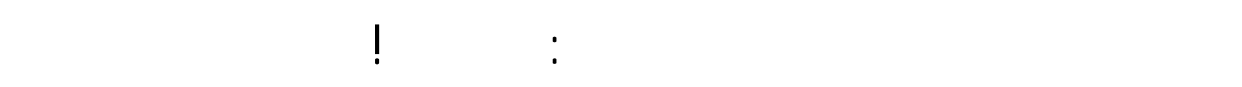

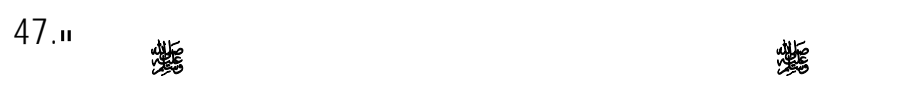

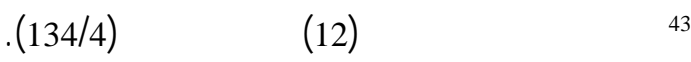

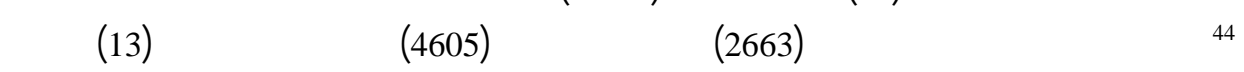
. 80 .

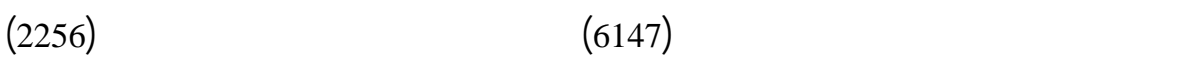

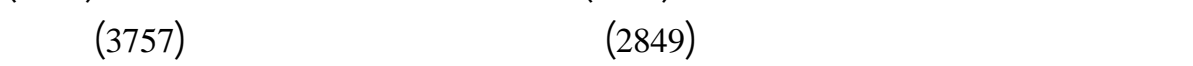
.

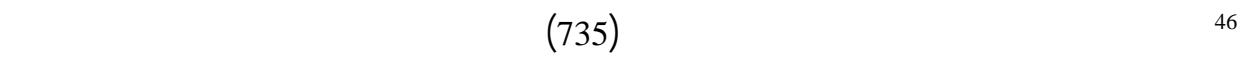

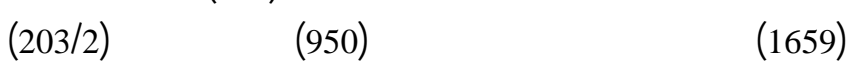

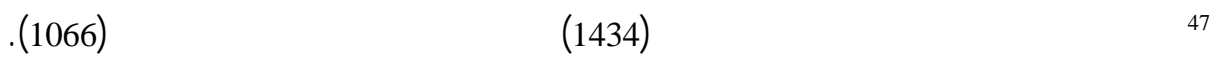




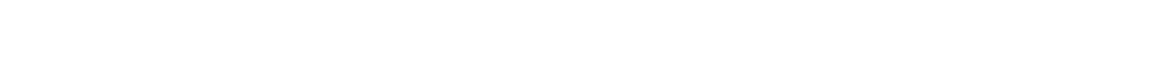

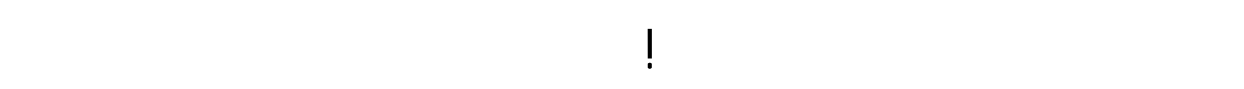

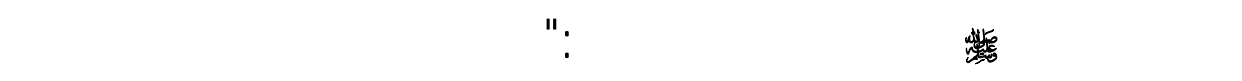

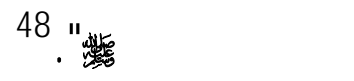

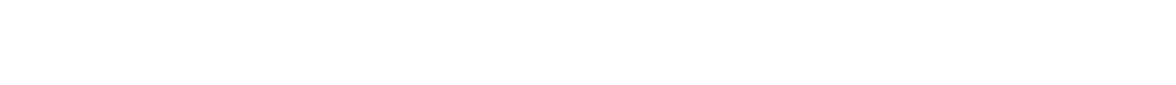

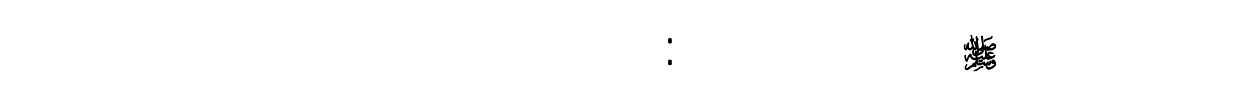

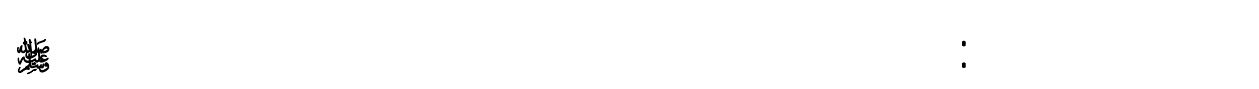

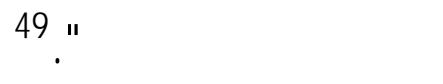

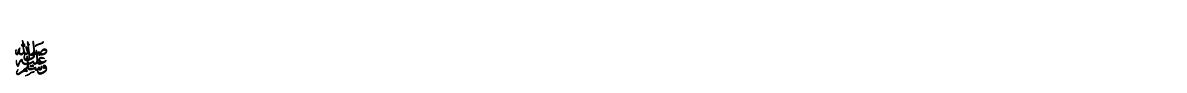

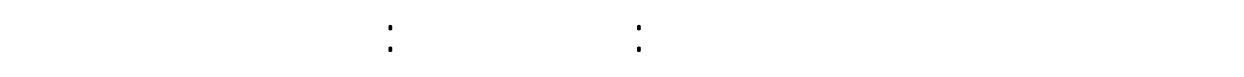

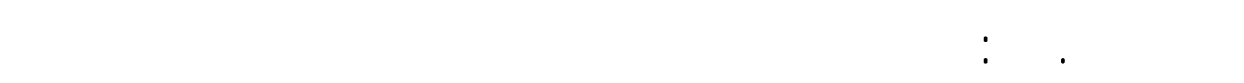

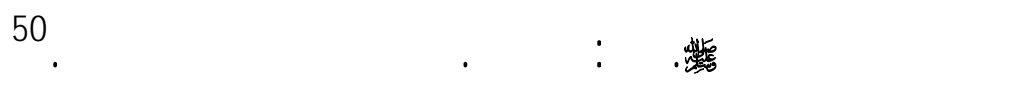

\section{3 - الولع الهمون:}

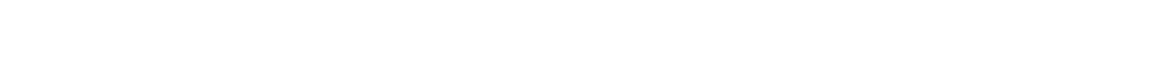

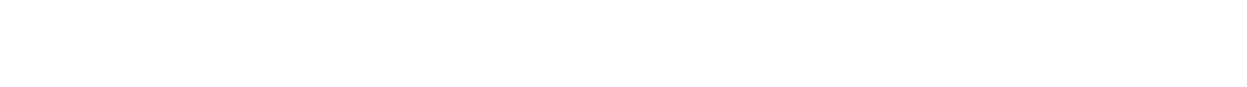

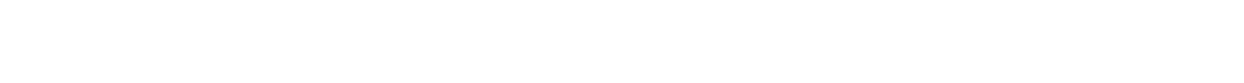

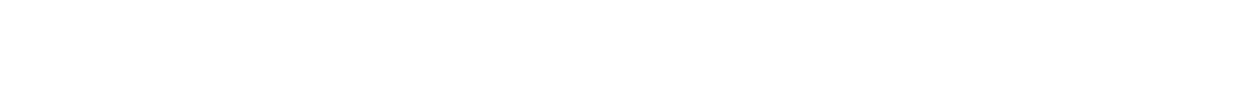

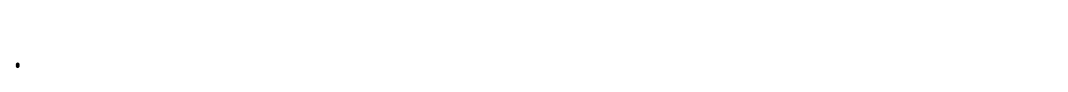

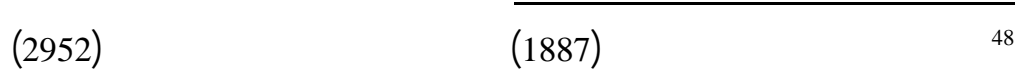

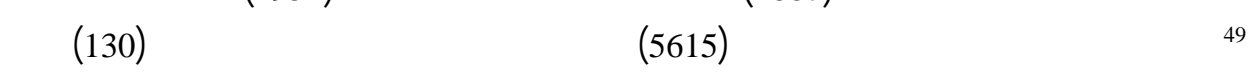
داود، المنن ، كناب الأشرة (3718) .

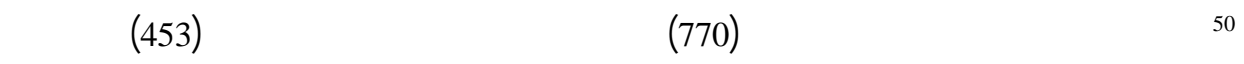

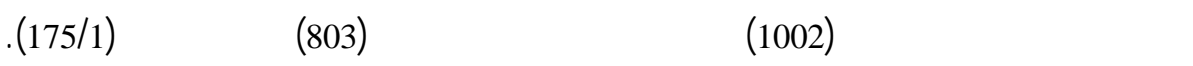




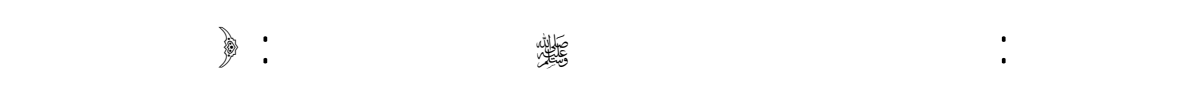

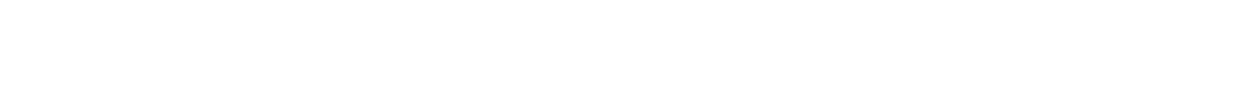

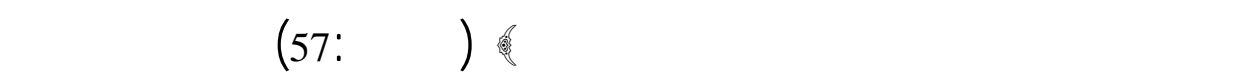

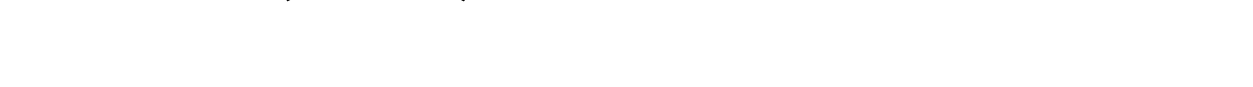

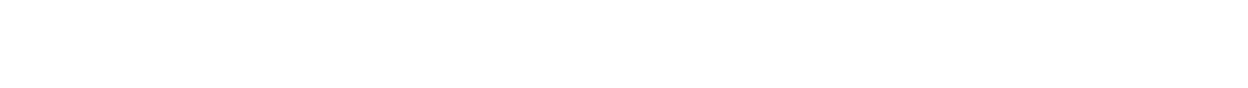

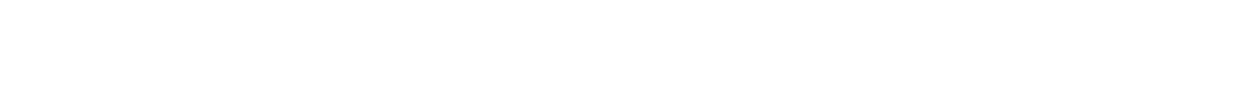

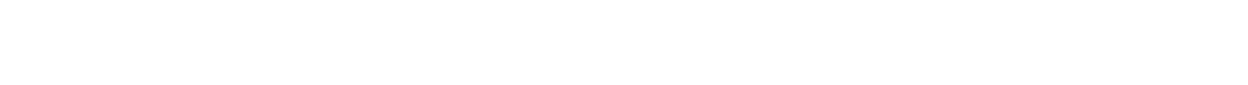

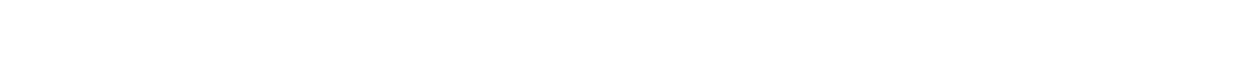
والاغتيل من حول الصهم حسبظنهم وزعمهم.

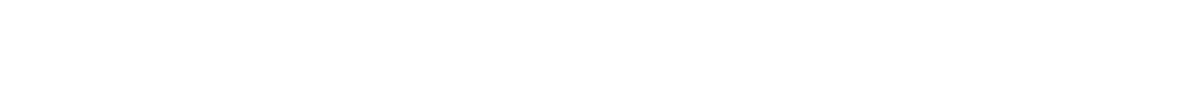

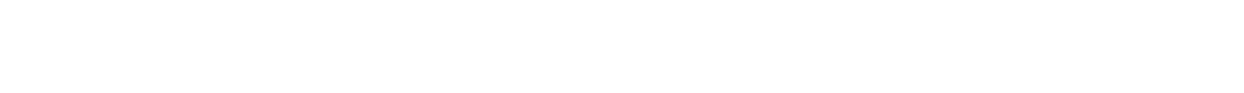

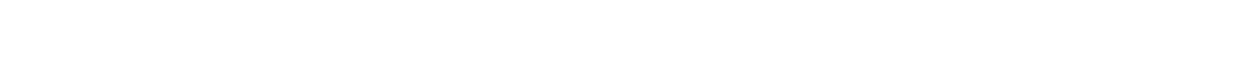

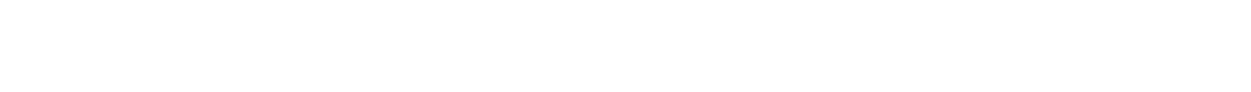

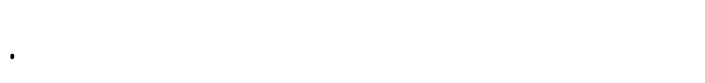

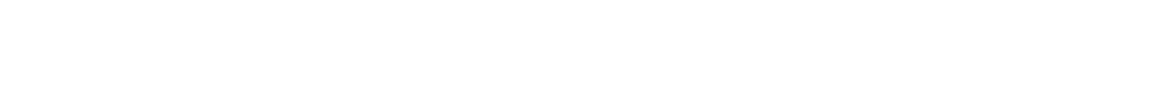

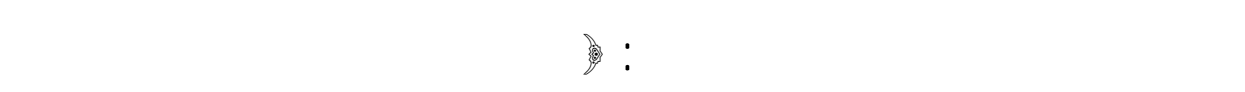

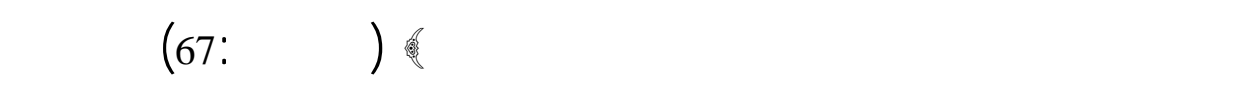

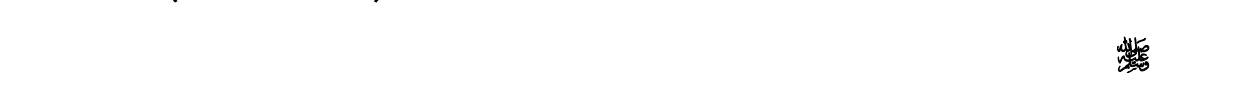
صحيح، والوأع يكنه.

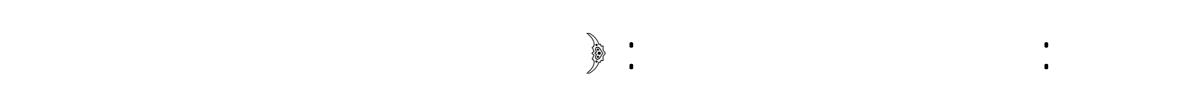

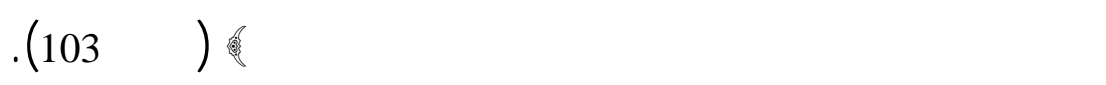

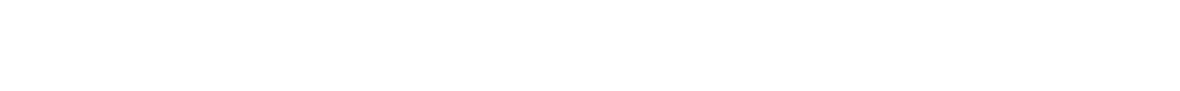

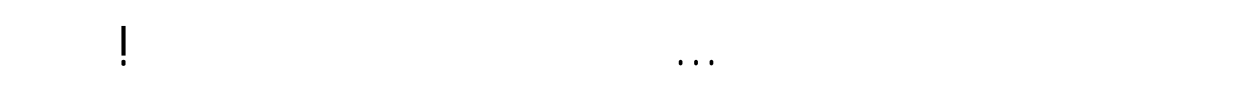

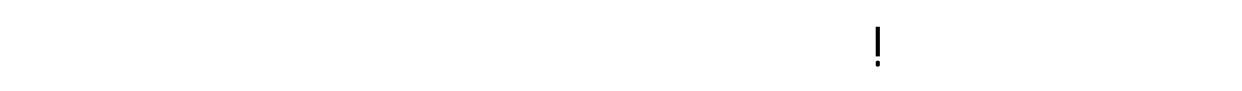




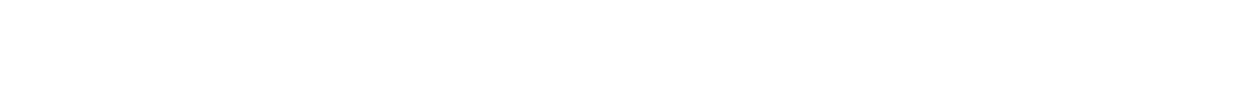

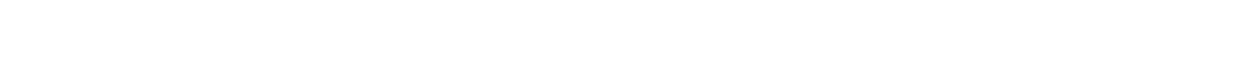
جاءلذا الإعجاز!

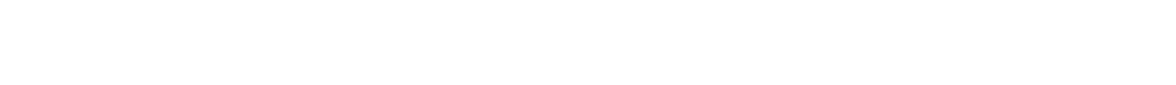
政

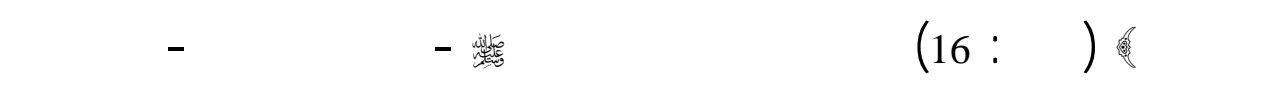

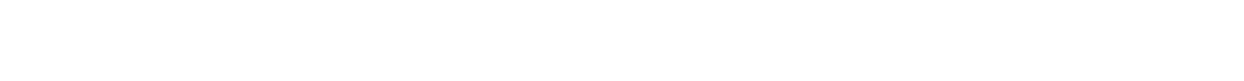

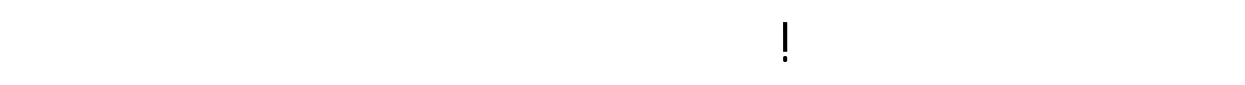

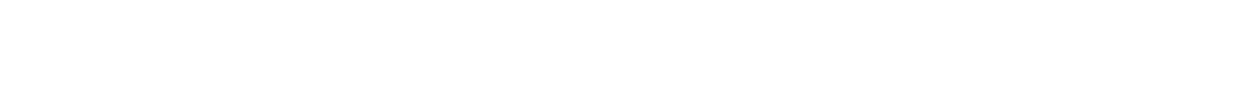

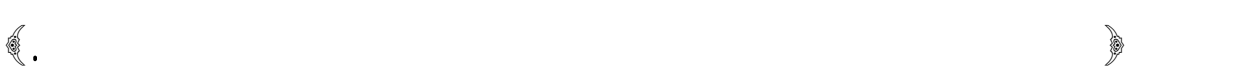
(العنكبوت: 48). (اله ).

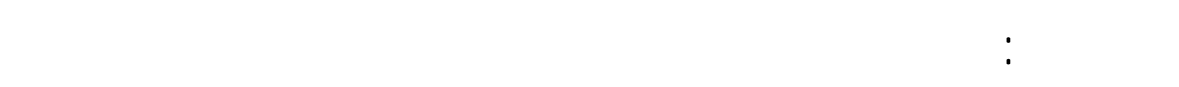

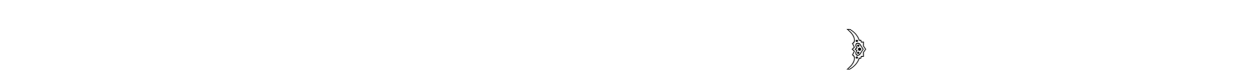

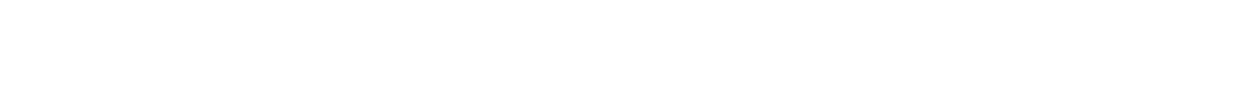

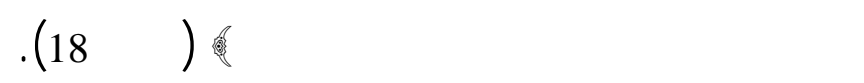

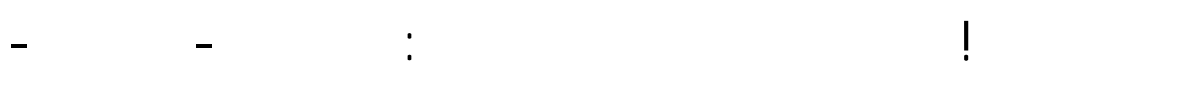

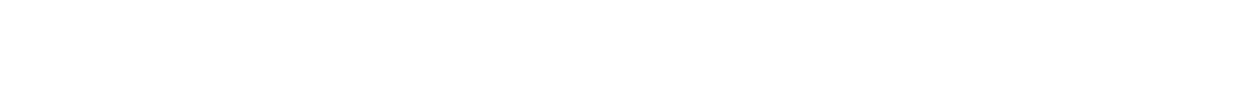

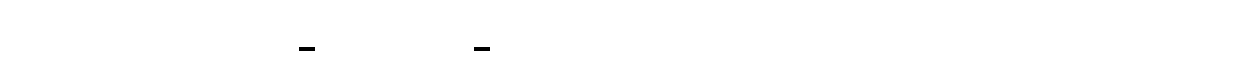

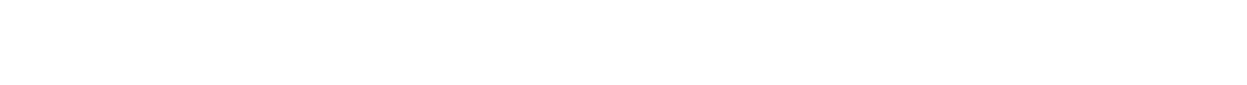

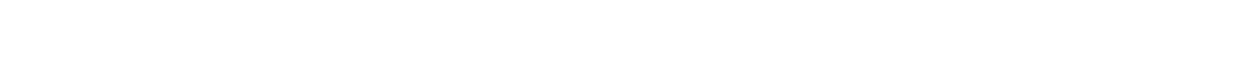

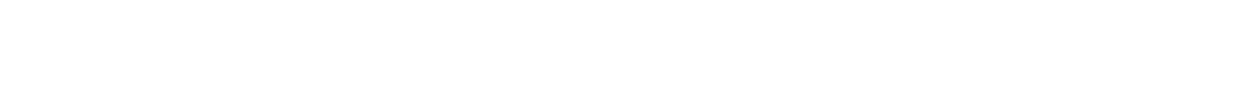

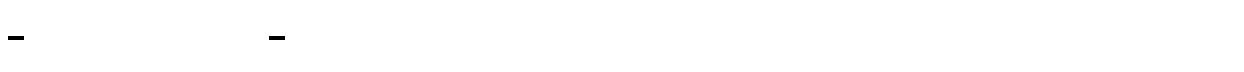

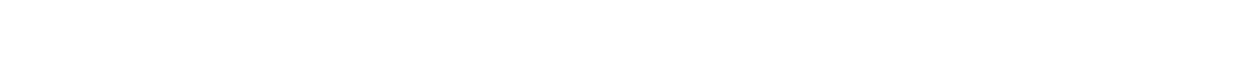




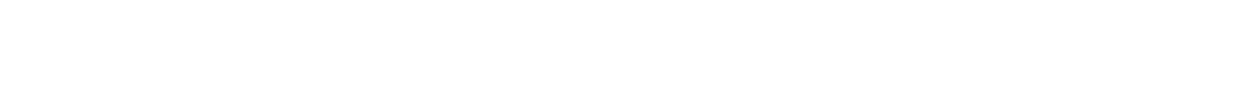
مقالة كذب وافتزاك وزيف.

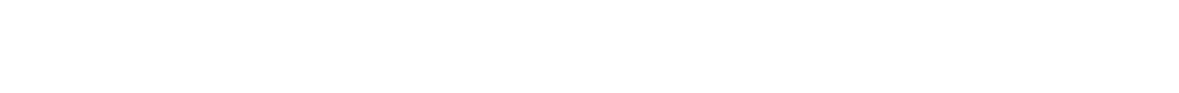

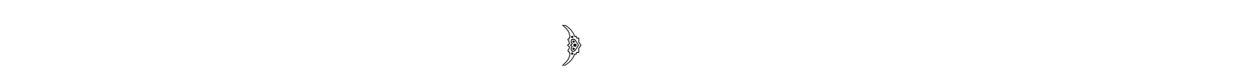

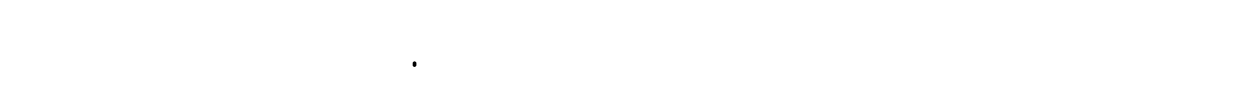

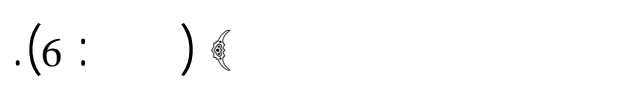

وجاء الهلب الإيلي، يضخح مقالتهم ونواياهم، وأئم إن كانوا صاقولفليتمنوا

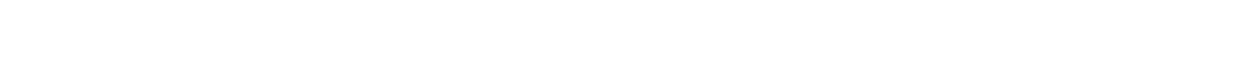

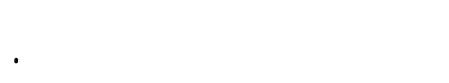

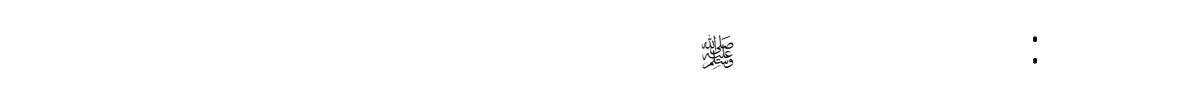

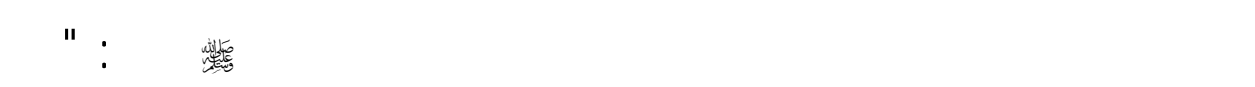

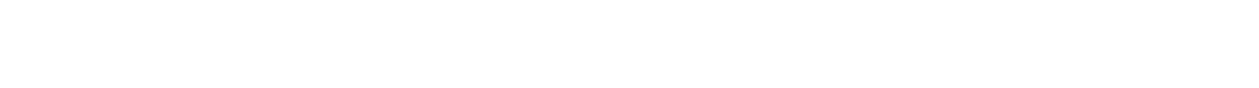

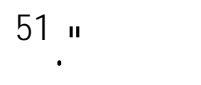

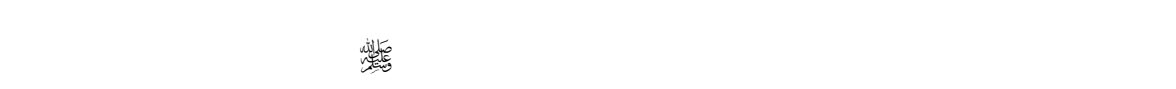

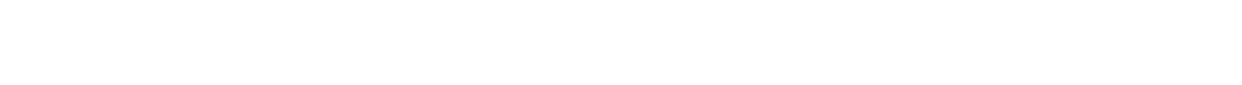

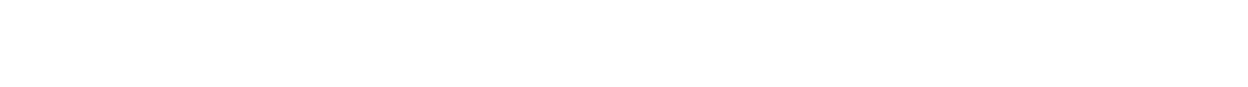

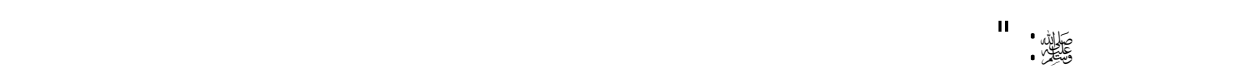
因

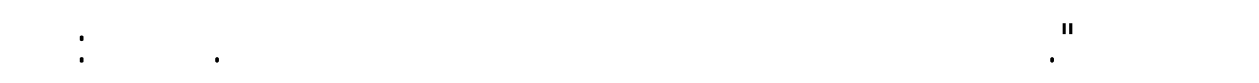

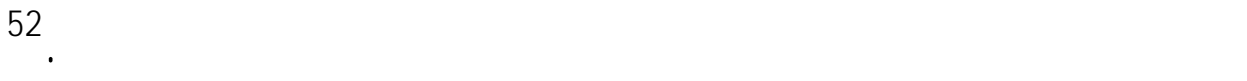

${ }^{51}$ •

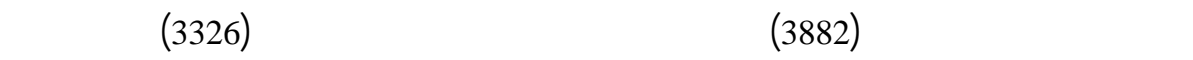

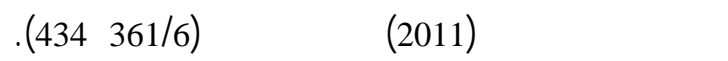

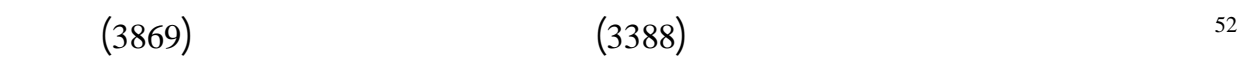

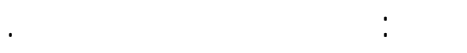




\section{4 - التالخ:}

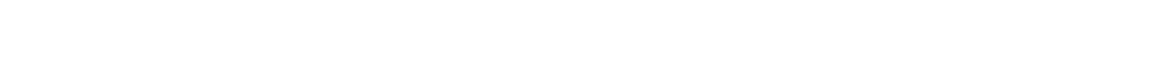

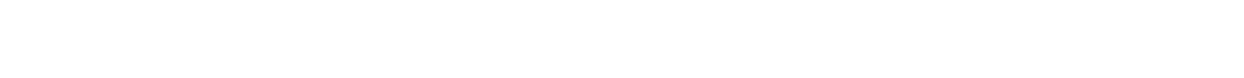

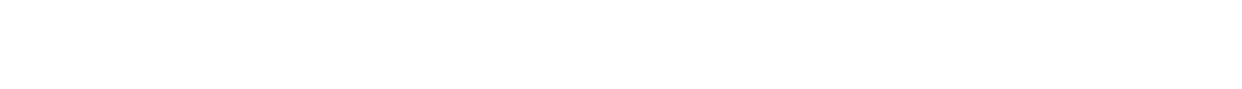

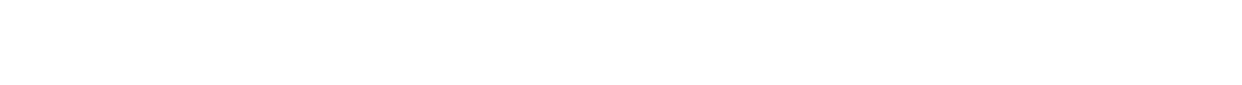
تارطا ماصقناها.

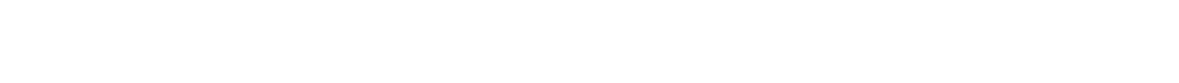

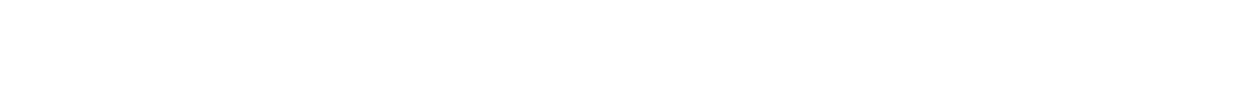

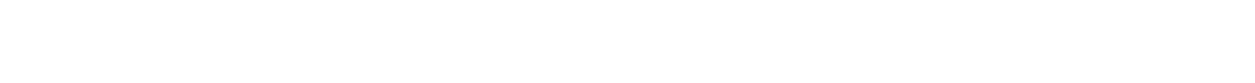
على كنمن الأحداث ولوقائع.

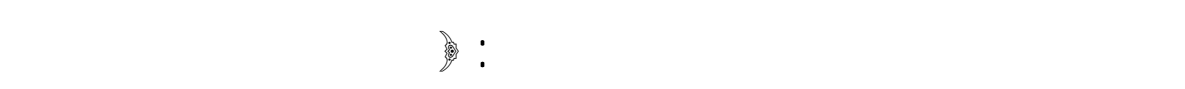
ف

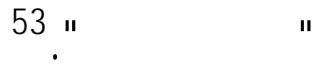

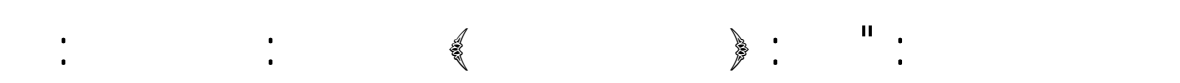

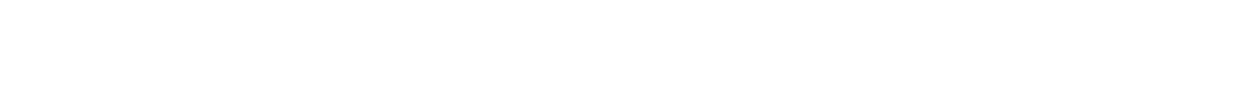

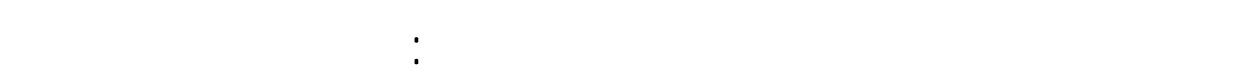

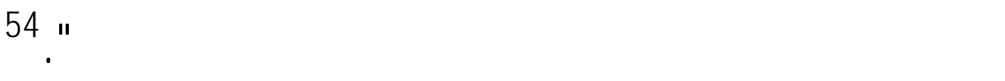

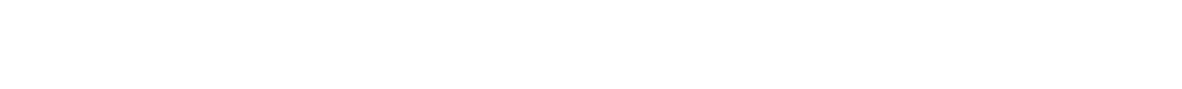

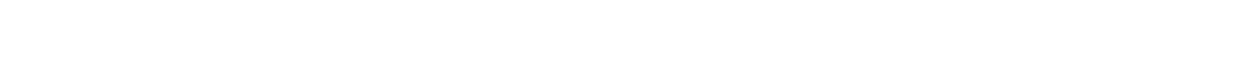

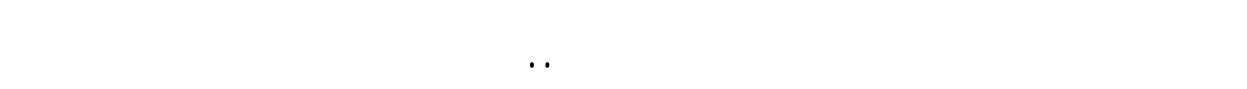

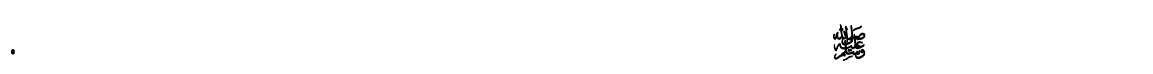

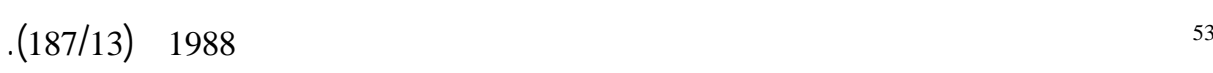
الرازي، الفسلـ الكبل، مرجعسلق (68/7). 


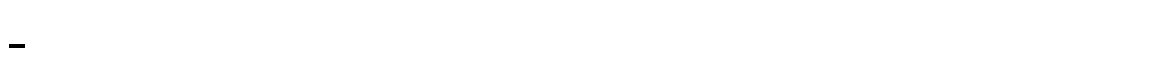

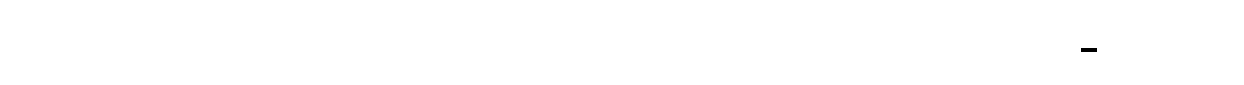

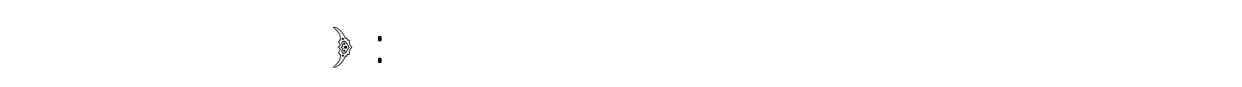

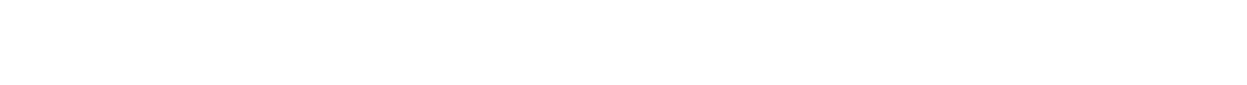

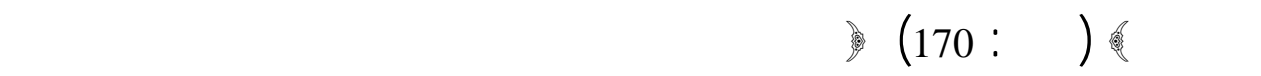

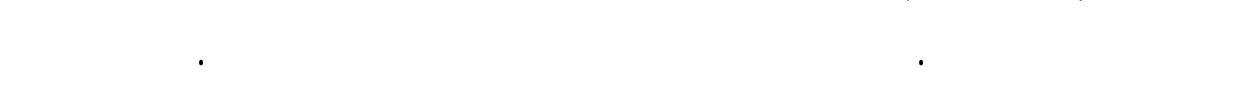

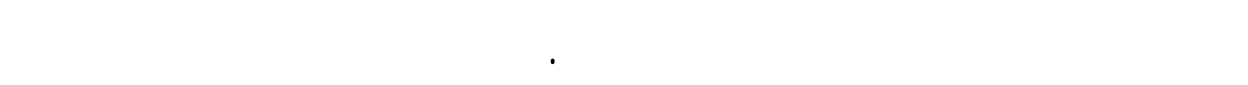

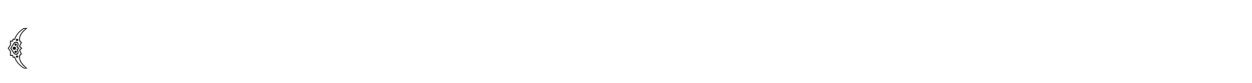

$$
\text { (الزخرف:22-23). }
$$

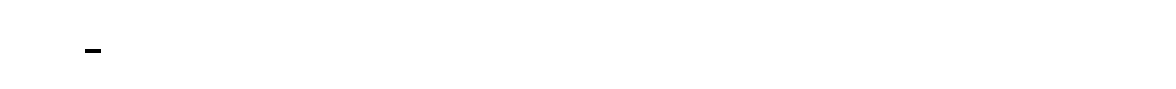

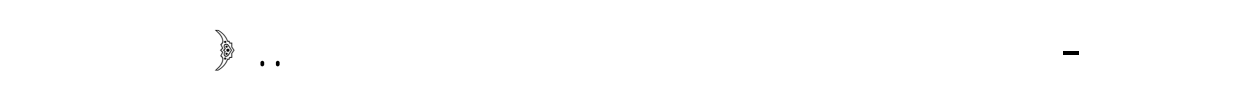
期

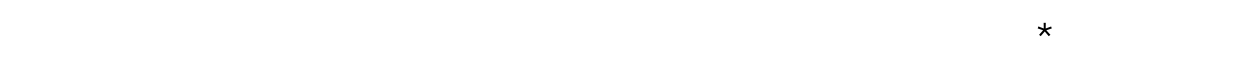

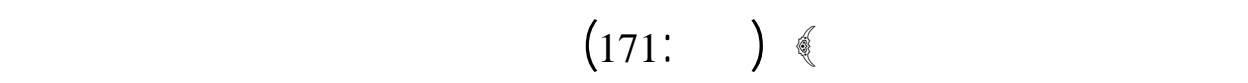

كالبغاوات دون ررلمة أولمحيص أو تفكلـا.

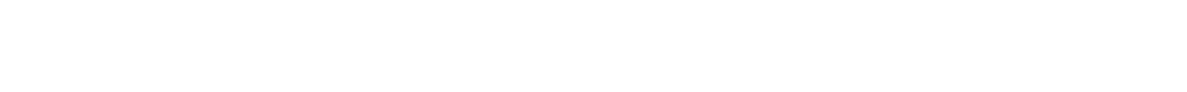

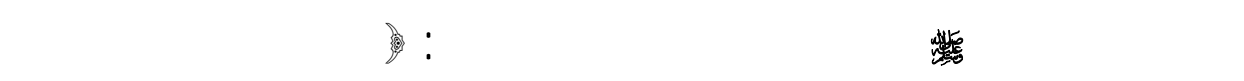

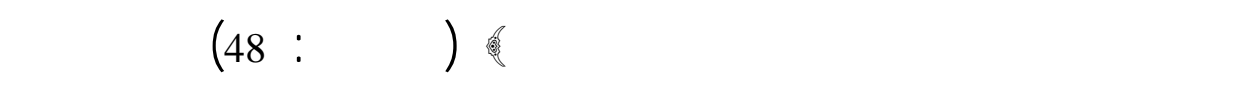

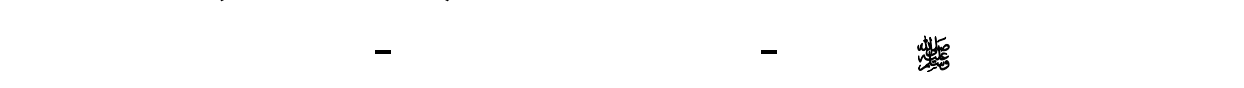

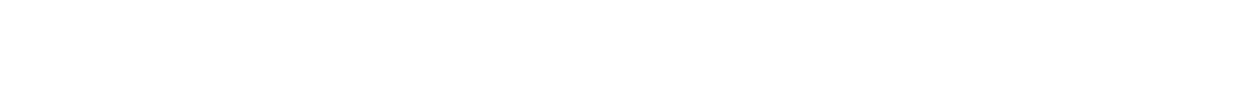

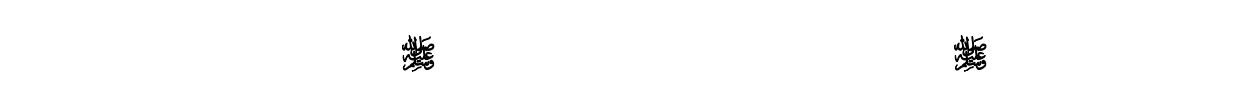

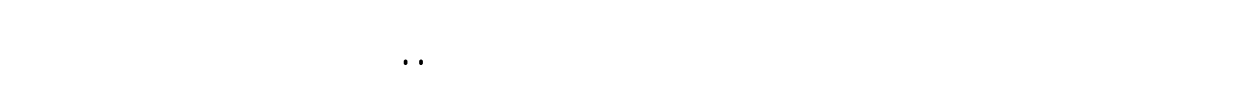

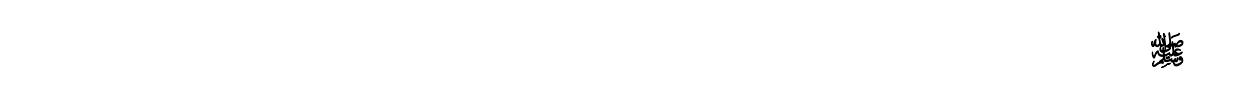

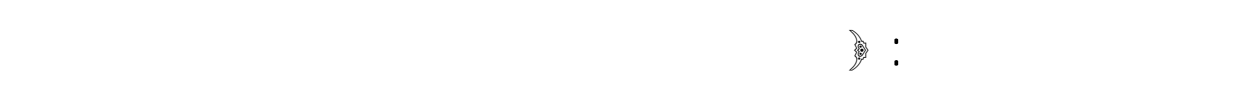

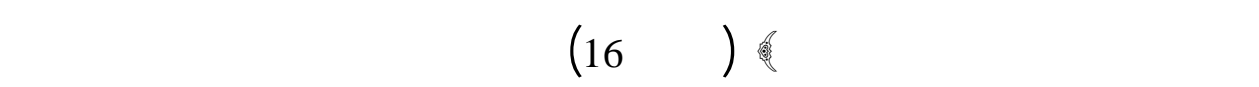




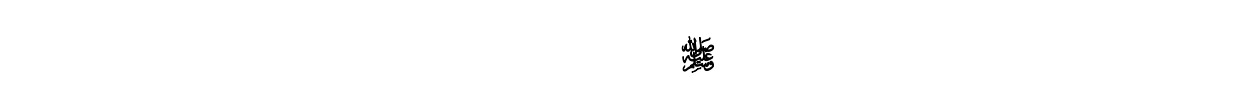

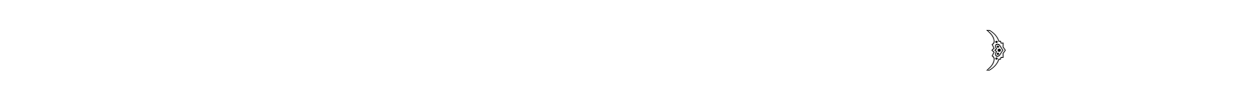

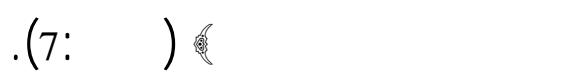

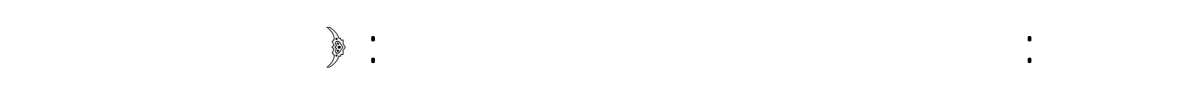

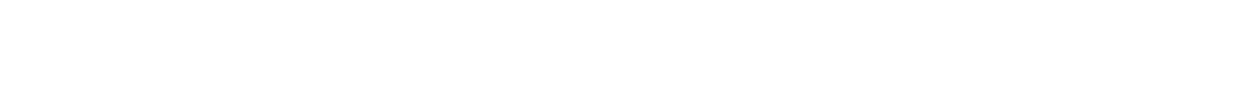

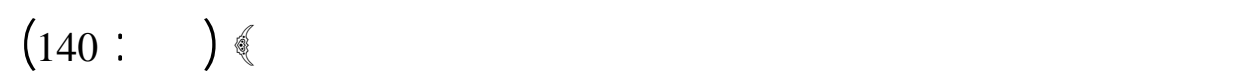

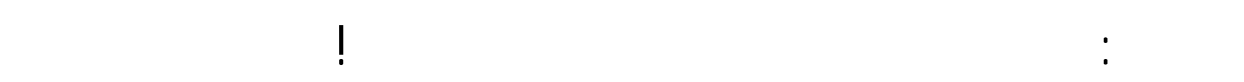

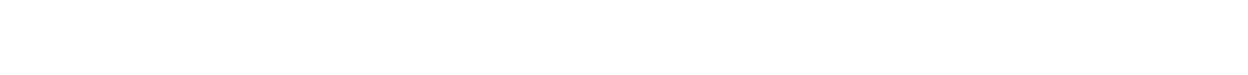

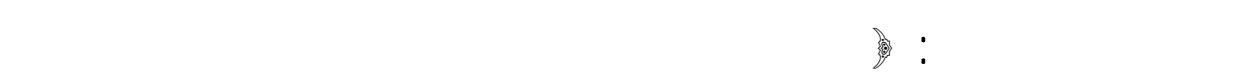
喟 若

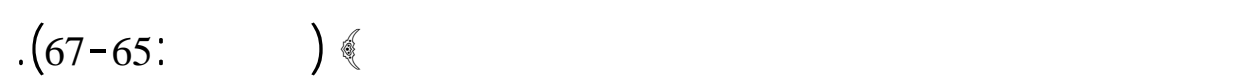

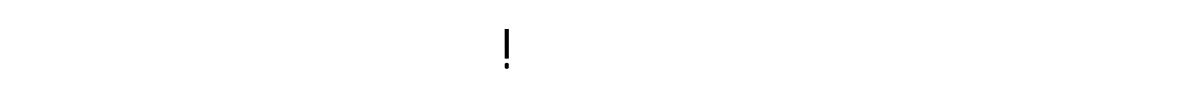

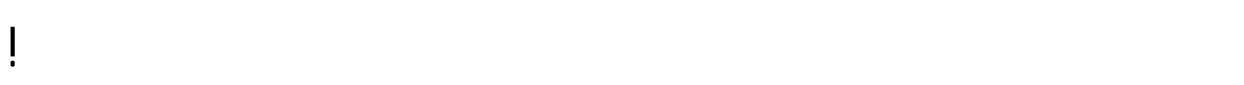

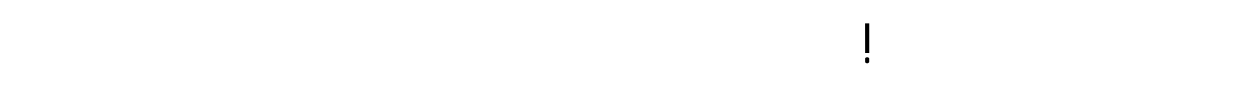

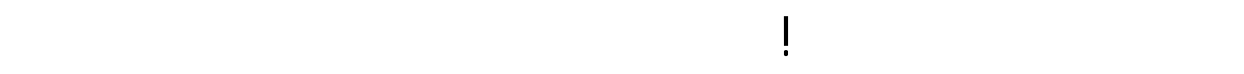

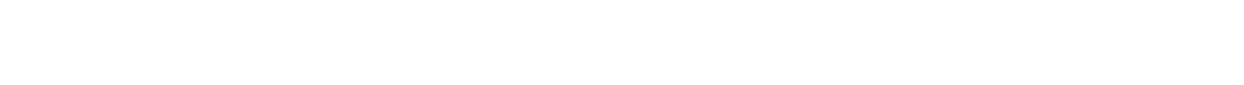

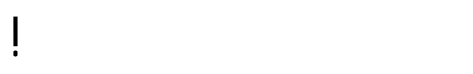

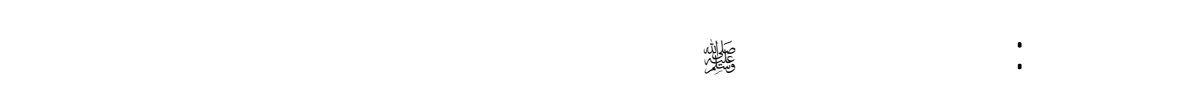

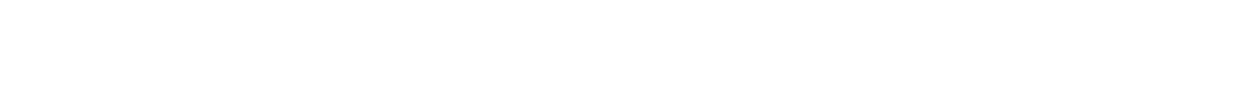

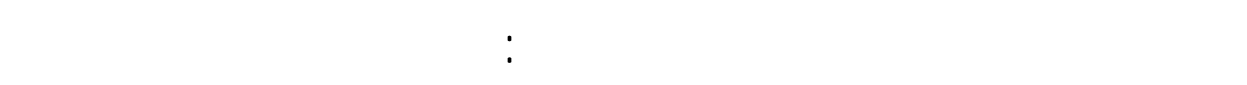

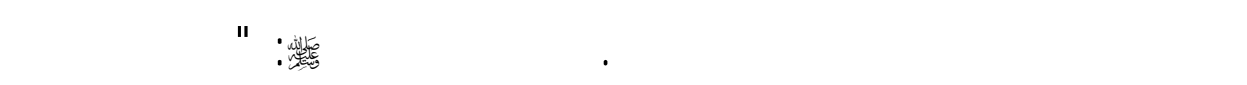

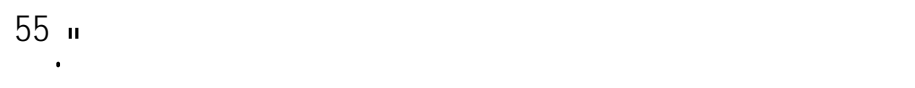




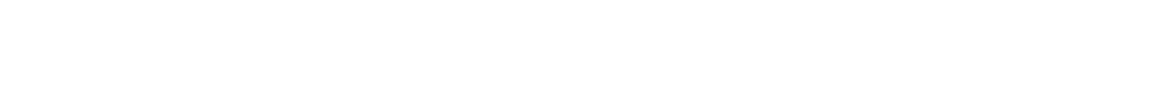

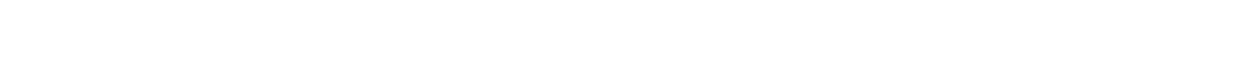

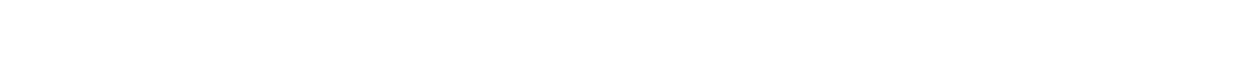

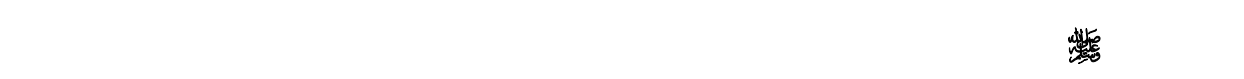

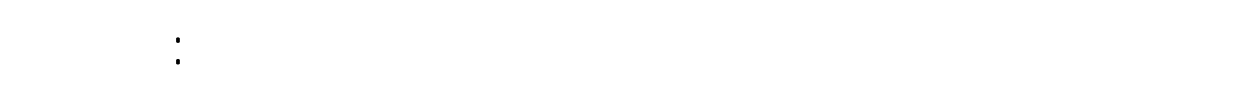

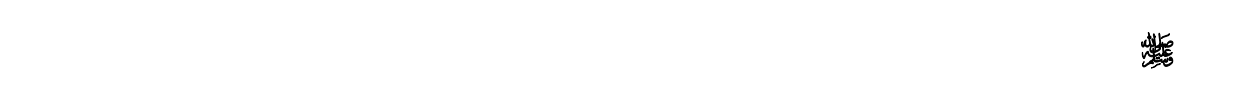

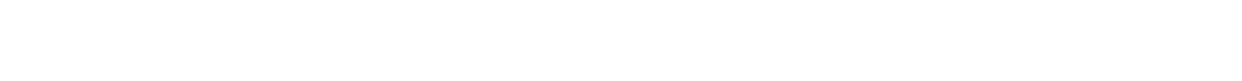

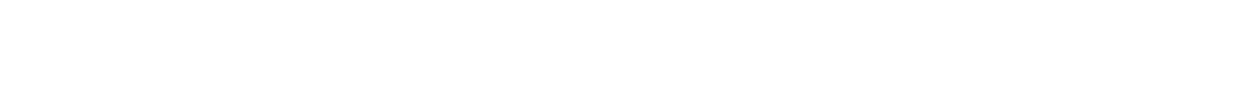

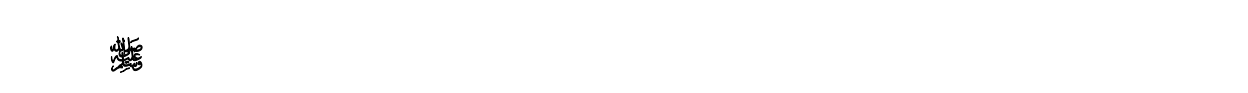
قَل

\section{- 5}

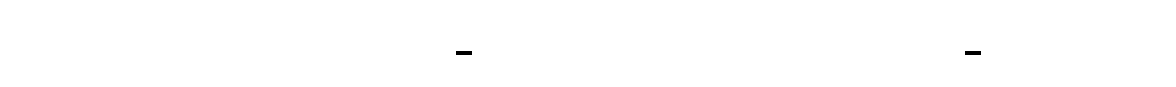

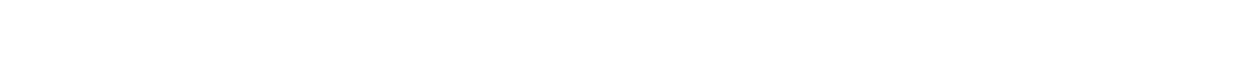

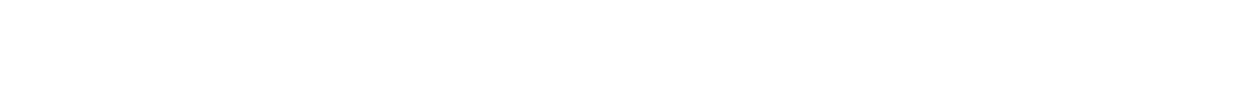

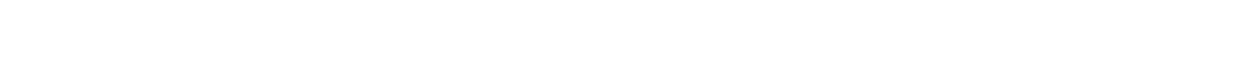

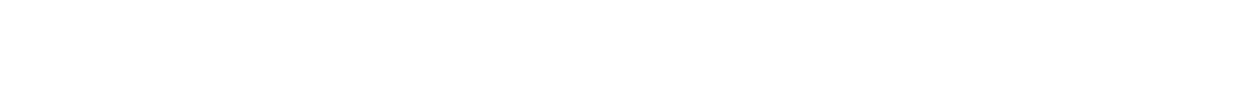

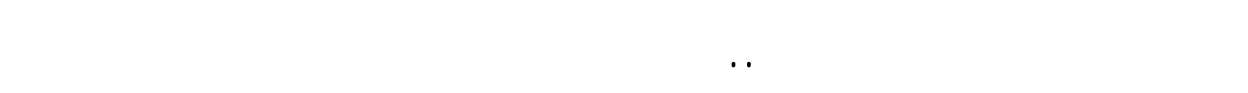

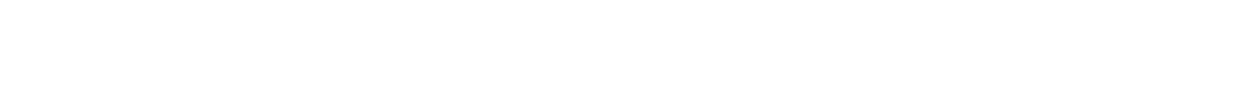

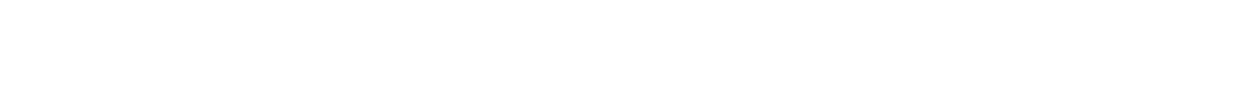

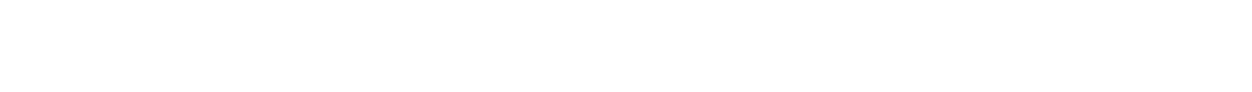

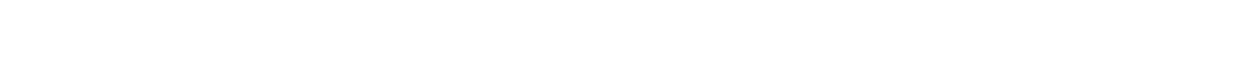

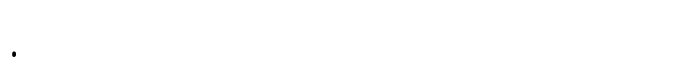

ون هذه الأمثلة: 
فايزعبد الفتاح أبوعمّا

178 لبلامية إلهرفة، السة النلنهة، العدد 39،شتاك 1426هـ/2005م.

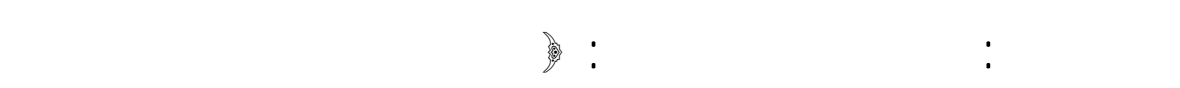
口

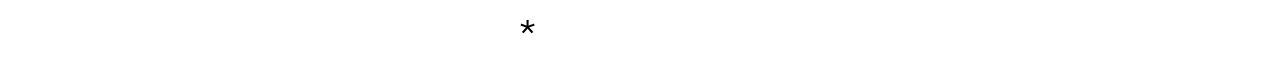
(10)

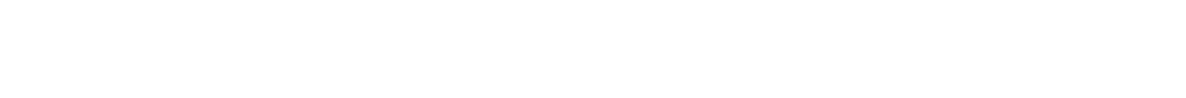

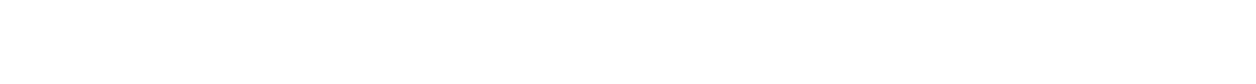

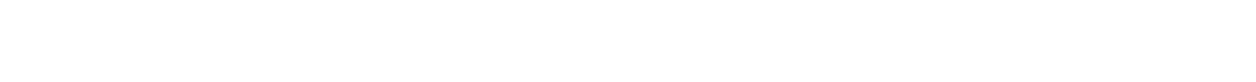

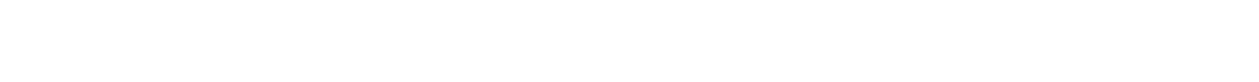

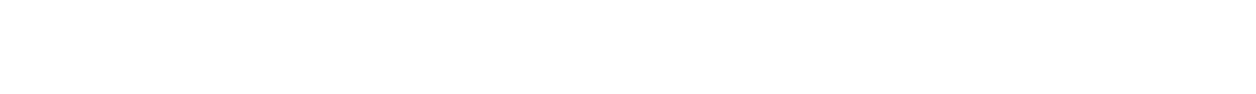

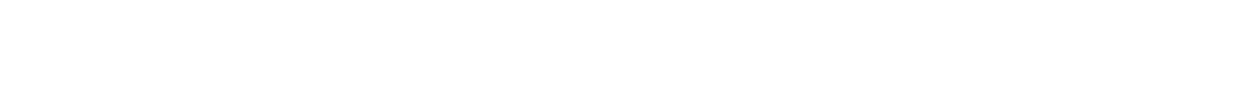

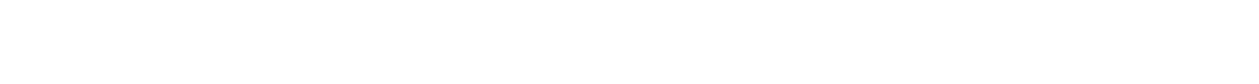

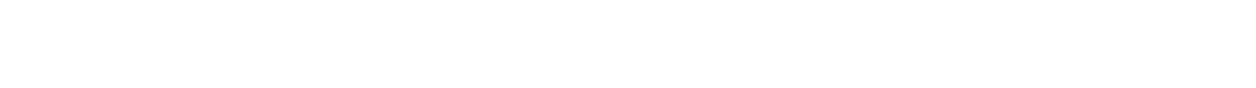

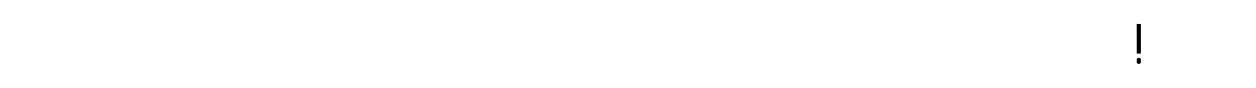

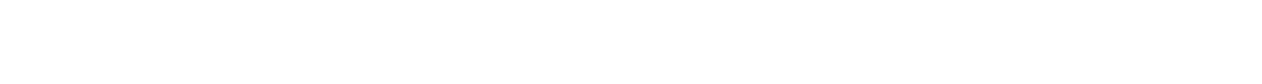

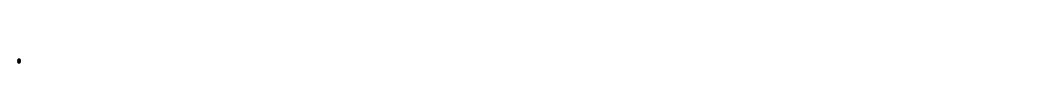

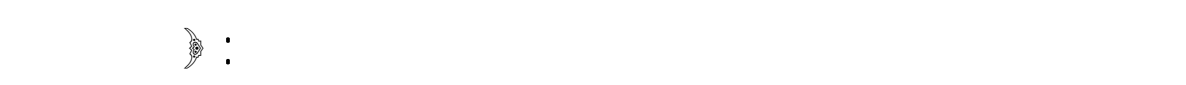

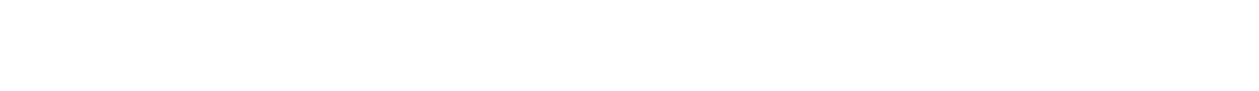
将

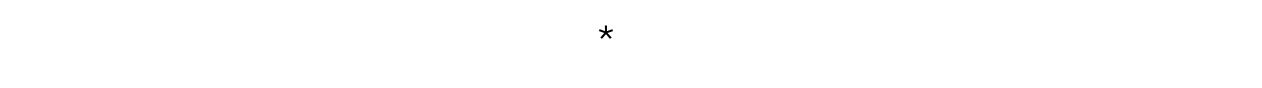
国

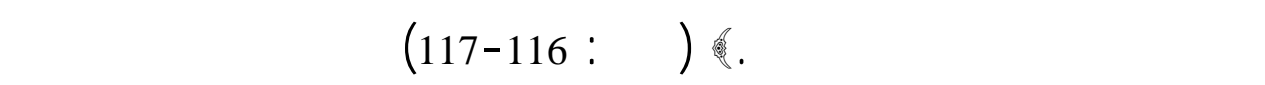

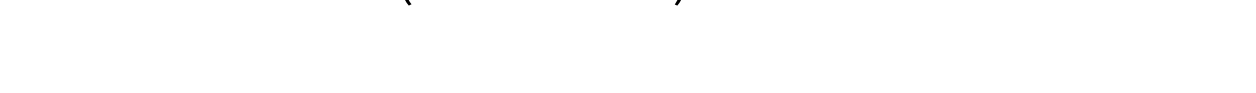

أُؤن تلالفوا الطرق الني سمهم وحياً. 


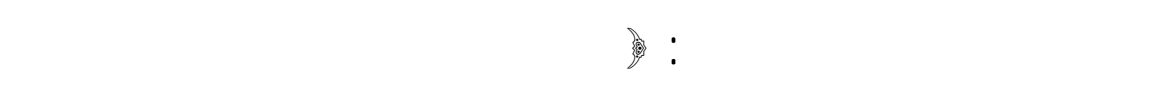

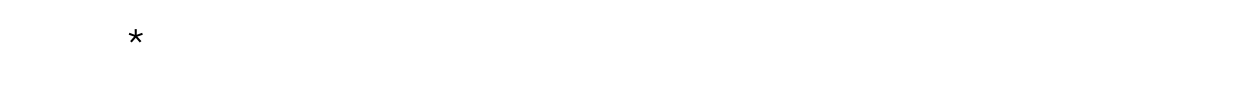

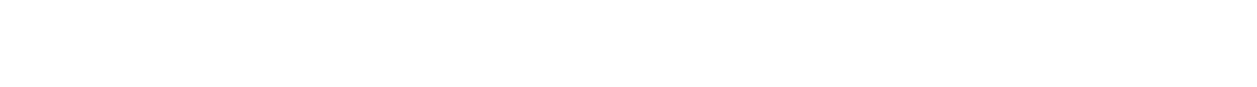

$$
\text { (29) }
$$

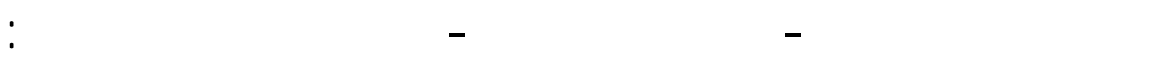

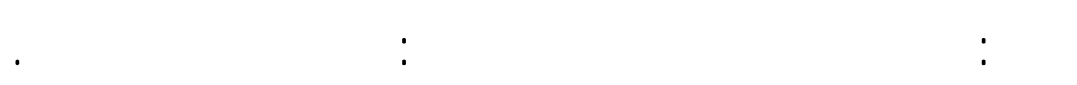

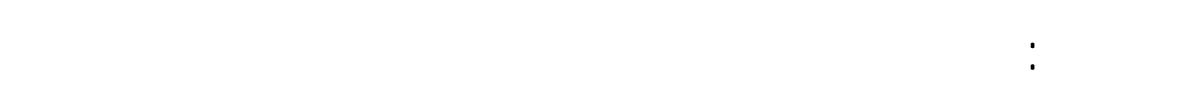

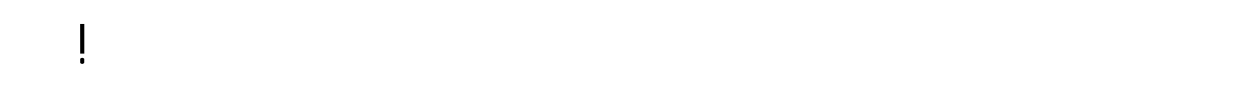

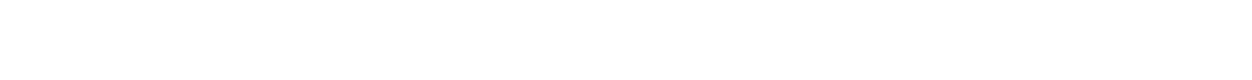

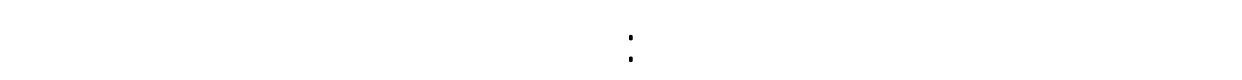

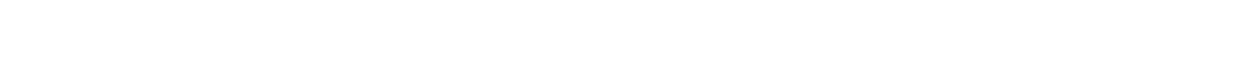

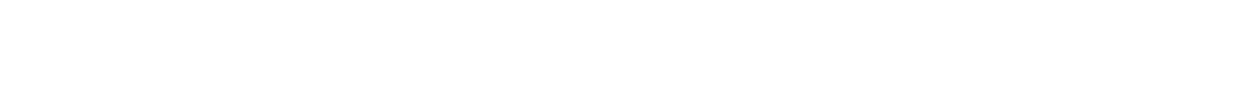

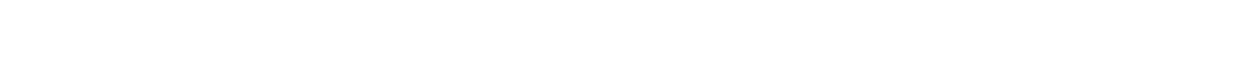
وجلّ ليطسب على ما لقتفت يده.

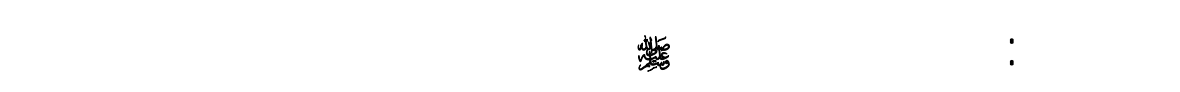

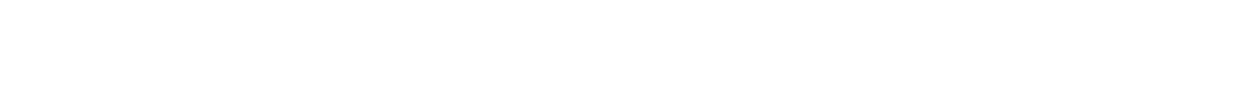

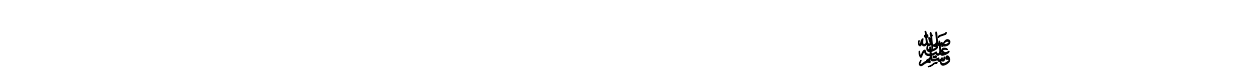

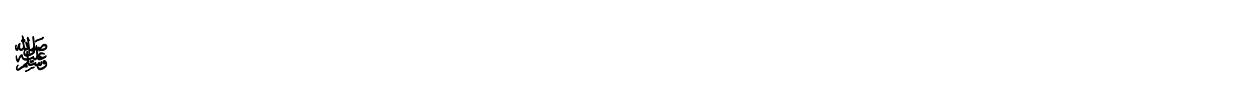

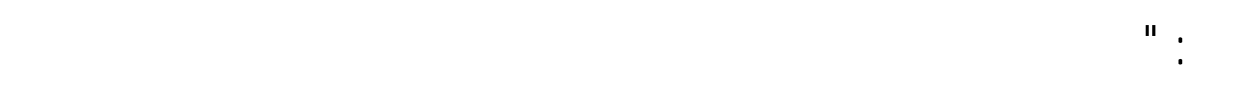

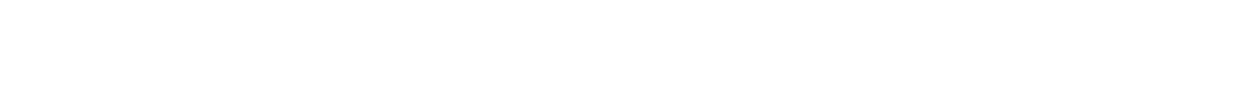
56 ."

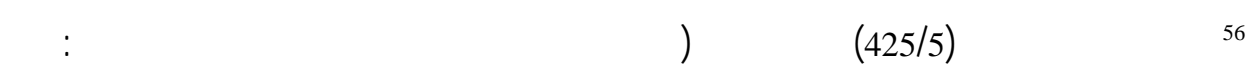

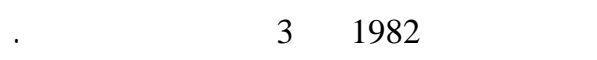




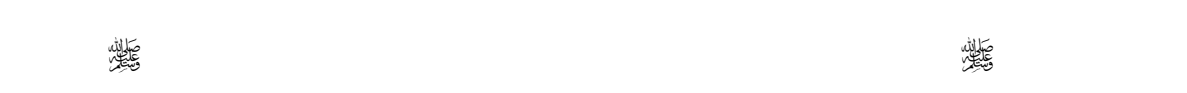

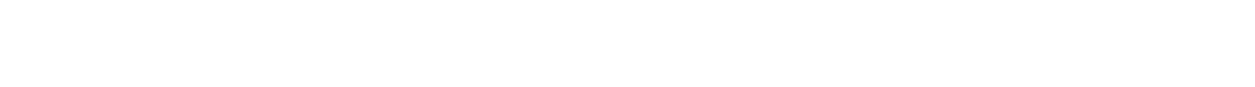

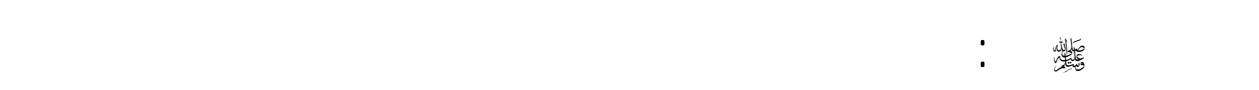

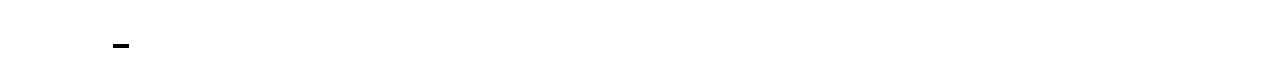

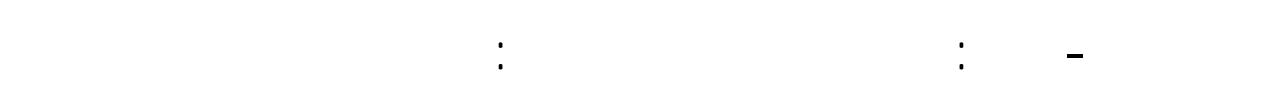

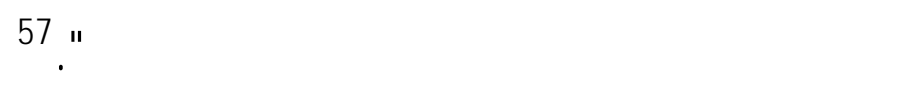

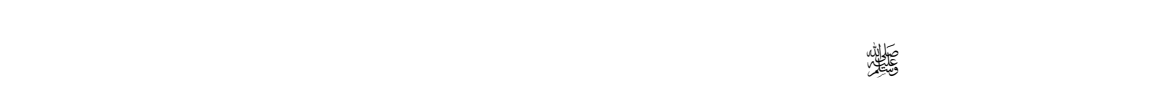

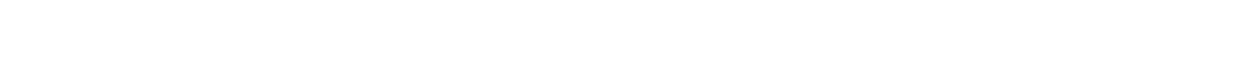

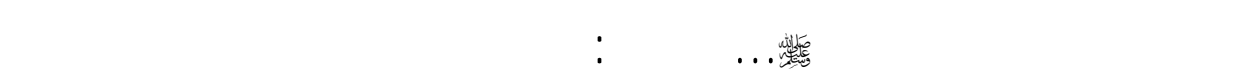

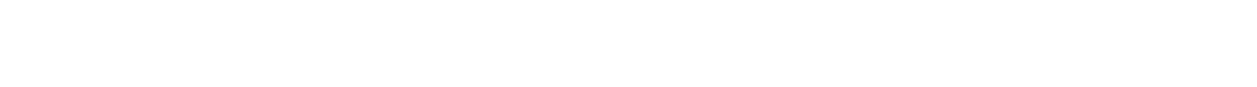

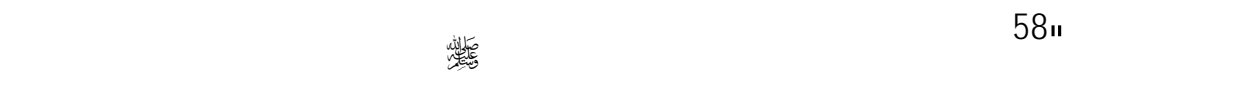

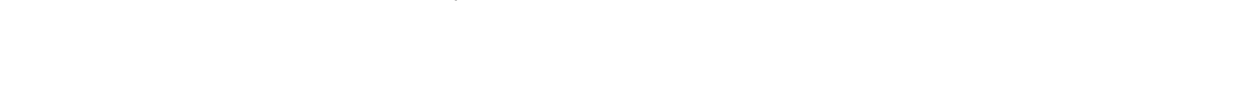

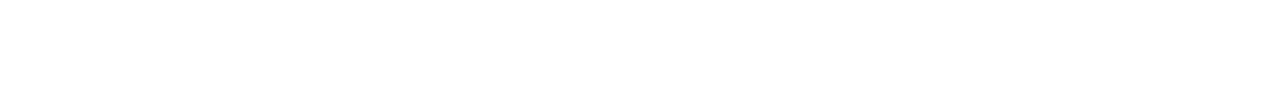
界

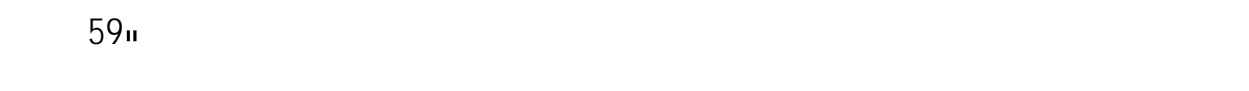

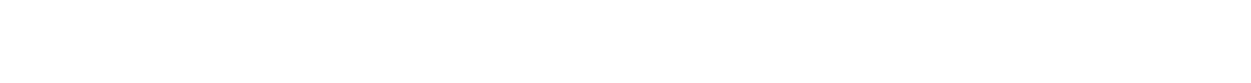

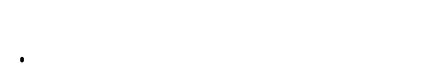

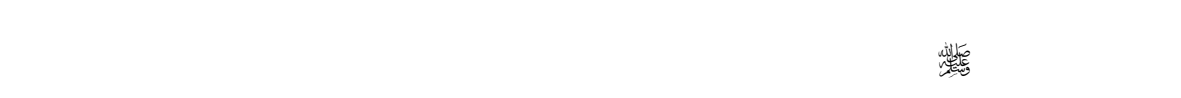

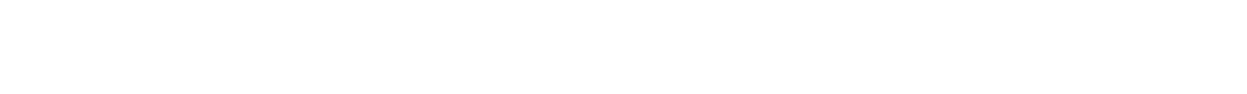

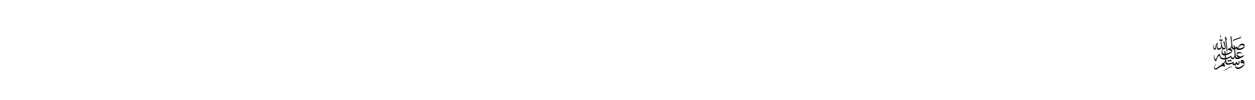

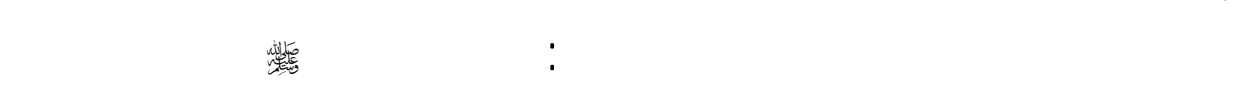

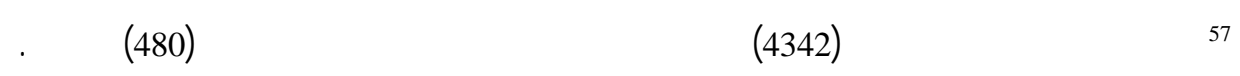

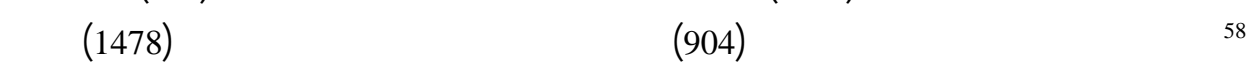
داود، السنن، كنب الصلاة (1178).

59 النسائي، المنن المغرى، كتلب الكسوف (1485)، ولن مابة، السن، كنل إلهلة الصلاة (1262). 


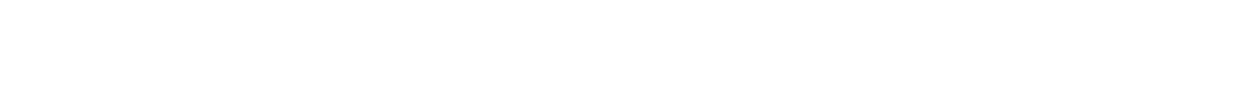

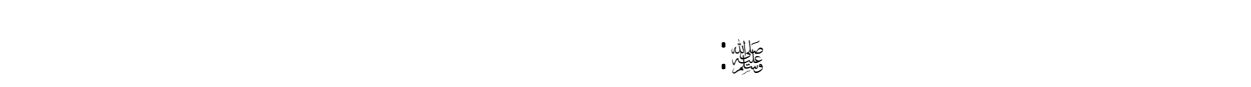

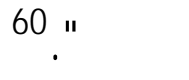

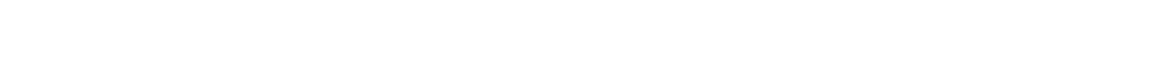

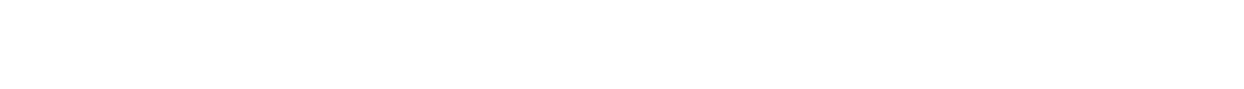

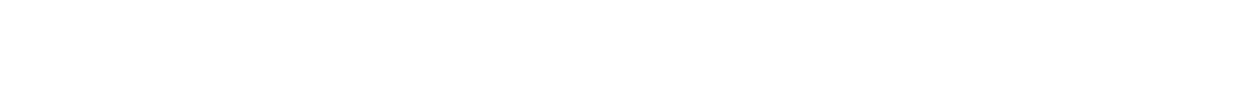

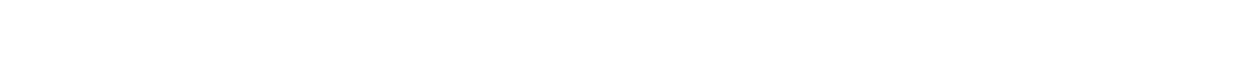

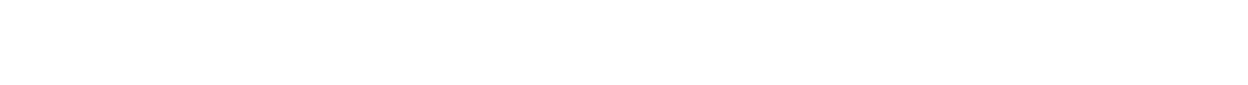

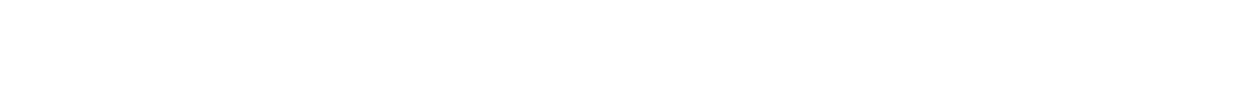

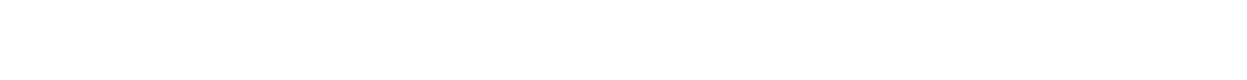

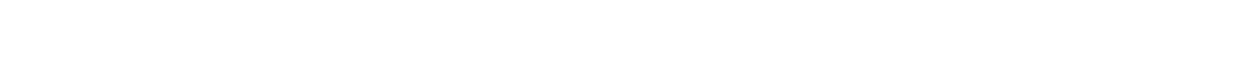

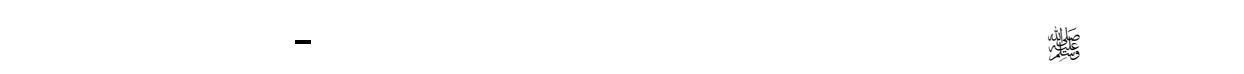

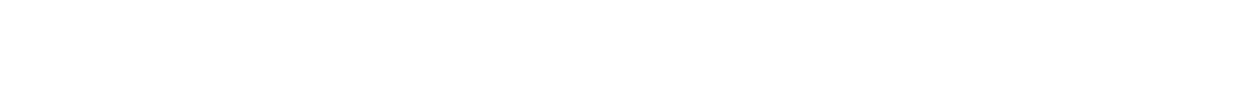

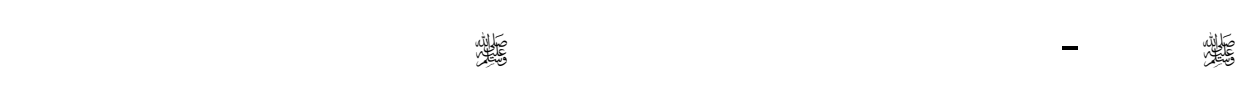

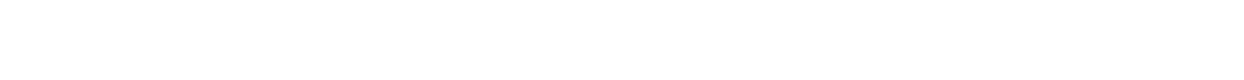

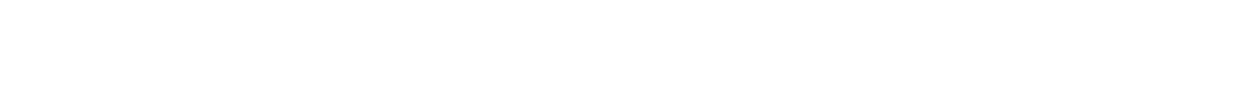

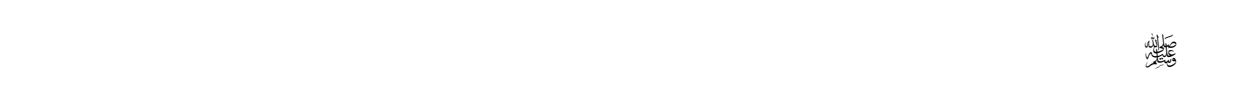
وليس لأحدقصية خلصة لنع الغزمن من قله.

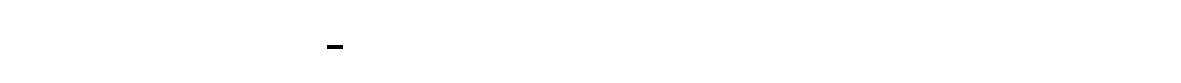

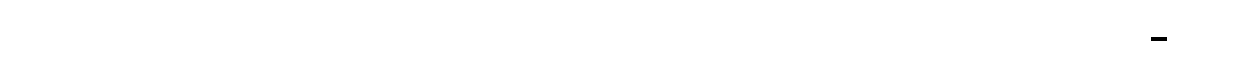




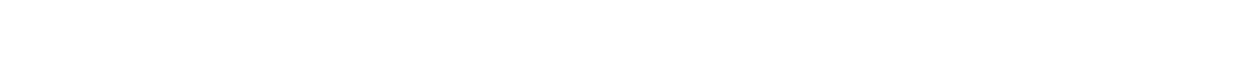

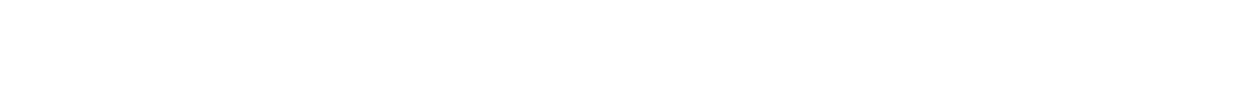

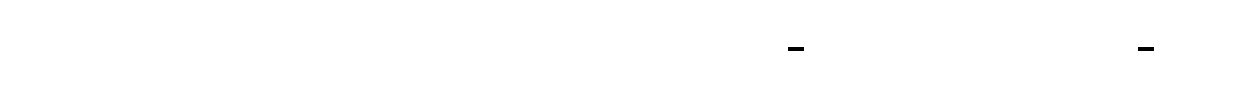

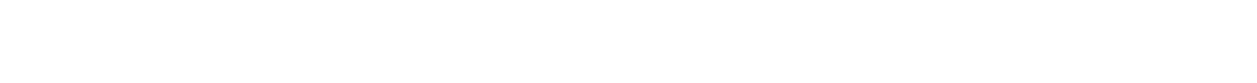

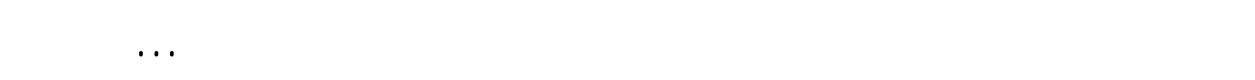

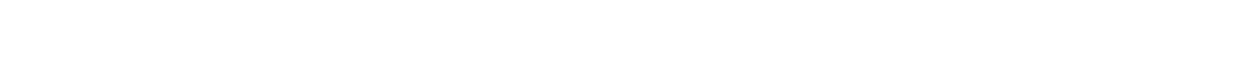

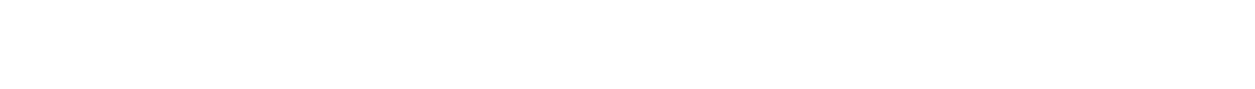

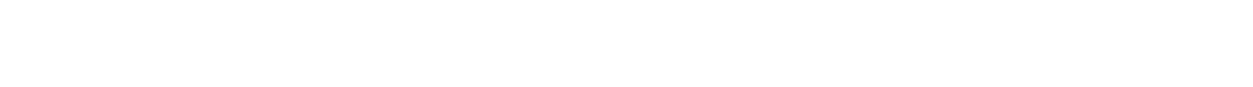
أرجولن يتسع الصرحلهة التساؤلات وهي:

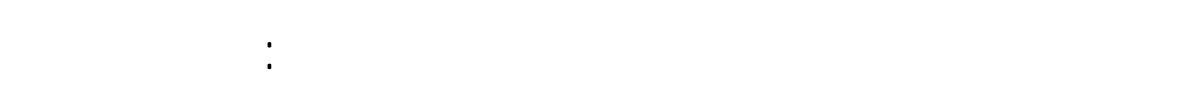

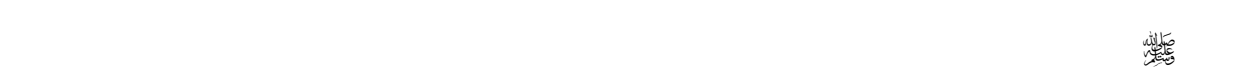

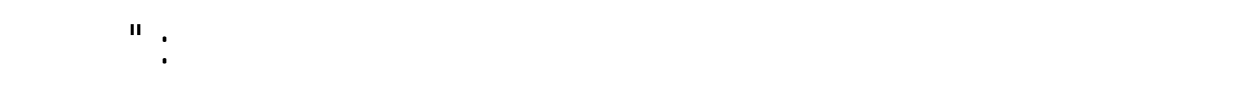

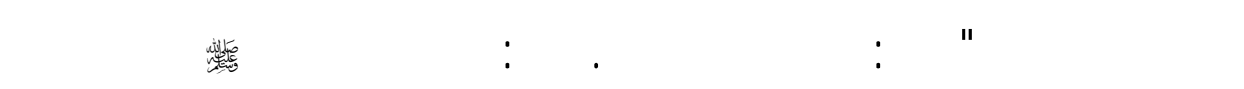

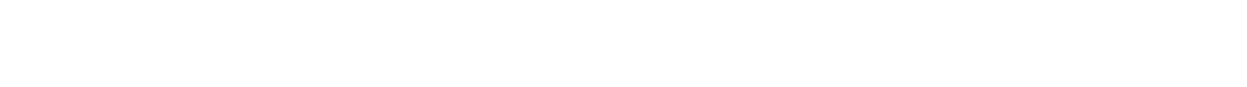

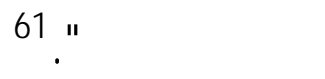

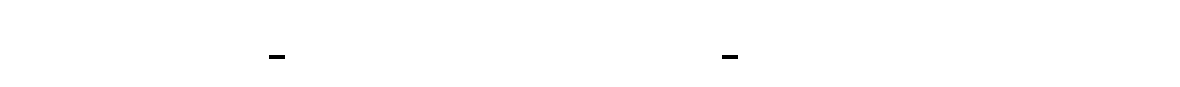

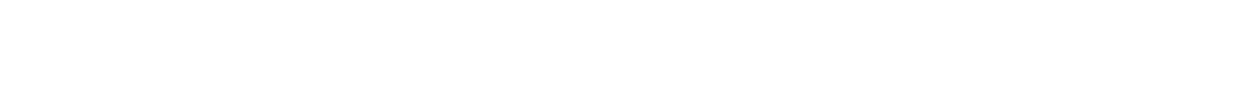
خواتيمسورة القرة؟!

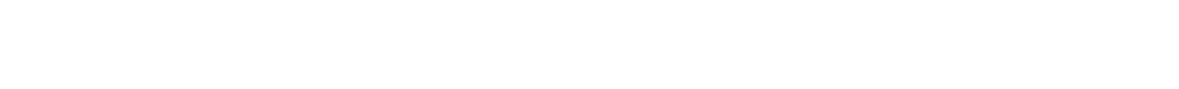

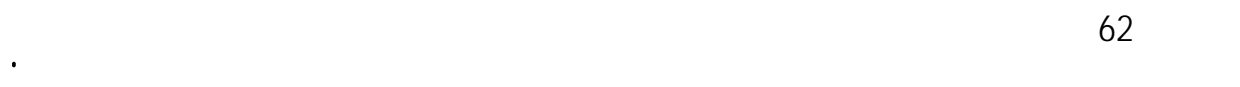

(173)

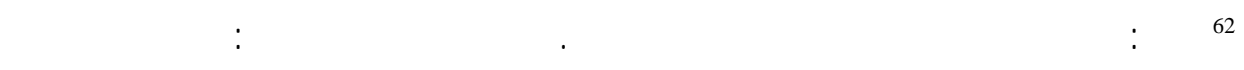
985 ه، (112/3-1169). 
183 [وث ورلسلت

قواعد نقد الـ| الكتب والسة

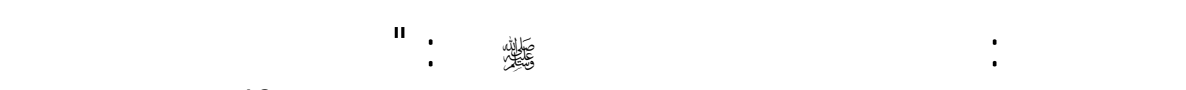

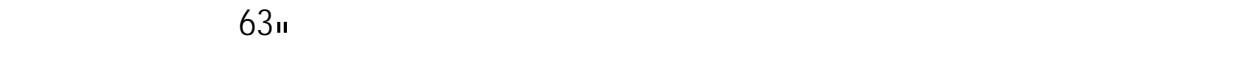

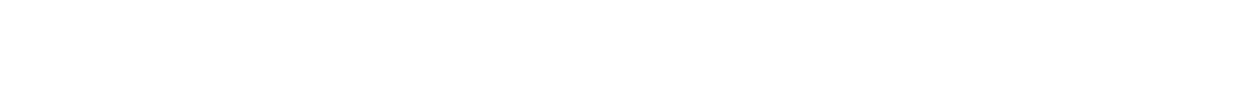

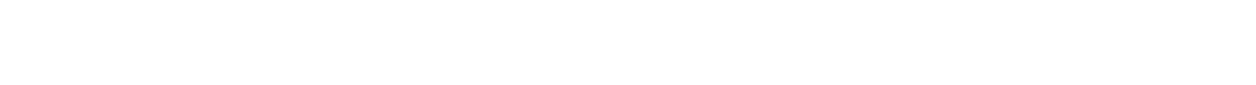

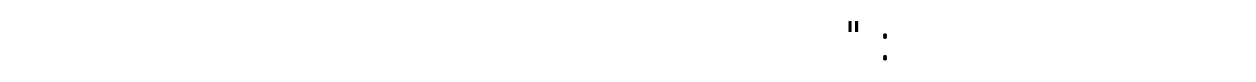

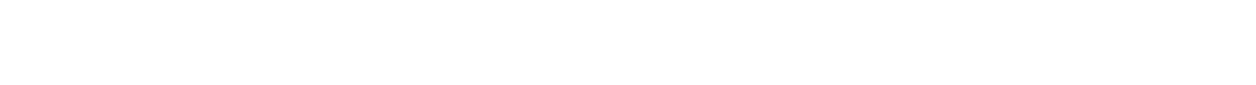

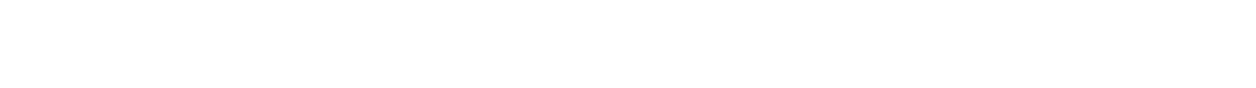

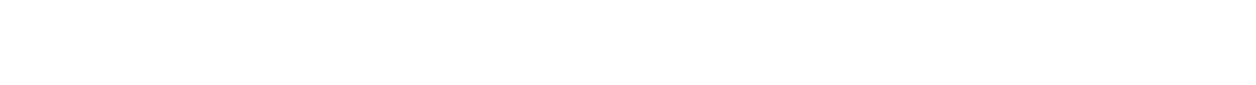

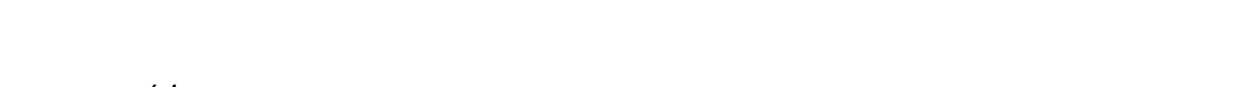

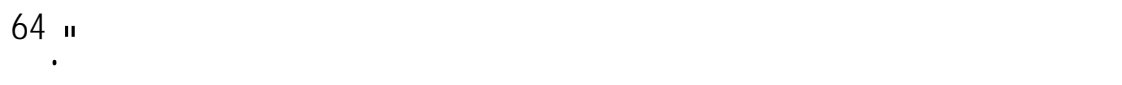

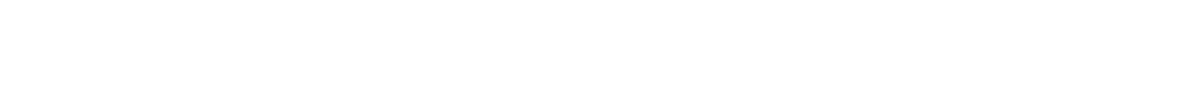

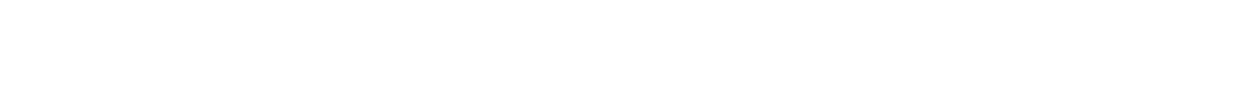

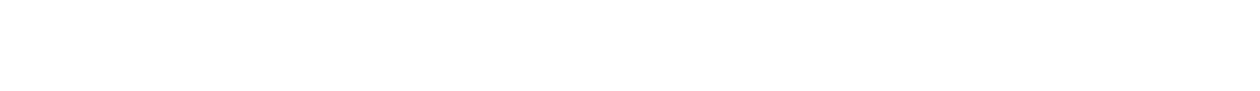

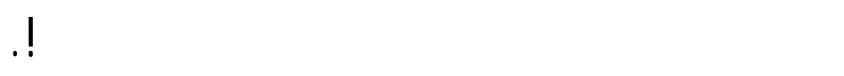

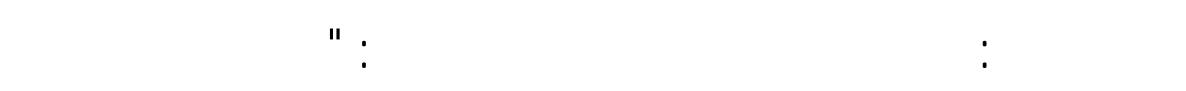

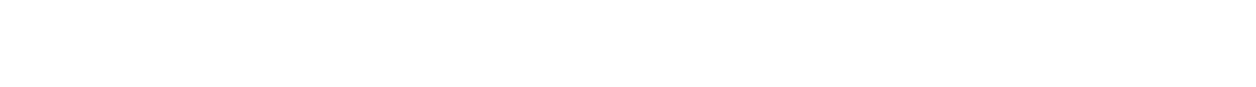

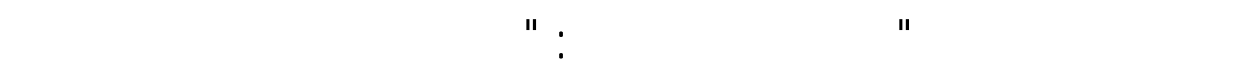

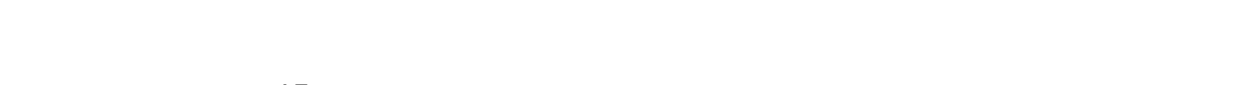

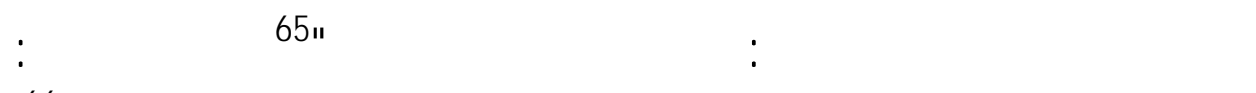

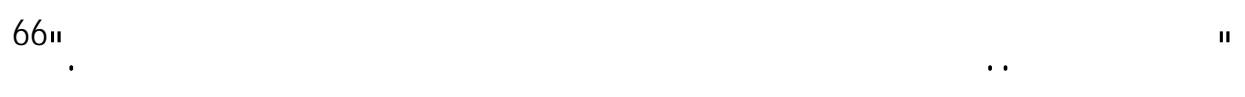

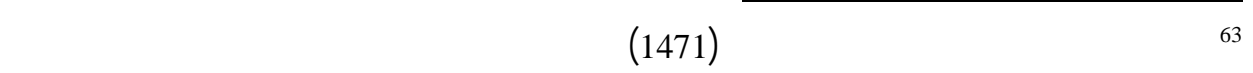

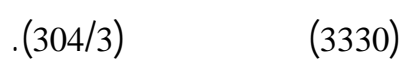

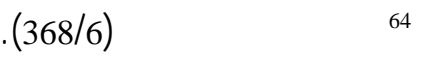

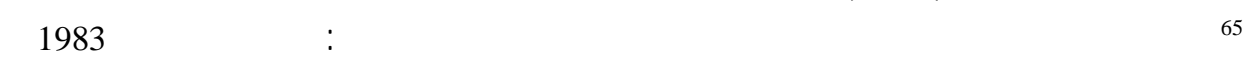
ط2، (149/3). 66 لن حجر،فتح لبادي (1450/2). 


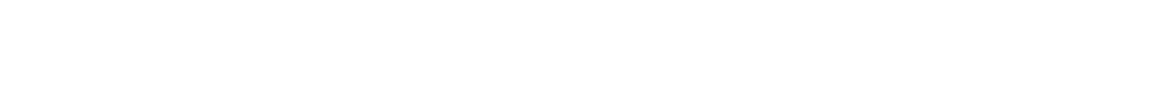

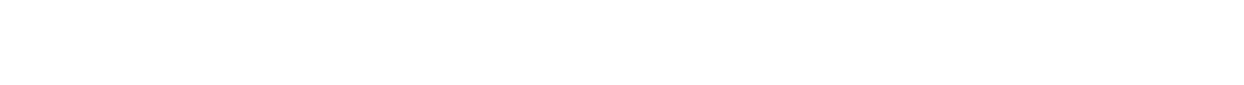


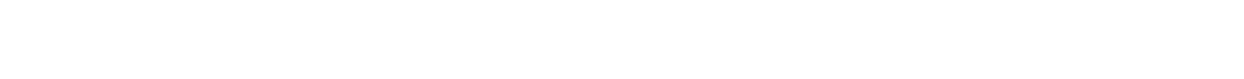

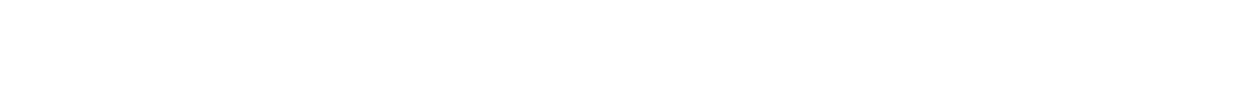
فما بل بقية أيلم الطهر؟

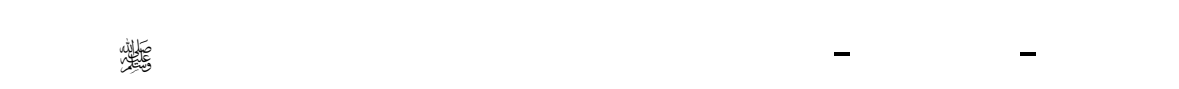

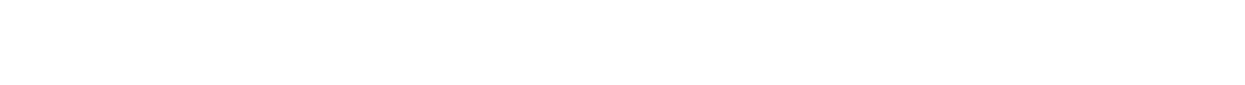

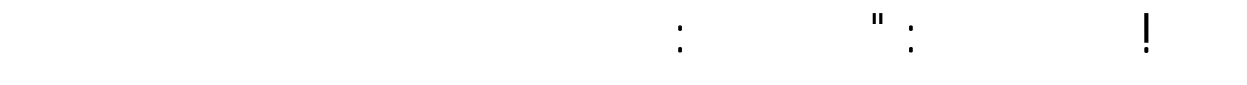

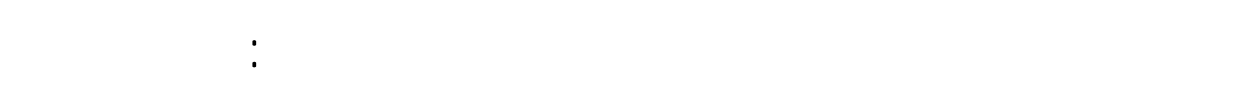

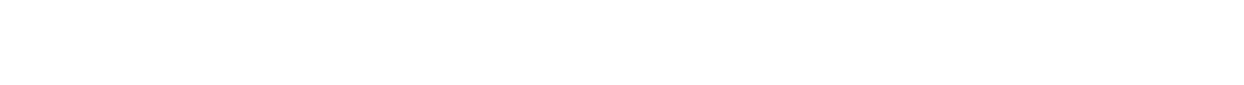

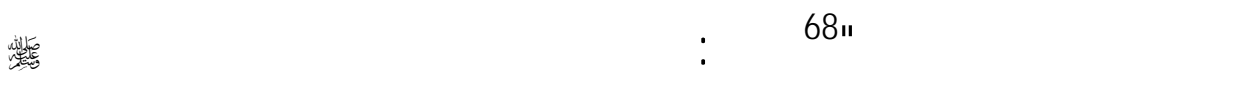

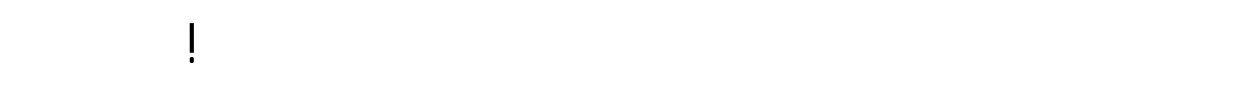

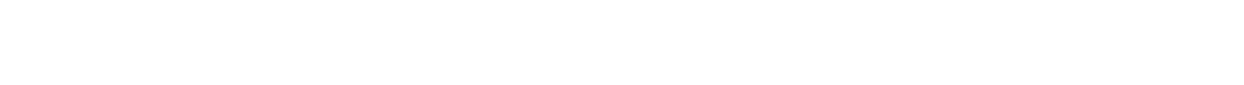

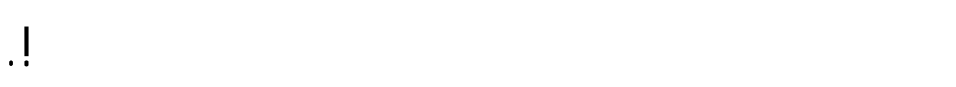

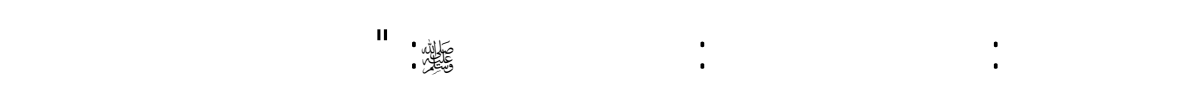

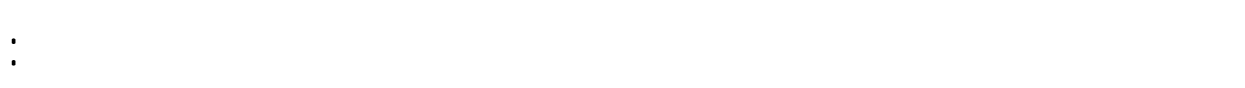

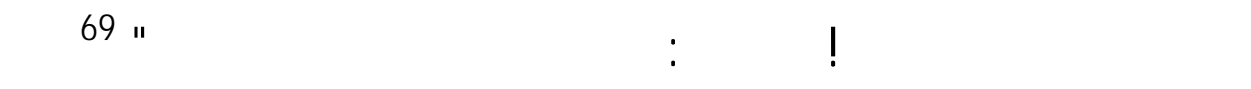

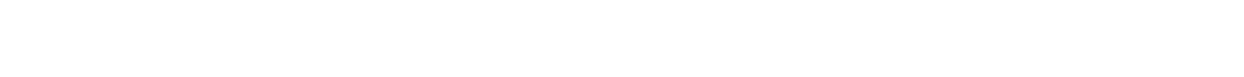

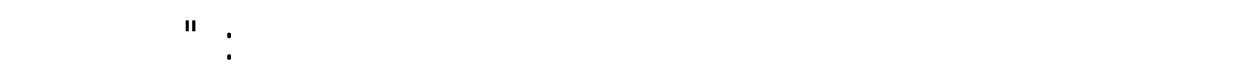

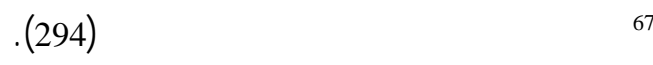

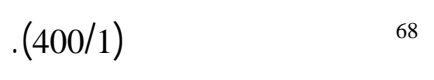

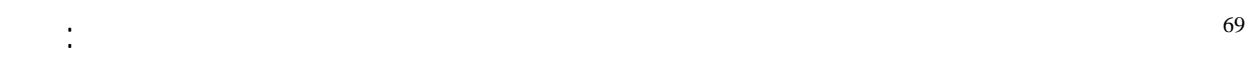

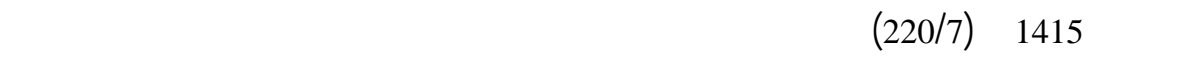

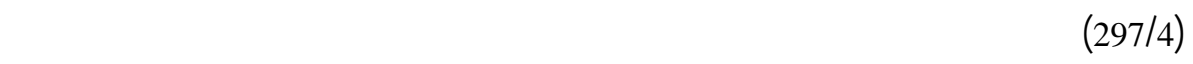

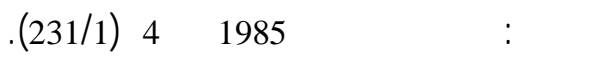




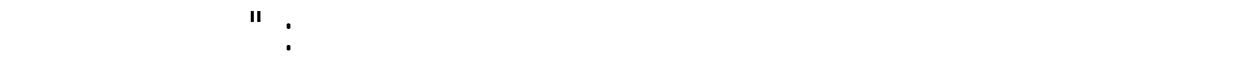

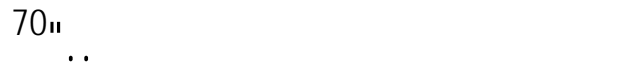

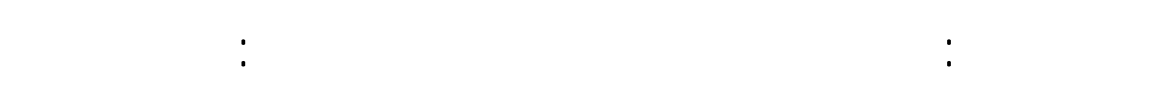

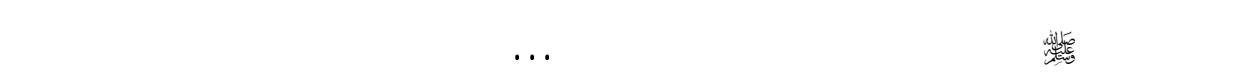

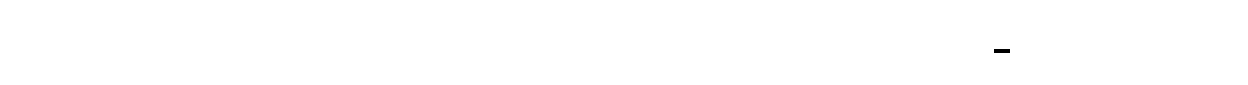

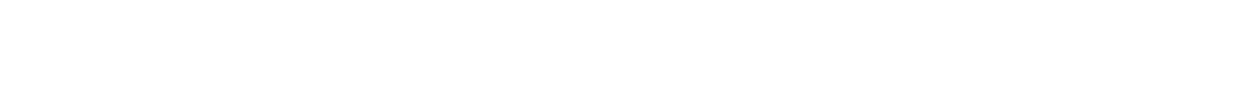

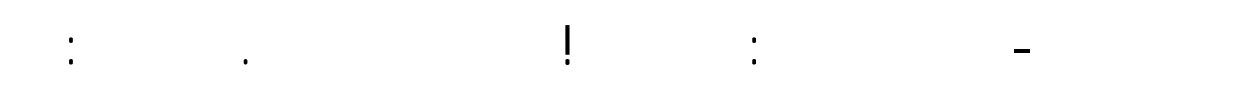

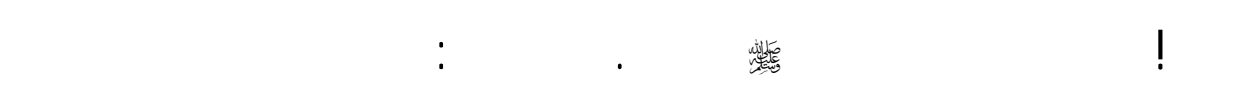
:

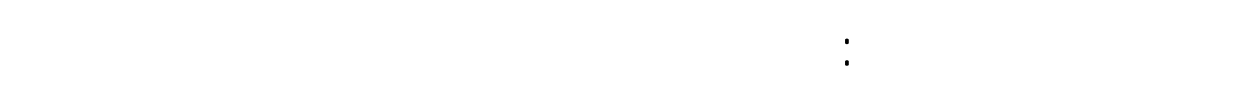

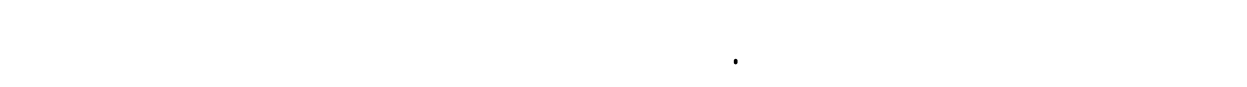

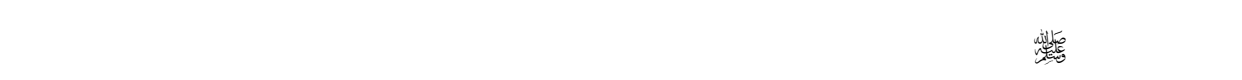

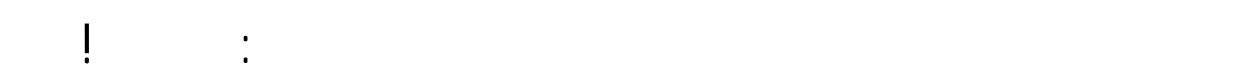
国期 71.

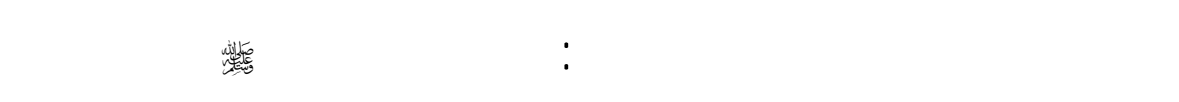

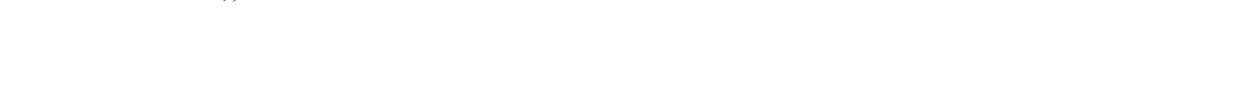

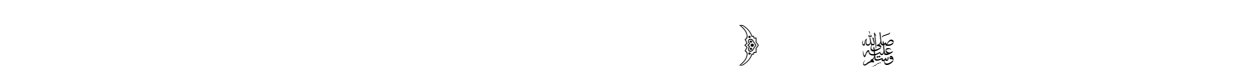

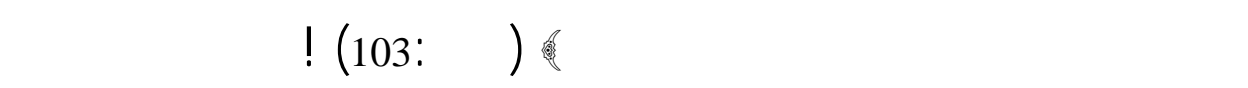

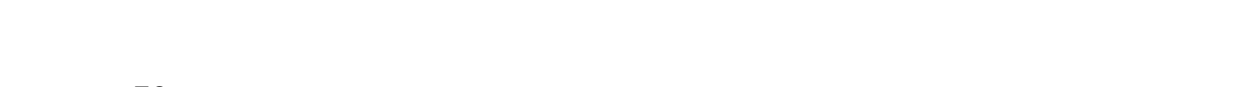

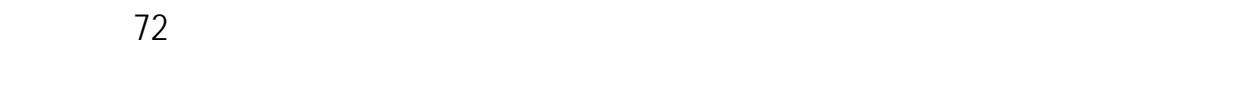

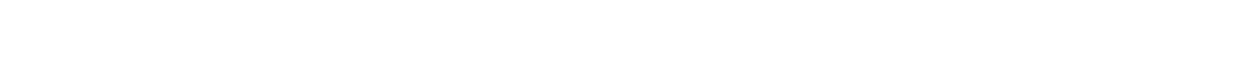

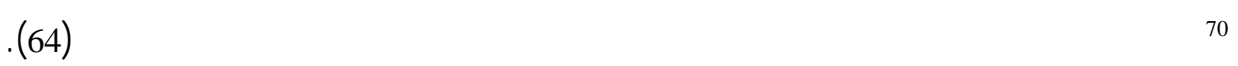

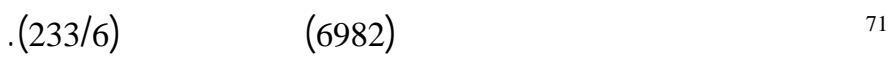
الظر: لن حجر،فتح الباري (27/1). 


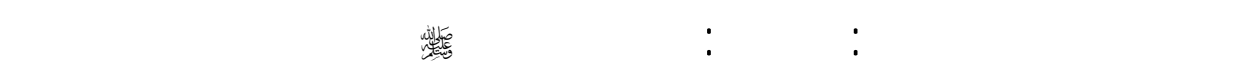

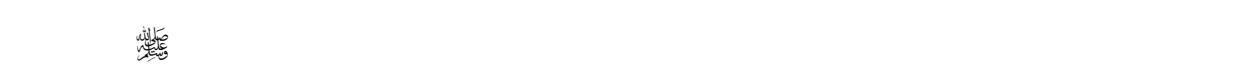

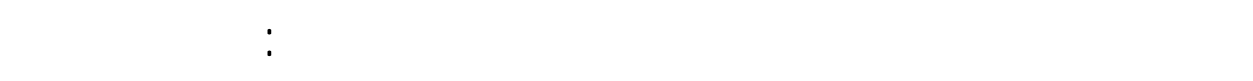

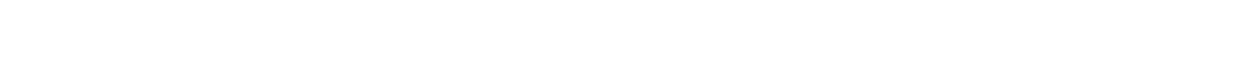

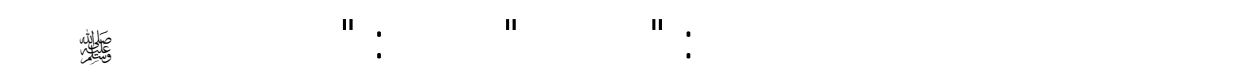

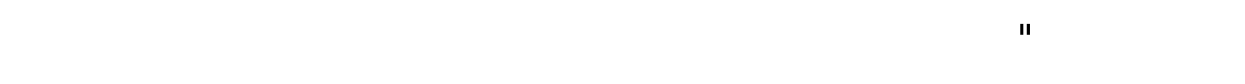

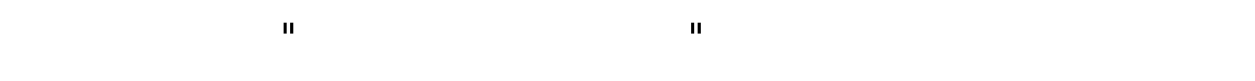

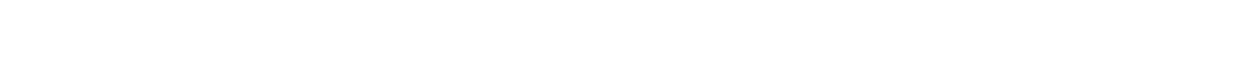

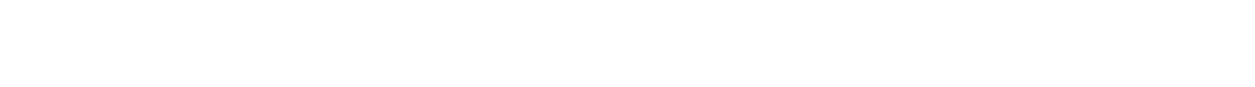

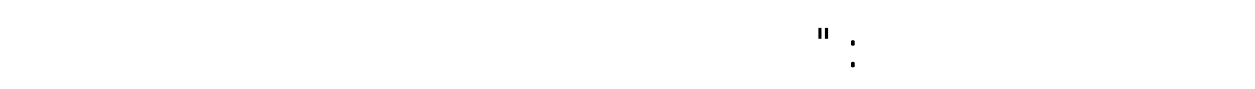

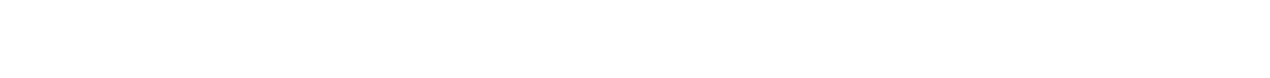

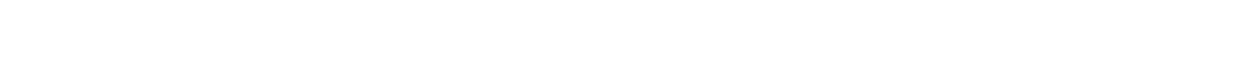

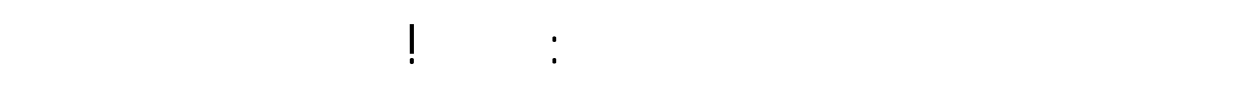

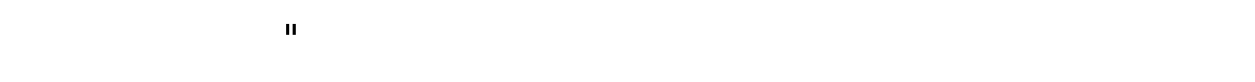

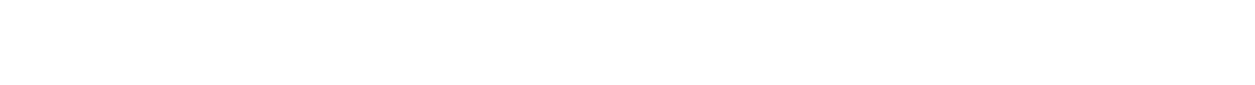

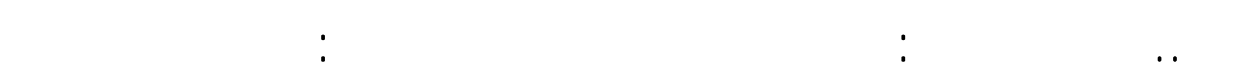

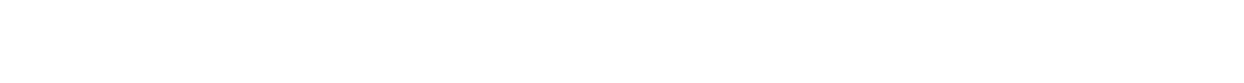

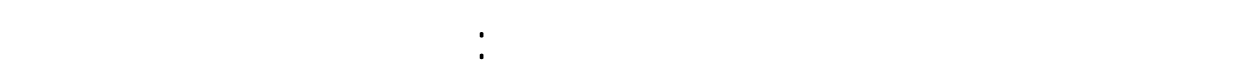

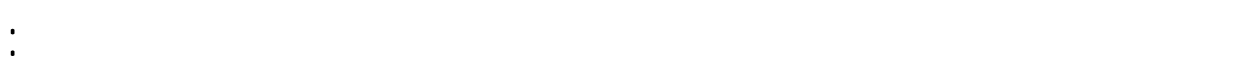

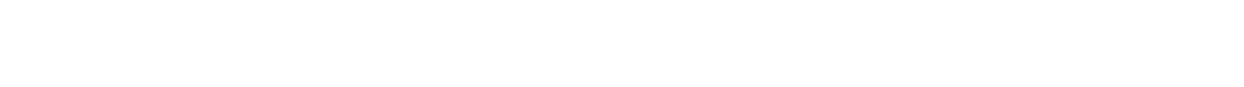

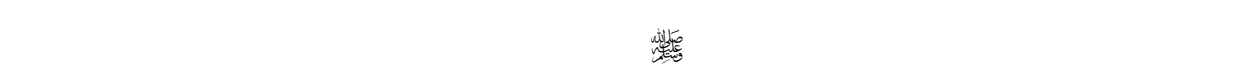

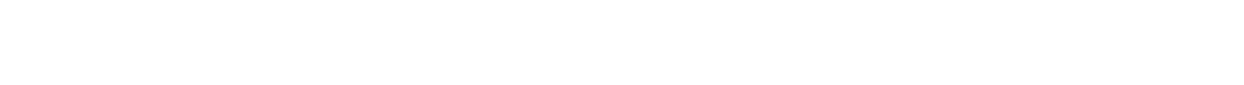

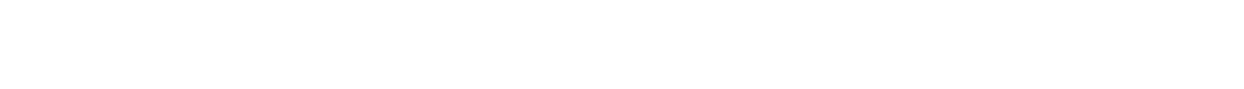

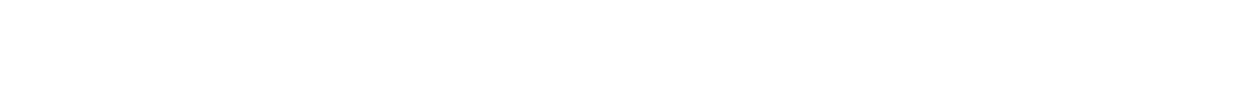

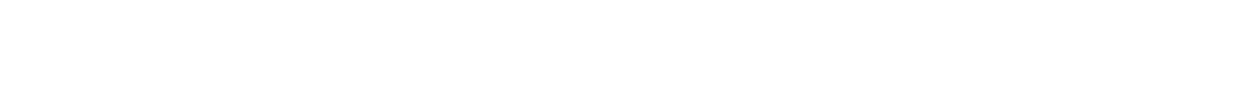


187 [مث ورلسلت

قواعد نقد الما الكنب والسة

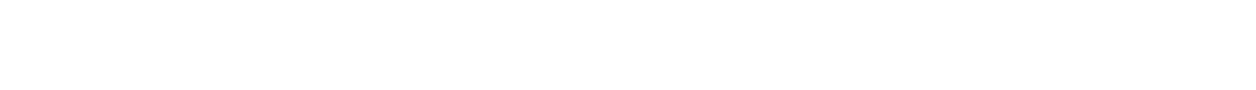

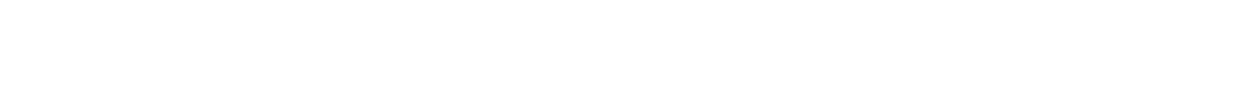

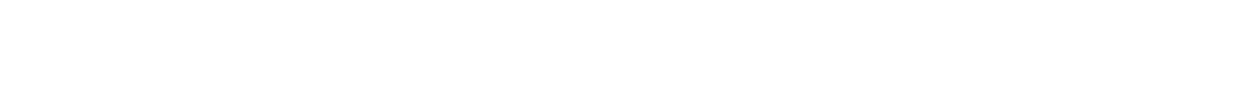

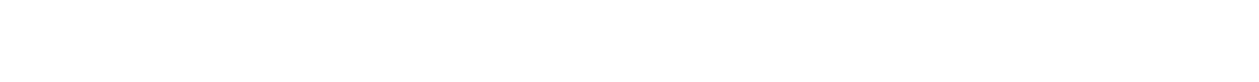

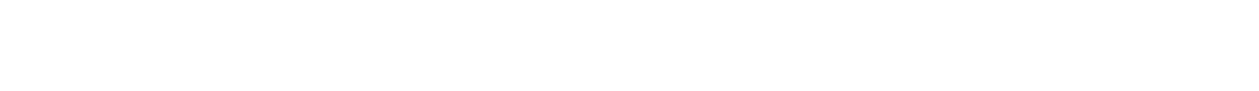

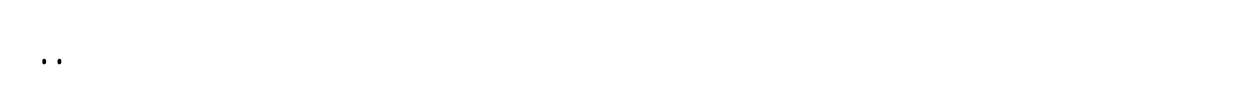

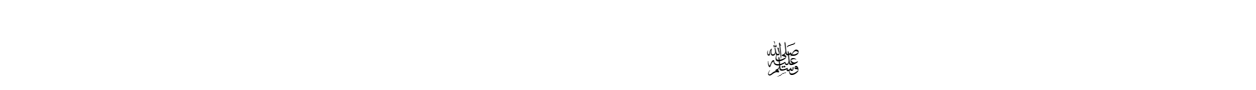

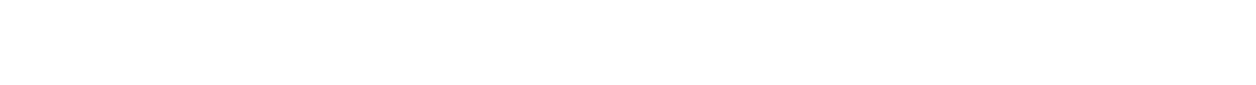

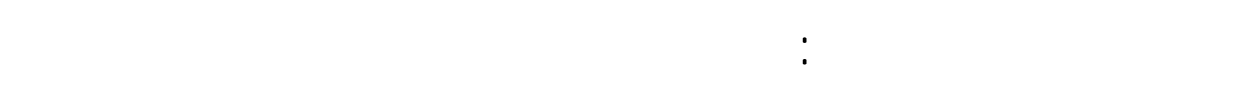

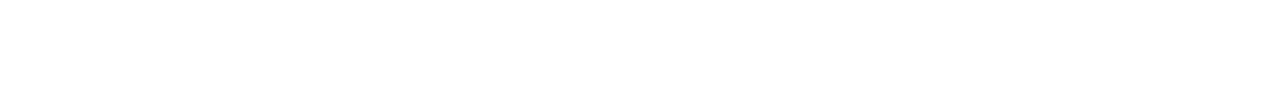

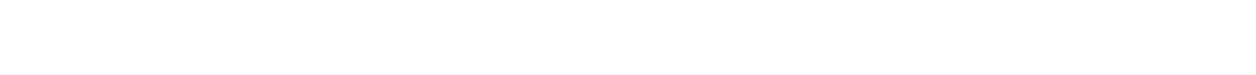

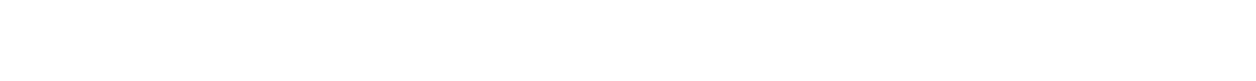

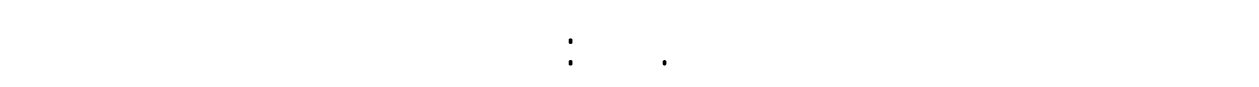

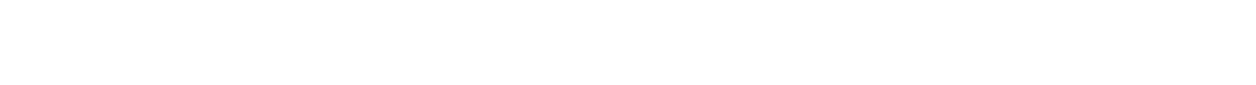

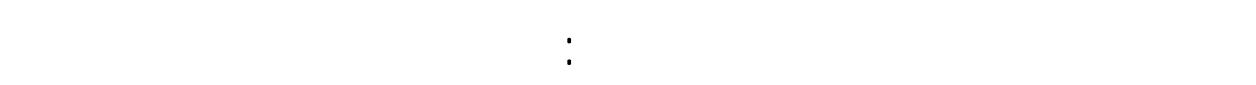

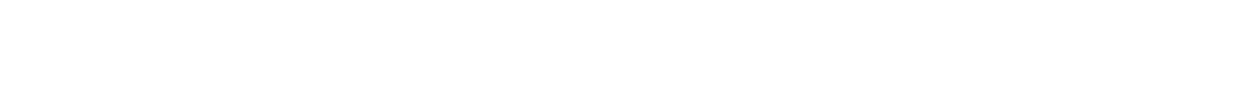

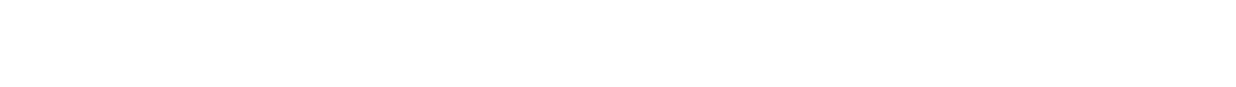

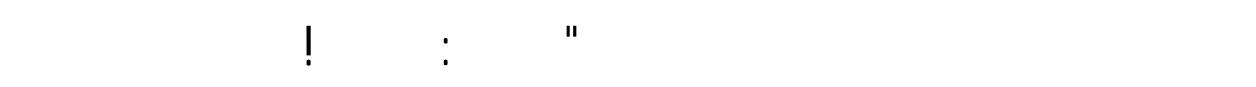

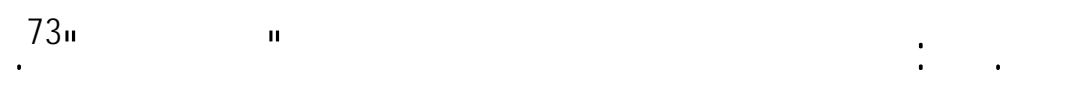

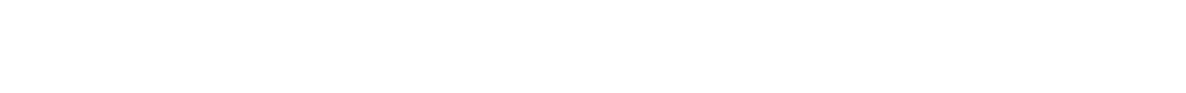

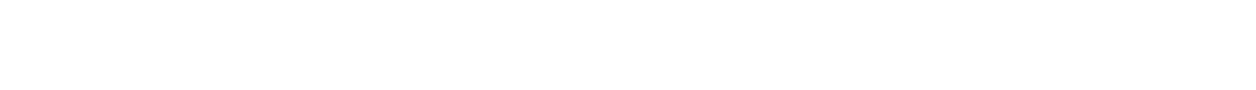

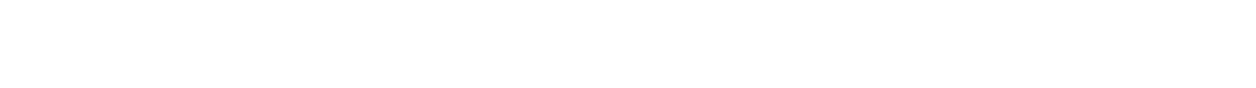

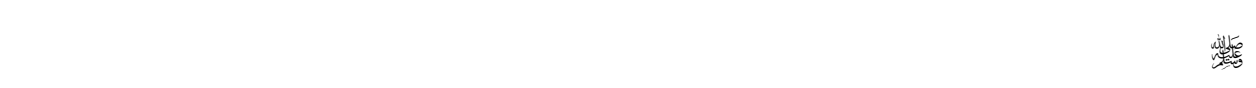

73 لن حجر،فتح الباري (360/12). 


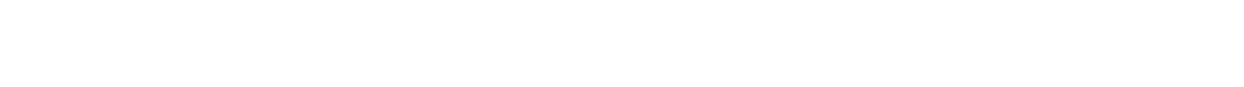

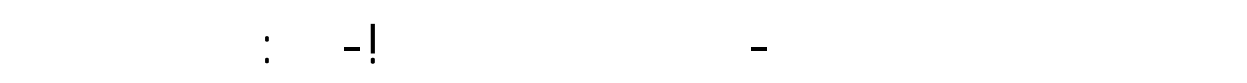

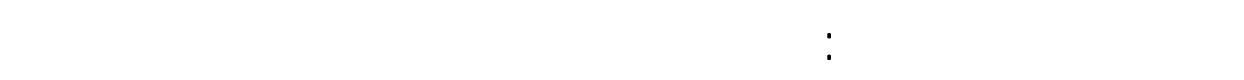

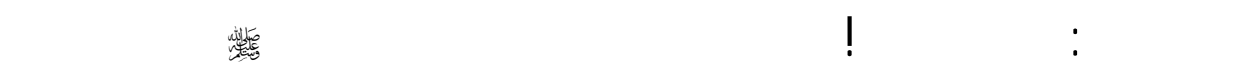

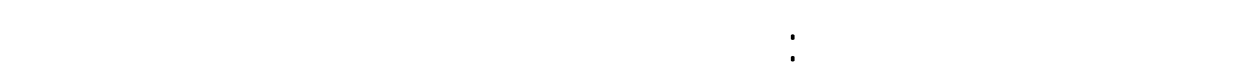

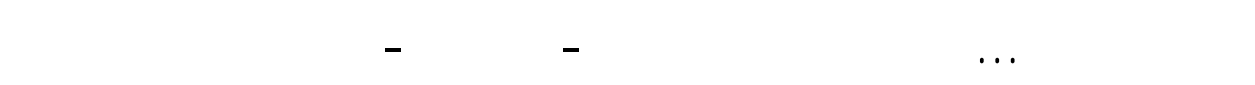

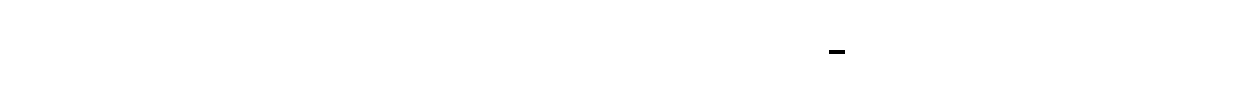

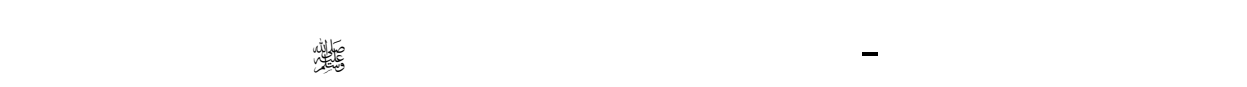

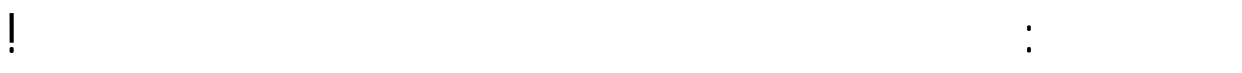

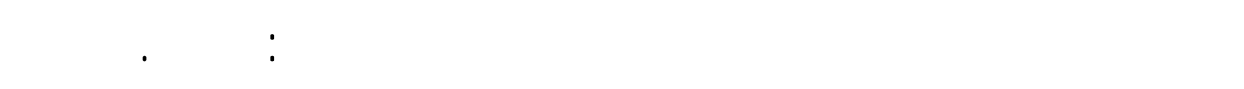

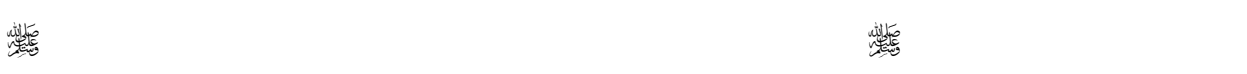

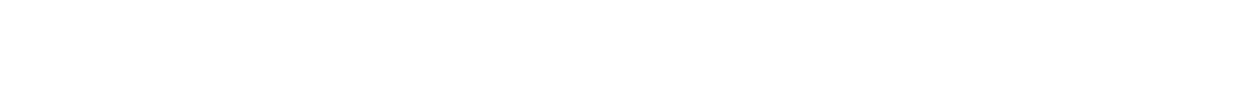

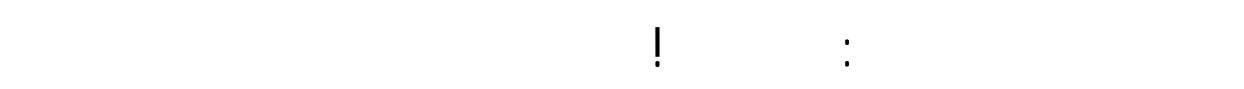

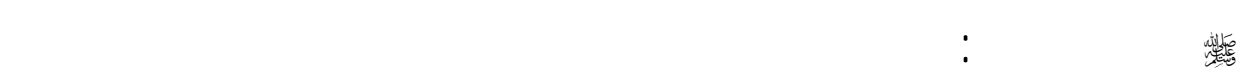

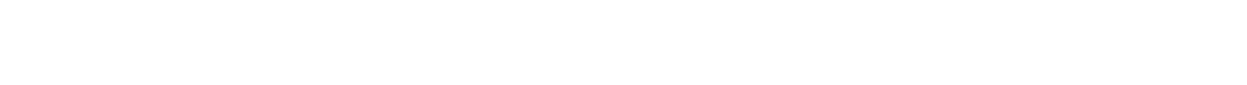

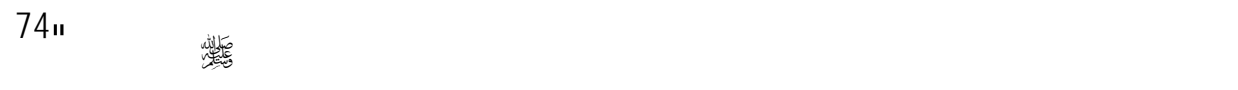

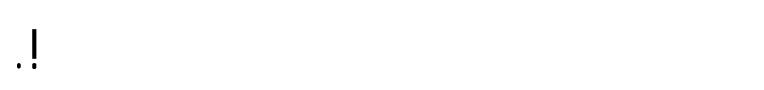

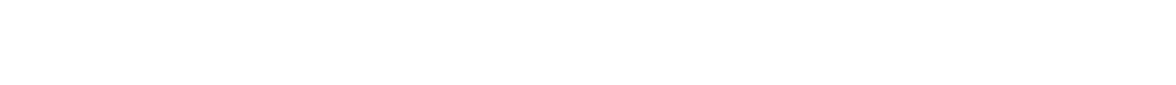

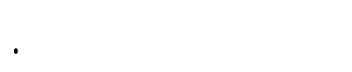

